UNIVERSIDADE DE SÃO PAULO

FACULDADE DE ODONTOLOGIA DE RIBEIRÃO PRETO

LARISSA NOGUEIRA SOARES RIBEIRO

INFLUÊNCIA DA FUMAÇA DE CIGARRO E DA APLICAÇÃO DO LASER DE BAIXA POTÊNCIA NA REMODELAÇÃO ÓSSEA.

Ribeirão Preto

2018 



\title{
INFLUÊNCIA DA FUMAÇA DE CIGARRO E DA APLICAÇÃO DO LASER DE BAIXA POTÊNCIA NA REMODELAÇÃO ÓSSEA.
}

\author{
Tese apresentada à Faculdade de Odontologia de Ribeirão \\ Preto da Universidade de São Paulo, para a obtenção do Título \\ de Doutora em Ciências. \\ Programa: Odontopediatria \\ Área de Concentração: Odontopediatria \\ Orientadora: Profa. Dra. Maria Bernadete Sasso Stuani
}

Ribeirão Preto 
AUTORIZO A REPRODUÇÃO E DIVULGAÇÃO TOTAL OU PARCIAL DESTE TRABALHO, POR QUALQUER MEIO CONVENCIONAL OU ELETRÔNICO, PARA FINS DE ESTUDO E PESQUISA, DESDE QUE CITADA A FONTE.

\section{FICHA CATALOGRÁFICA}

Ribeiro, Larissa Nogueira Soares

Influência da fumaça de cigarro e da aplicação do laser de baixa potência na remodelação óssea. Ribeiro, Larissa Nogueira Soares, Ribeirão Preto, 2018.

141p.; il.; $30 \mathrm{~cm}$

Tese de Doutorado apresentada à Faculdade de Odontologia de Ribeirão Preto da Universidade de São Paulo - Área de concentração: Odontopediatria.

Orientadora: Stuani, Maria Bernadete Sasso

1.Fumaça de cigarro. 2. Laser de baixa potência, 2. Remodelação óssea, 3. Expressão gênica. 4. Reparo ósseo. 5. Osso. 
RIBEIRO, LNS. Influência da fumaça de cigarro e da aplicação do laser de baixa potência na remodelação óssea. Tese apresentada à Faculdade de Odontologia de Ribeirão Preto da Universidade de São Paulo, para a obtenção do Título de Doutora em Ciências. Área de Concentração: Odontopediatria.

Data da defesa:

\section{BANCA EXAMINADORA}

Prof. Dr.

Instituição:

Julgamento:

Assinatura:

Prof. Dr.

Instituição:

Julgamento:

Assinatura:

Prof. Dr.

Instituição:

Julgamento:

Assinatura:

Prof. Dr.

Instituição:

Julgamento:

Assinatura:

Prof. Dr.

Instituição:

Julgamento:

Assinatura: 

DADOS CURRICULARES

\section{LARISSA NOGUEIRA SOARES RIBEIRO}

Nascimento: 7 de novembro de 1987- Uberaba- MG.

Filiação: $\quad$ Miriam Isabel Nogueira

Melânio Soares Ribeiro Neto

2007-2010: Curso de Graduação

Faculdade de Odontologia de Ribeirão Preto- Universidade de São Paulo- FORP/USP

2011-2012: Curso de Aperfeiçoamento no Atendimento Odontológico a Pacientes Especiais

Faculdade de Odontologia de Ribeirão Preto da Universidade de São Paulo

2011-2013: Curso de Especialização em Odontopediatria Associação Odontológica de Ribeirão Preto- AORP

2011-2013: $\quad$ Curso de Pós-Graduação (Mestrado) em Odontologia Área de Concentração: Odontopediatria

Faculdade de Odontologia de Ribeirão Preto da Universidade de São Paulo

Dissertação: Avaliação da Remodelação Óssea em Alvéolos Dentários, após a Aplicação do Laser de Baixa Potência. Orientadora: Profa. Dra. Maria Bernadete Sasso Stuani Bolsa: CAPES

2014-2018: Curso de Pós-Graduação (Doutorado) em Odontologia Área de Concentração: Odontopediatria

Faculdade de Odontologia de Ribeirão Preto da Universidade de São Paulo

Tese: Influência da fumaça de cigarro e da aplicação do laser de baixa potência na remodelação óssea.

Orientadora: Profa. Dra. Maria Bernadete Sasso Stuani Bolsa: CAPES 

Dedicatóra 



\section{DEDICO ESTE TRABALHO}

A Deus, por ter me dado o privilégio da vida. Que me oferece todos os dias oportunidades mágicas e coloca sempre em meu caminho pessoas iluminadas para que minha caminhada se torne mais fácil.

"Pai, ensina-me a dizer somente palavras que abençoem,

Ensina-me a ouvir apenas a Verdade,

Clareia a minha visão para que meus olhos só vejam o bem,

Mostre-me caminhos para que meus pés trilhem a fé e a esperança,

Abençoe minhas mãos para que cada gesto seja de Amor e Cura.

Senhor, ensina-me, neste momento, a calar para que eu possa ouvir-Te”.

(Parte da Oração de agradecimentos internos, Central

Crisostelar de Lira)

Ao meu Anjo da Guarda, que esta sempre comigo, me protegendo e me iluminando!

À minha mãe, Miriam Isabel Nogueira, que lutou a vida toda para que seus filhos pudessem estudar e ter uma vida melhor. Que sempre me orientou e aconselhou da melhor maneira possível e foi essencial para que eu chegasse ate aqui. Obrigada pelo amor, carinho e pela dedicação incondicional, e por lutar ao meu lado pelos meus sonhos! Te amo demais!

Ao meu namorado, Felipe Caruso Soares, que surgiu na minha vida como um presente e que me faz feliz cada dia mais! Obrigada por todos os momentos juntos, por todo apoio, pela paciência, por me ajudar a superar os obstáculos e por sempre me mostrar outro ângulo da vida! Obrigada por estar aqui nesta fase tão importante. Te amo!

À toda minha Família, principalmente meus avós, que sempre me apoiaram e me ajudaram, e principalmente a minha Madrinha, Vânia Elizabete Nogueira, que está sempre ao meu lado com todo seu amor, dedicação e carinho. Amo você manhá! 
Ao meu irmão, Rodolfo Nogueira Soares Ribeiro, que foi sempre um exemplo pra mim e que também teve participação em todas as minhas conquistas! Te amo bozinho!

Aos meus irmãos, Caroline, Paula, Diogo e Gabriela que mesmo distantes fisicamente estão sempre torcendo por mim e me apoiando. Grata pela amizade e convívio que vem crescendo!

Ao meu pai, Melânio Soares Ribeiro Neto, obrigada pelo o amor ao seu modo e pelo seu apoio. Amo você!

À todos os meus familiares e amigos que sempre torceram por mim! 
Zgradecimentos $\boldsymbol{E}_{\text {specias }}$ 



\section{AGRADECIMENTOS ESPECIAIS}

À minha orientadora, Prof ${ }^{\mathbf{a}}$. Dr ${ }^{\mathbf{a}}$. Maria Bernadete Sasso Stuani, por sempre estar presente em todos os momentos que precisei, não só na construção desde trabalho, mas na vida. Obrigada pela dedicação, pela paciência de me ensinar, pela amizade, por todo carinho e dedicação que tem por seus alunos. Sou grata pela oportunidade de aprender com a você, não só os ensinamentos científicos mais principalmente os de vida! Te amo Berna!

Aos meus amigos e companheiros de pesquisa Patrícia, Gabriel, Kelly, Elaine e Paula, por compartilharem comigo dias de aprendizado e descobertas. Obrigada por toda ajuda, companheirismo, risas e pela amizade de vocês. Grata por ter tido a oportunidade de trabalhar com vocês!

Ás minhas amigas, Larissa Gabrielle, Mariana D. Crivelenti, Mariana Silva e Souza, e a minha amiga e irmã, Paula Ferreira, que mesmo longe estão sempre "por perto". Vocês foram e são muito importantes na minha vida! Amo vocês! 

Agradecimentos 

AGRACEDIMENTOS

À Faculdade de Odontologia de Ribeirão Preto da Universidade de São Paulo, na pessoa da atual Diretora Profa. Dra. Léa Assed Bezerra da Silva e do Vice-Diretor Prof. Dr. Arthur Belém Novaes Júnior.

À Coordenação do Curso de Pós-Graduação da Faculdade de Odontologia de Ribeirão Preto da Universidade de São Paulo, na pessoa do Prof. Dr. Manoel Damião de Sousa Neto.

Aos Professores do Departamento de Clínica Infantil da Faculdade de Odontologia de Ribeirão Preto da Universidade de São Paulo, Prof. Dr. Adílson Tomasin, Profa. Dra. Aldevina Campos Freitas, Profa. Dra. Alexandra Mussolino de Queiroz, Profa. Dra. Andiara De Rossi Daldegan, Prof. Dr. Fábio Lourenço Romano, Prof. Dr. Fabricio Kitazono de Carvalho, Prof. Dr. José Tarcísio Lima Ferreira, Profa. Dra. Kranya Victoria Díaz Serrano, Profa. Dra. Léa Assed Bezerra da Silva, Profa. Dra. Maria da Conceição Pereira Saraiva, Profa. Dra. Maria Cristina Borsatto, Profa. Dra. Mírian Aiko Nakane Matsumoto, Prof. Dr. Paulo Nelson Filho e Profa. Dra. Raquel Assed Bezerra Segato, aos Professores do Departamento de Morfologia, Estomatologia e Fisiologia da Faculdade de Odontologia de Ribeirão Preto da Universidade de São Paulo Profa. Dra. Mamie Mizusaki Iyomasa e Prof. Dr. João Paulo Madergan Issa, à Professora do Departamento de Análises Clínicas, Toxicológicas e Bromatológicas da Faculdade de Ciências Farmacêuticas de Ribeirão Preto da Universidade de São Paulo Profa. Dra. Sandra Yasuyo Fukada Alves e à Professora do Departamento de Materiais dentários e Prótese da Faculdade de Odontologia de Ribeirão Preto da Universidade de São Paulo Profa. Dra. Andréa Cândido dos Reis.

À Daniele Lucca Longo, Denise Tarnavoi, Driely Barreiros de Oliveira, Erika Calvano Kuchler, Francine Lorencetti da Silva, Francisco Wanderley Garcia de Paula e Silva, Marília Pacífico Lucisano e Priscilla Coutinho Romualdo pela amizade, ajuda, pelas boas conversas e por tornarem meus dias mais felizes. 
Aos demais pós-graduandos do Programa de Pós-Graduação em Odontopediatria pelas conversas e convivência sempre tão agradável.

À Michelli Cristina Leite Rovanholo e Nilza Letícia Magalhães pela amizade, ajuda constante e paciência!

Aos funcionários do Departamento de Clínica Infantil da Faculdade de Odontologia de Ribeirão Preto da Universidade de São Paulo, Fátima Aparecida Jacinto Daniel, Filomena Leli Placciti, Matheus Morelli Zanela, Marco Antônio dos Santos e Sr. Carmo Eurípedes Terra Barretto e aos funcionários do Centro de Formação de Recursos Humanos no Atendimento Odontológico a Pacientes Especiais Carolina Paes Torres Mantovani, Fátima Aparecida Rizoli e Benedita Viana Rodrigues pela amizade e atenção que sempre manifestaram!

Aos funcionários do Biotério da Faculdade de Odontologia de Ribeirão Preto da Universidade de São Paulo, Aline Aparecida Ferraresi Tiballi, Antonio Sérgio Aparecido Mesca e Antônio Masssaro pela amizade, boa convivência, ajuda, disponibilidade e pelos cuidados prestados aos animais durante todo o período experimental desta pesquisa. Vocês foram muito importantes para o andamento desta minha pesquisa!

Aos funcionários da Seção de Pós-Graduação da Faculdade de Odontologia de Ribeirão Preto da Universidade de São Paulo, Mary Possani Carmessano e Carlos Feitosa dos Santos pela cordialidade e atenção.

À Rose, pela atenção e alegria de sempre. Obrigada pela valiosa ajuda nessa reta final.

À Coordenação de Aperfeiçoamento de Pessoal de Nível Superior (CAPES) pela bolsa concedida. 
Aos Professores da Banca, pela atenção dispensada na leitura desta dissertação.

A todos aqueles que não foram citados, mas contribuíram de alguma forma deste momento em minha vida. Muito obrigada! 

Resumo 



\section{RESUMO}

Ribeiro, LNS. Influência da fumaça de cigarro e da aplicação do laser de baixa potência na remodelação óssea. (Tese). Ribeirão Preto: Faculdade de Odontologia de Ribeirão Preto da Universidade de São Paulo, Ribeirão Preto; 2018.

Introdução: Os efeitos nocivos da fumaça de cigarro (FC) não se limitam apenas ao organismo do indivíduo fumante. A nicotina, devido aos seus efeitos tóxicos, provoca alterações graves no metabolismo ósseo, podendo prejudicar a reparação óssea alveolar. A terapia com laser de baixa potência (LBP) apresenta efeitos antiinflamatórios e analgésicos além de modular a reparação tecidual, acelerando a cicatrização e melhorando o processo de reparo ósseo. Objetivo: O objetivo do presente estudo in vivo foi avaliar o efeito da irradiação com LBP no processo de remodelação óssea após a extração dentária em ratos submetidos à fumaça de cigarro. Material e Métodos: Um total de 144 ratos Wistar foram distribuídos aleatoriamente nos seguintes grupos: Grupo Controle $(n=36)$ animais com extração dentária (Ext); Grupo Experimental I ( $n=36)$ animais que tiveram extração dentária (Ext) e aplicação do LBP nos três primeiros dias $\left(54 \mathrm{~J} / \mathrm{cm}^{2}\right.$ por dia); Grupo Experimental II $(n=36)$ animais com extração dentária (Ext) e expostos à fumaça de cigarro (FC). Grupo Experimental III $(n=36)$ animais com Ext + LBP+ FC. Os animais foram sacrificados nos períodos de 3, 7 e 14 dias após o procedimento de extração dentária, sendo que em cada grupo 18 animais foram destinados para análise da expressão gênica (RT-PCR) e 18 animais para exames histológicos. Foram avaliadas: 1) porcentagem de formação óssea no interior do alvéolo, 2) mudanças na expressão gênica de Rank, Rank-I, Opg, Onc; Occ, Opn, Bmp-2 e $B s p$. Os resultados obtidos foram submetidos à análise estatística através do teste ANOVA e o pós-teste de Bonferroni $(p<0.05)$. Resultados: Observou-se que os alvéolos do Grupo Exp I apresentaram processo de reparo mais avançado quando comparados ao Grupo Controle, caracterizado pela formação óssea mais precoce e mais intensa e pela maior expressão dos genes relacionados à remodelação óssea. O Grupo Exp II foi o que teve o pior resultado, mostrando que a fumaça de cigarro interfere negativamente no processo de reparo ósseo. No Grupo Exp III, houve uma melhora na ossificação e na expressão gênica, mostrando que o LBP pode influenciar positivamente a formação óssea. Conclusão: A utilização do LBP acelerou o processo de formação óssea durante as fases iniciais do experimento, 
embora nos períodos finais não houve diferença no processo de ossificação, e a FC interferiu negativamente no processo de remodelação óssea durante todo o período experimental.

Palavras-chave: Fumaça de cigarro, laser de baixa potência, remodelação óssea, expressão gênica, reparo ósseo, osso. 
Abstract 



\begin{abstract}
Ribeiro, LNS. The effect of cigarette smokimg and low-level laser irradiation on bone regeneration. (Thesis). Ribeirão Preto: Dentistry School of São Paulo University, Ribeirão Preto, Brazil; 2018.
\end{abstract}

Introduction:The harmful effects of cigarette smoke (CS) are not limited only to the body of the smoker. Nicotine, due to its toxic effects, causes serious alterations in the bone metabolism, which may impair alveolar bone repair. Low level laser therapy (LLLT) has anti-inflammatory and analgesic effects beyond modulating tissue repair, accelerating the healing and improving the bone healing process. Objective: The objective of the present in vivo study was to evaluate the effect of LLLT irradiation in the process of bone remodeling after dental extraction in rats submitted to cigarette smoke. Material and Methods: A total of one hundred and forty-four Wistar rats were randomly divided into four groups: Control Group $(n=36)$ animals with dental extraction (Ext), Experimental Group I $(n=36)$ animals that had dental extraction (Ext) and application of LLLT in the first three days (54 J / cm2 per day); Experimental Group II $(n=36)$ animals with dental extraction (Ext) and exposed to cigarette smoke (CS). Experimental Group III $(n=36)$ animals with Ext + LLLT + CS. The animals were sacrificed at 3, 7 and 14 days after the dental extraction procedure. In each group, 18 animals were used for analysis of gene expression (RT-PCR) and 18 animals for histological examination. We evaluated: 1) percentage of bone formation inside the alveolus, 2) changes in the gene expression of Rank, Rank-I, Opg, Onc; Occ, Opn, Bmp-2 and Bsp. The results were submitted to statistical analysis using the ANOVA test and the Bonferroni post-test $(p<0.05)$. Results: It was observed that the sockets of the Exp Group I presented a more advanced repair process when compared to the Control Group, characterized by the earlier and more intense bone formation and the greater expression of the genes related to the bone remodeling. The Exp Group II was the one that had the worst result, showing that cigarette smoke interferes negatively in the process of bone repair. In the Exp Group III, there was an improvement in ossification and gene expression, showing that LLLT can positively influence bone formation. Conclusion: The use of LLLT accelerated the bone formation process during the initial phases of the experiment, although in the final periods there was no difference in the 
ossification process, and the CS interfered negatively in the process of bone remodeling throughout all the experimental period.

Keywords: Cigarette smoke, low-power laser, bone remodeling, gene expression, bone repair, bone. 
Lista de Figuras 



\section{LISTA DE FIGURAS}

Figura 1: (A) Figura mostrando o procedimento de extração do primeiro molar superior direito e (B) alvéolo após a extração dentária.

Figura 2: Desenho esquemático representando o mecanismo de exposição à fumaça. Observa-se a câmara 1 onde os cigarros foram posicionados e a câmara 2, onde os animais permaneceram durante a exposição à fumaça de cigarro.

Figura 3: Câmara de exposição à fumaça de cigarro

Figura 4: Foto ilustrativa de um corte histológico onde é calculado a área do alvéolo (limite amarelo) e a área de osso neoformado (limites vermelhos) utilizando o ImageJ.

Figura 5: Fotomicrografias do Grupo Controle de 3, 7 e 14 dias pós extração dentária: TO - tecido ósseo, LP - ligamento periodontal, TC - tecido conjuntivo, FC - fibras colágenas, * (branco) - áreas hemorrágicas, * (preto) tecido inflamatório, V - vaso sanguíneo, setas osteoclastos. Coloração de HE e Masson

Figura 6: Fotomicrografias do Grupo Exp I de 3, 7 e 14 dias pós extração dentária: TO - tecido ósseo, LP - ligamento periodontal, TC - tecido conjuntivo, FC - fibras colágenas, * (branco) - áreas hemorrágicas, * (preto) tecido inflamatório, V - vaso sanguíneo, setas osteoclastos. Coloração de HE e Masson

Figura 7: Fotomicrografias do Grupo Exp II de 3, 7 e 14 dias pós extração dentária: TO - tecido ósseo, LP - ligamento periodontal, TC - tecido conjuntivo, FC - fibras colágenas, * (branco) - áreas hemorrágicas, * (preto) tecido inflamatório, V - vaso sanguíneo, setas osteoclastos. Coloração de HE e Masson.

Figura 8: Fotomicrografias do Grupo Exp III de 3, 7 e 14 dias pós extração dentária: TO - tecido ósseo, LP - ligamento periodontal, TC - tecido conjuntivo, FC - fibras colágenas, * (branco) - áreas hemorrágicas, * (preto) tecido inflamatório, V - vaso sanguíneo, setas osteoclastos. Coloração de HE e Masson

Expressão da percentagem média e desvio padrão da formação

Figura 9: óssea no Grupo Controle e Experimentais. Os dados correspondem a 14 dias de experimento. ${ }^{*} \mathrm{p}<0,05 ;{ }^{* *} \mathrm{p}<0,01 ;{ }^{* * *} \mathrm{p}<0,001$; $p>0,05=$ não significativo. 
Figura 10: Expressão da percentagem média e desvio padrão da formação óssea nos Grupos Controle e Experimentais. Os dados correspondem a 14 dias de experimento. ${ }^{*} p<0,05 ;{ }^{* *} p<0,01$; ${ }^{* * *} p<0,001 ; p>0,05=$ não significativo.

Figura 11: (A) Expressão do RNAm do gene Bmp2 nos diferentes grupos em relação ao Grupo Controle e (B) Expressão do RNAm do gene Bmp2 nos diferentes grupos experimentais. Os gráficos mostram a média, desvio padrão e ${ }^{*} \mathrm{p}<0,05 ;{ }^{* *} \mathrm{p}<0,01 ;{ }^{* * *} \mathrm{p}<0,001$

Figura 12: (A) Expressão do RNAm do gene Bsp nos diferentes grupos em relação ao Grupo Controle e (B) Expressão do RNAm do gene Bsp nos diferentes grupos experimentais. Os gráficos mostram a média, desvio padrão e ${ }^{*} \mathrm{p}<0,05 ;{ }^{* *} \mathrm{p}<0,01 ;{ }^{* *} \mathrm{p}<0,001$.

Figura 13: (A) Expressão do RNAm do gene Opn nos diferentes grupos em relação ao Grupo Controle e (B) Expressão do RNAm do gene Opn nos diferentes grupos experimentais. Os gráficos mostram a média, desvio padrão e ${ }^{*} \mathrm{p}<0,05 ;{ }^{* *} \mathrm{p}<0,01 ;{ }^{* * *} \mathrm{p}<0,001$.

Figura 14: (A) Expressão do RNAm do gene Onc nos diferentes grupos em relação ao Grupo Controle e (B) Expressão do RNAm do gene Onc nos diferentes grupos experimentais. Os gráficos mostram a média, desvio padrão e ${ }^{*} p<0,05 ;{ }^{* *} p<0,01 ;{ }^{* *} p<0,001$

Figura 15: (A) Expressão do RNAm do gene Occ nos diferentes grupos em relação ao Grupo Controle e (B) Expressão do RNAm do gene Occ nos diferentes grupos experimentais. Os gráficos mostram a média, desvio padrão e ${ }^{*} \mathrm{p}<0,05 ;{ }^{* *} \mathrm{p}<0,01 ;{ }^{* * *} \mathrm{p}<0,001$.

Figura 16: (A) Expressão do RNAm do gene Rank nos diferentes grupos em relação ao Grupo Controle e (B) Expressão do RNAm do gene Rank nos diferentes grupos experimentais. Os gráficos mostram a média, desvio padrão e ${ }^{*} \mathrm{p}<0,05 ;{ }^{* *} \mathrm{p}<0,01 ;{ }^{* * *} \mathrm{p}<0,001$

Figura 17: (A) Expressão do RNAm do gene Rankl nos diferentes grupos em relação ao Grupo Controle e (B) Expressão do RNAm do gene Rankl nos diferentes grupos experimentais. Os gráficos mostram a média, desvio padrão e ${ }^{*} \mathrm{p}<0,05 ;{ }^{* *} \mathrm{p}<0,01 ;{ }^{* * *} \mathrm{p}<0,001$

Figura 18: (A) Expressão do RNAm do gene Opg nos diferentes grupos em relação ao Grupo Controle e (B) Expressão do RNAm do gene Opg nos diferentes grupos experimentais. Os gráficos mostram a média, desvio padrão e ${ }^{*} \mathrm{p}<0,05 ;{ }^{* *} \mathrm{p}<0,01 ;{ }^{* * *} \mathrm{p}<0,001$. 
Lista de Tabelas e Quadro 



\section{LISTA DE TABELAS E QUADRO}

Tabela 1: Grupos experimentais, tempos, número de animais e procedimentos propostos

Tabela 2: Grupos experimentais, tempos, número de animais e procedimentos propostos.

Tabela 3: Porcentagem média da Área de Osso Neoformado (ONF) na área do alvéolo, com comparação entre os grupos.

Quadro 1: Análise de variância (ANOVA) e teste de TUKEY dos resultados histomorfométricos, referentes à percentagem de trabéculas ósseas formadas entre o Grupo Controle, Laser de baixa potência (LBP) e Fumaça de cigarro (FC). Nível de significância estatística $(p<0,05) \ldots \ldots$. 



\section{Lista de $\mathcal{A}$ breviaturas, Siglase Simbolos}





\section{LISTA DE ABREVIATURAS, SIGLAS E SÍMBOLOS}

$\% \quad$ Expressa um valor em percentual

${ }^{\circ} \mathrm{C} \quad$ Graus centígrados (Celsius)

ANOVA Análise de Variância

AON Area de osso neoformado

AsGa Arsenieto de gálio

AsGaAl Arsenieto de gálio-alumínio

AT Área total

Bglap Gene referente à expressão de osteocalcina (OCC)

Bmp-2 Gene referente à expressão de proteína óssea morfogenética 2 (BMP-2)

BMP2 Proteína óssea morfogenética 2

BSP Sialoproteína óssea

Grupo C Grupo Controle

cDNA Ácido desoxirribonucleico complementar

CEUA Comissão de Ética no Uso de Animais

$\mathbf{c m}^{3} \quad$ Centímetros cúbicos

$\mathbf{C}_{\mathrm{T}} \quad$ Ciclo de amplificação (cycle threshold)

$\Delta \quad$ Delta

$\Delta$ CT Diferença entre CT da amostra amplificada para o gene alvo e o CT da mesma amostra amplificada para o gene de referência

$\Delta \Delta C T$ Diferença entre o $\Delta C T$ da amostra interesse e o $\Delta C T$ da amostra de referência-calibrador

cm3 Centímetros cúbicos

COBEA Colégio Brasileiro de Experimentação Animal

DEPC: Dietilpirocarbonato

DNA Ácido desoxirribonucleico

EDT Etileno-diamino-tetra-acético

FC Fumaça de cigarro

FORP-USP Faculdade de Odontologia de Ribeirão Preto da Universidade de São Paulo

G Exp Grupo Experimental

g Grama(s)

GAPDH Gliceraldeído-3-fosfato desidrogenase

HE Hematoxilina e eosina

J Joules 


\begin{tabular}{|c|c|}
\hline $\mathrm{J} / \mathrm{cm} 2$ & Joules por centímetro quadrado \\
\hline ibsp & Gene referente à expressão de sialoproteína óssea (BSP) \\
\hline Kg & Quilograma(s) \\
\hline kV & Quilovolt(s) \\
\hline Laser & $\begin{array}{l}\text { Light amplification by stimulated emission of radiation (Amplificação } \\
\text { da luz por emissão estimulada da radiação) }\end{array}$ \\
\hline LBP & Laser de baixa potência \\
\hline LLLT & Low-level laser therapy \\
\hline $\mathbf{m g} / \mathbf{k g}$ & Miligrama por quilograma \\
\hline mg & Miligrama(s) \\
\hline $\mathbf{m L}$ & Mililitro(s) \\
\hline mm & Milímetro(s) \\
\hline mm2 & Milímetro quadrado \\
\hline ng: & Nanograma(s) \\
\hline nm: & Nanômetro(s) \\
\hline OCC & Osteocalcina \\
\hline OMS & Organização Mundial da Saúde \\
\hline ONC & Osteonectina \\
\hline OPG & Osteoprotegerina \\
\hline OPN & Osteopontina \\
\hline$p$ & Valor-p \\
\hline PBS & Solução tampão fosfato salino \\
\hline pH & Potencial hidrogeniônico \\
\hline QR: & Nível de expressão gênica relativa \\
\hline qRT-PCR: & Reação de polimerase em cadeia em tempo real \\
\hline RANK & Receptor ativador do fator nuclear Kappa B \\
\hline RANK-L & Ligante do receptor ativador Kappa B \\
\hline RNA & Ácido ribonucleico \\
\hline RNAm & Ácido ribonucleico mensageiro \\
\hline$\Delta$ & Delta \\
\hline Sparc & Gene referente à expressão de osteonectina (ONC) \\
\hline Spp1 & Gene referente à expressão de osteopontina (OPN) \\
\hline Tnfsf11 & $\begin{array}{l}\text { Gene referente à expressão de ligante do receptor ativador do fator } \\
\text { nuclear kappa B (RANKL) }\end{array}$ \\
\hline
\end{tabular}

Tnfrsf11a Gene referente à expressão de receptor ativador do fator nuclear kappa B (RANK) 
Tnfrsf11b: Gene referente à expressão de osteoprotegerina (OPG)

$\mu \mathrm{L}: \quad$ Microlitro(s)

$\quad$ m: $\quad$ Micrômetro(s) 

Sumário 



\section{SUMÁRIO}

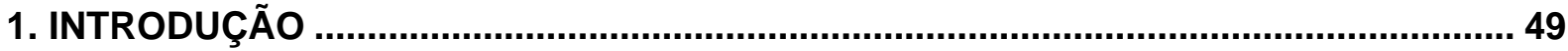

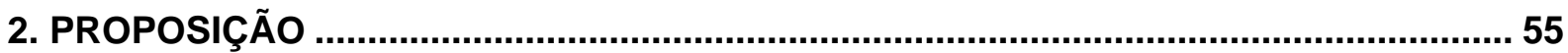

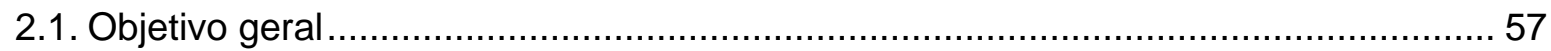

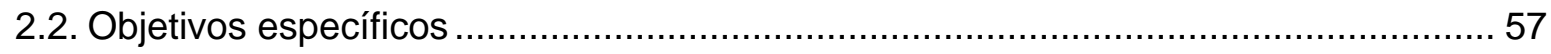

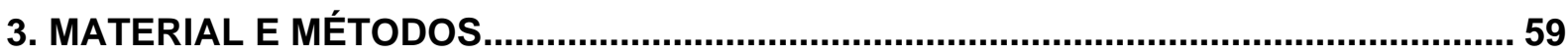

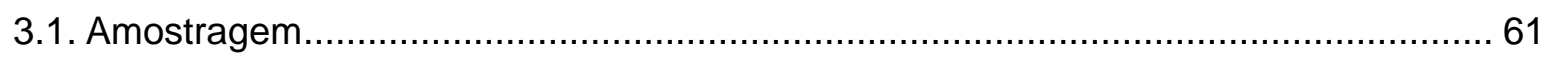

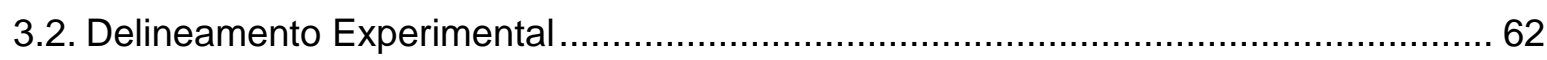

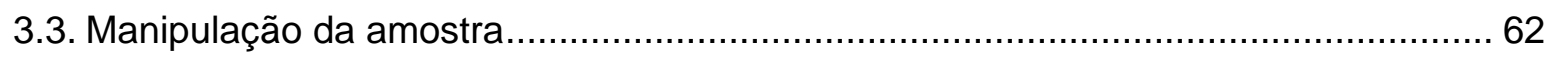

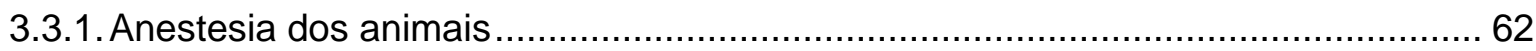

3.3.2. Exodontia do Primeiro Molar Superior Direito ..................................................... 62

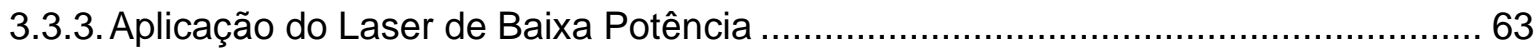

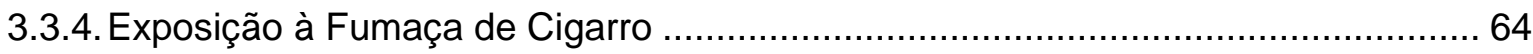

3.3.5. Eutanásia dos animais e coleta dos Espécimes................................................. 65

3.4. Preparo das peças para exame histológico ......................................................... 66

3.4.1. Coloração dos cortes para microscópio de luz ................................................ 67

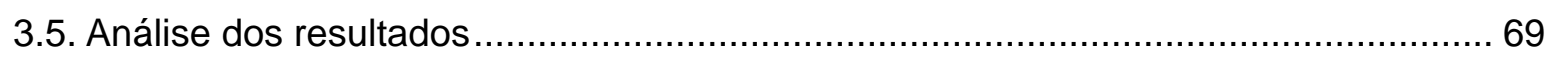

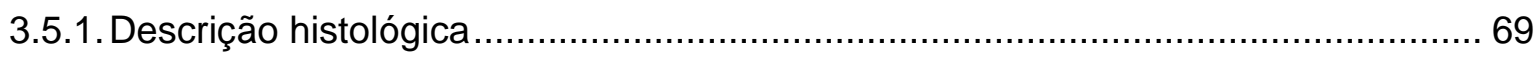

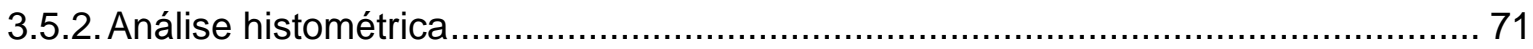

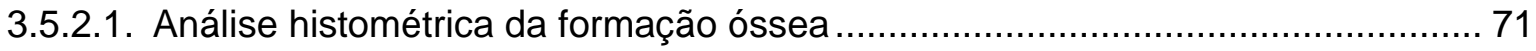

3.6. Precisão da Metodologia (Calibração do examinador) …..................................... 73

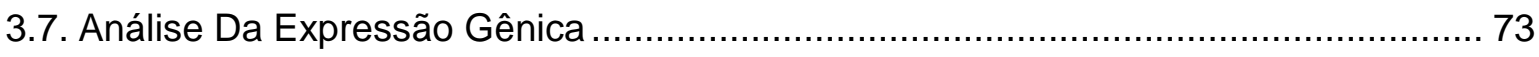

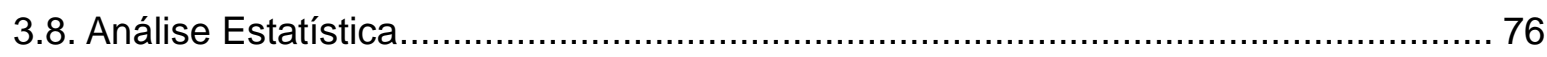

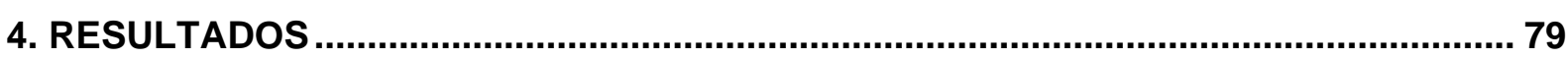

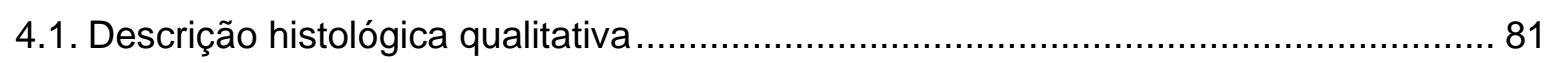

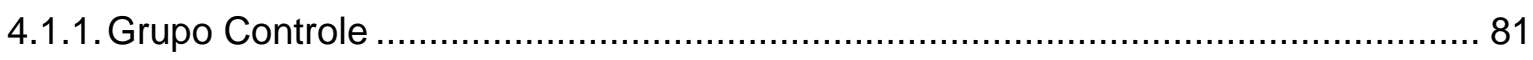

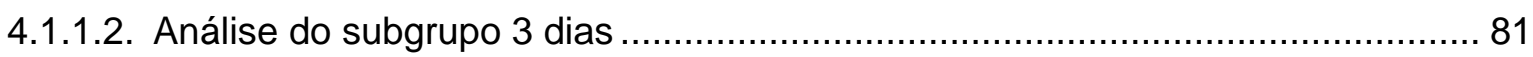

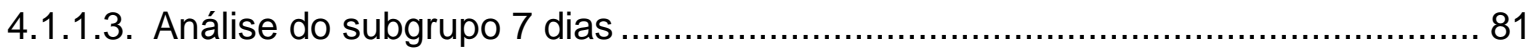

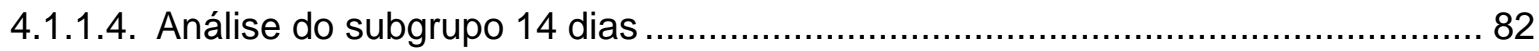

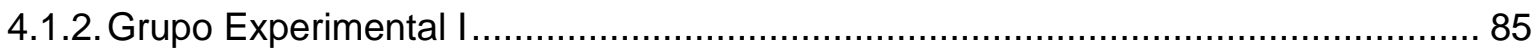

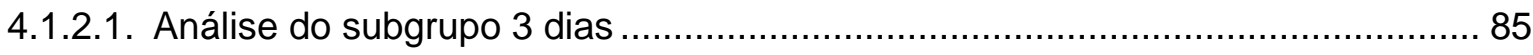

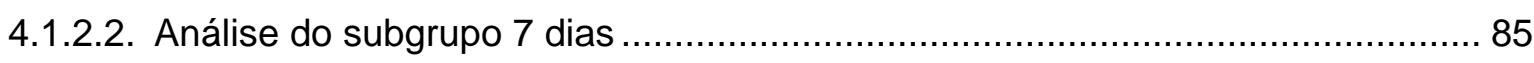

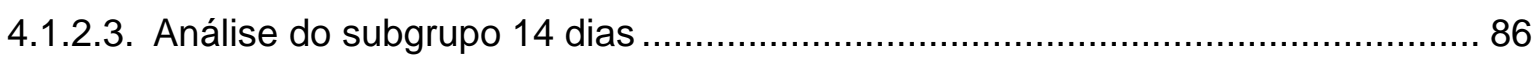

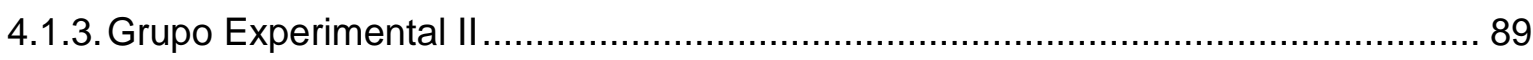

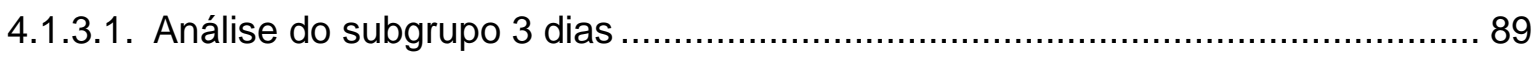

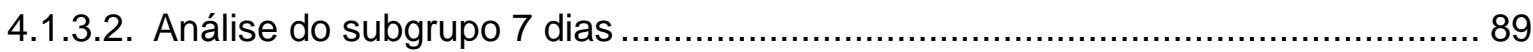

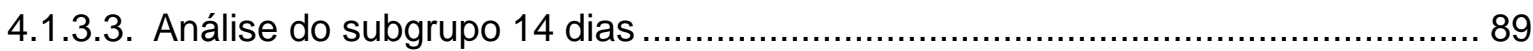




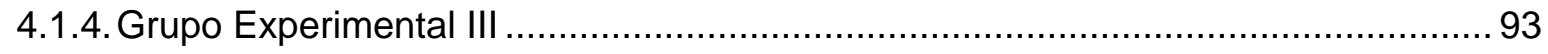

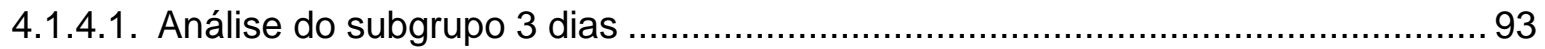

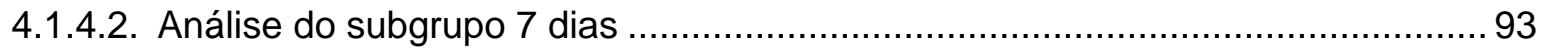

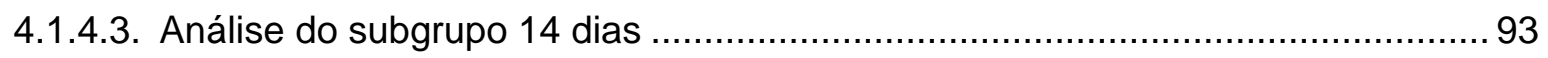

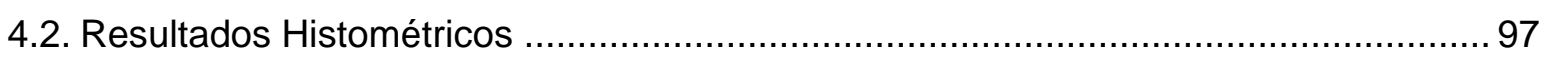

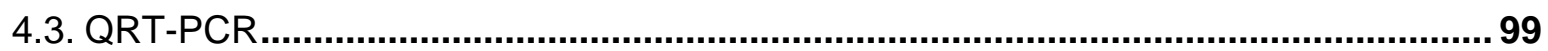

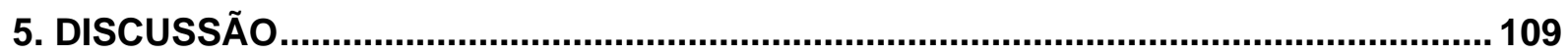

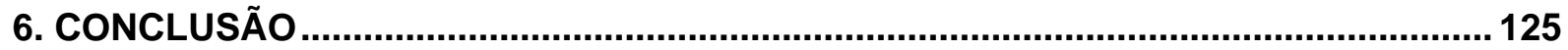

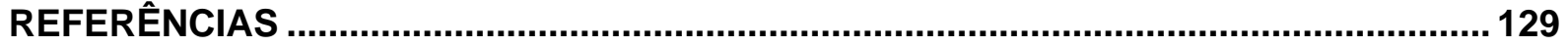

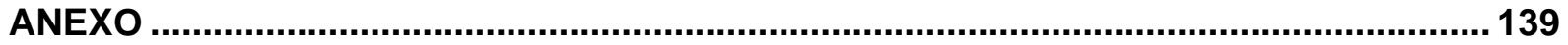


1. Introdução 



\section{INTRODUÇÃO}

O processo de reparo alveolar após extração dentária tem sido analisado pelos pesquisadores desde 1923 (Euler, 1923), e pode ser conceituado como o conjunto de eventos biológicos que ocorrem no interior do alvéolo dentário a partir da exodontia, e tem como objetivo fundamental preencher completamente o alvéolo dental com tecido ósseo (Kawasaki e Shimizu, 2000).

Após a exodontia, a cavidade da extração é preenchida por sangue e o coágulo que se forma a seguir, é gradativamente reabsorvido, à medida que é invadido por células endoteliais e fibroblastos que, originados de restos do ligamento periodontal, proliferam e migram para o seu interior. Forma-se então um tecido conjuntivo de reparo jovem, ricamente vascularizado e infiltrado por células inflamatórias linfoplasmocitárias (tecido de granulação). Na medida em que o tecido conjuntivo se torna progressivamente mais maduro pelo aumento da síntese de colágeno, diminui a quantidade de células inflamatórias e de vasos sanguíneos e começam a aparecer os osteoblastos na borda do alvéolo (Brugnera e Zanin, 1998; Calixto, 2001).

A regeneração óssea local é ativada por qualquer lesão óssea (fratura, defeito, fixação de implantes, extração dentária), através da liberação de fatores de crescimento $(F C)$ e indutores. Sendo o osso uma das fontes mais ricas em fatores de crescimento. A formação óssea inicia-se dois dias após a lesão, sendo totalmente preenchido por osso compacto após 28 dias em ratos (Okamoto e Fialho, 1990; Nicolau, 2001) e 64 dias em humanos (Amler, 1969).

O mecanismo de reparação óssea ocorre, em condições normais, inicialmente por um aumento da atividade osteoblástica, formando rapidamente tecido ósseo imaturo, matriz orgânica, seguida pelo depósito de sais de cálcio (Nicolau, 2001). Avaliando esse mecanismo, diversos estudos têm observado que o consumo de cigarros pode exercer um efeito importante sobre o metabolismo do tecido ósseo. E na odontologia, o tabagismo tem sido relacionado ao inadequado 
preenchimento sanguíneo dos alvéolos dentários pós-extração (Meechan et al., 1988), devido a vasoconstrição o que acarreta uma redução na microcirculação para os tecidos (Ozkan et al., 2014). Além disso, a nicotina reduz a produção de prostaglandina (Nadler et al., 1983; Nolan et al., 1985) e inibe a proliferação de fibroblastos (Silverstein, 1992).

Tendo em vista que o tabagismo é considerado uma doença pediátrica pela Organização Mundial da Saúde (OMS) onde 90\% dos fumantes começam a fumar até os 19 anos, e estima-se que entre 82 mil a 99 mil jovens começam a fumar a cada dia no mundo. A experimentação de cigarros vem aumentando entre escolares brasileiros, com maiores índices entre as meninas adolescentes. Os efeitos nocivos desse hábito não se limitam apenas ao organismo do indivíduo fumante. $O$ tabagismo passivo caracteriza-se pelo ato de inalar a fumaça de derivados do tabaco (cigarro, charuto, cigarrilhas, cachimbo e outros produtores de fumaça) proveniente de um fumante, fazendo com que os malefícios do fumo ocorram mesmo em não-fumantes. $\mathrm{O}$ ar poluído contém, em média, três vezes mais nicotina, três vezes mais monóxido de carbono, e até cinquenta vezes mais substâncias cancerígenas do que a fumaça que entra pela boca do fumante depois de passar pelo filtro do cigarro (Ministério da Saúde, 2002).

O hábito de fumar cigarros deve ser considerado com certa importância pelo profissional Odontopediatra uma vez que não só o fumante sofre com os efeitos prejudiciais característicos deste hábito. Em estudo recente, apoiado pela Organização Mundial da Saúde (OMS), estima-se que morrem todos os anos no mundo mais de 600000 não fumantes devido à exposição passiva ao fumo e que $28 \%$ destas mortes são crianças (Öberg et al., 2011). A OMS afirma ainda que aproximadamente dois bilhões de pessoas são vítimas do fumo passivo no mundo, sendo que destas, 700 milhões são crianças. No Brasil, as crianças são $40 \%$ das vítimas do fumo passivo.

A nicotina, devido aos seus efeitos tóxicos, provoca alterações graves no metabolismo ósseo, como por exemplo, um desequilíbrio na proliferação, diferenciação e na expressão celular (Rothem et al., 2011), inibição da síntese de fatores de crescimento angiogênicos específicos (Theiss et al., 2000), além de uma redução na concentração de fosfatase alcalina e na produção de colágeno tipo I por osteoblastos (Tanaka et al., 2005). 
Alguns dos efeitos da nicotina podem prejudicar o processo de reparo, como a liberação de catecolaminas que diminuem a perfusão tecidual e a alteração no metabolismo dos fibroblastos (Tipton e Dabbous, 1995), além da diminuição da proliferação de hemácias, macrófagos e fibroblastos (Sherwin e Gastwirth, 1990). Outros componentes da fumaça são ainda relacionados com alteração no processo de reparo, como o monóxido de carbono, que diminui a oxigenação dos tecidos (Sherwin e Gastwirth, 1990) e o cianeto de hidrogênio que inibe o metabolismo oxidativo e o transporte de oxigênio em nível celular (Mosely e Finseth, 1977).

A análise da chamada qualidade óssea, sob o ponto de vista molecular, tem grande potencial para contribuir para um melhor entendimento dessa característica de formação óssea em fumantes e/ou fumantes passivos submetidos à extração dentária. A identificação molecular de reguladores da reabsorção e formação óssea pode contribuir para a investigação da fisiopatologia óssea no alvéolo dentário e pode, em associação às análises histológicas, caracterizar melhor a qualidade óssea.

Neste contexto, uma das principais vias de diferenciação e ativação dos osteoclastos envolve o sistema RANK (receptor ativador do fator nuclear kappa B) RANKL (RANK ligante) - OPG (osteoprotegerina). O RANKL é uma molécula importante para a diferenciação das células hematopoiéticas progenitoras em osteoclastos maduros e exerce seus efeitos por meio de sua ligação ao receptor RANK (Nakagawa et al., 1998). Por outro lado, a osteoclastogênese é bloqueada na presença da OPG (Boyle et al., 2003), uma vez que quando OPG está ligada ao RANKL, este não pode ligar-se ao RANK, impossibilitando dessa forma que as células osteoprogenitoras se diferenciem em osteoclastos e assim não haja reabsorção óssea.

Diversos efeitos bioestimulatórios da radiação laser de baixa potência (LBP) têm sido avaliados envolvendo o reparo ósseo, em particular, a aceleração da regeneração óssea (Kawasaki e Shimizu, 2000; Prado et al., 2000; Pinfildi et al., 2009). Esses efeitos se processam de várias formas como, induzindo a atividade mitótica das células epiteliais (Kana et al., 1981), modificando a densidade capilar (Mester et al.,1978), estimulando a microcirculação local (Colls, 1984; Garcia, 1992) e, principalmente, aumentando a síntese do colágeno, tanto "in vitro" (Chomette et al., 1987a), quanto "in vivo" (Chomette et al., 1987b). Desde então, vários estudos (Kana et al., 1981; Takeda, 1988; Saito e Shimizu, 1997; Kawasaki e Shimizu, 2000; 
Freitas et al., 2001; Ueda e Shimizu, 2003) têm avaliado o seu emprego em diferentes tratamentos do complexo maxilo-facial. Avaliando esse mecanismo diversas pesquisas têm observado que 0 uso de laser de baixa potência pode exercer efeitos anti-inflamatórios e analgésicos além de modular a reparação tecidual, acelerando a cicatrização (Mester et al., 1978; Trelles e Mayayo, 1987; Pinheiro, 1998; Torricelli et al., 2001; Khadra, Kasem, Haanaes, Ellingsen e Lyngstadaas, 2004; Khadra, Ronold, Lyngstadaas, Ellingsen e Haanaes, 2004; Liu et al., 2007).

Desta forma, a investigação da relação entre a expressão de marcadores da reabsorção e da formação óssea pode contribuir para o entendimento da fisiologia dos diferentes tipos ósseos e abrir novos caminhos na definição da "qualidade óssea", conferindo bases para que outros estudos permitam conhecer o real impacto dessa característica óssea no resultado das exodontias.

A realização de exodontia em pacientes fumantes ou submetidos à inalação de fumaça de cigarro tem sido pouco estudada na literatura. O conhecimento dos diversos fatores que interferem no processo de formação óssea neste tipo de paciente ainda representa um desafio na área de Odontopediatria.

Pela constante necessidade da realização de exodontias, devido à doença cárie, por tratamento ortodôntico, ou mesmo pela exfoliação fisiológica dos dentes decíduos, em pacientes fumantes ou submetidos à inalação de fumaça de cigarro, optamos por realizar este estudo, utilizando o laser de baixa potência na tentativa de reduzir os efeitos deletérios da nicotina sobre a reparação óssea alveolar e para proporcionar uma aceleração da cicatrização e uma melhora no processo de remodelamento ósseo. Além das exodontias, pacientes fumantes ou fumantes passivos, com fraturas ósseas, necessidade de cirurgias ortognáticas ou movimentação ortodôntica também seriam beneficiados com os efeitos positivos do laser de baixa potência.

No mais não existem estudos na literatura avaliando a remodelação óssea em ratos submetidos à fumaça de cigarro e com aplicação de laser de baixa potência. Portanto, o objetivo deste estudo será compreender a biodinâmica da remodelação óssea após extração dentária em ratos submetidos ao laser de baixa potência na presença ou ausência da fumaça de cigarro. 
2. Proposição 



\section{PROPOSIÇÃO}

\subsection{Objetivo geral}

O objetivo do presente estudo foi avaliar in vivo a influência da aplicação do laser de baixa potência e da fumaça de cigarro sobre o processo de remodelação óssea após a extração dentária, por meio de análise miscroscópica e da expressão de genes envolvidos nesse processo.

\subsection{Objetivos específicos}

1. Avaliar a influência do laser de baixa potência na remodelação óssea, através da quantificação histológica do grau de formação óssea e da expressão de alguns genes relacionados à remodelação de osso.

2. Avaliar a influência da fumaça de cigarro na remodelação óssea, através da quantificação histológica do grau de formação óssea e da expressão de alguns genes relacionados à remodelação de osso.

3. Verificar se há diferença quantitativa do grau de formação óssea e da expressão gênica, entre os grupos experimentais, comparados com o grupo controle em diferentes tempos de remodelação óssea. 

3. Materiale Xétodos 



\section{MATERIAL E MÉTODOS}

\subsection{Amostragem}

Os procedimentos desta pesquisa obedeceram às recomendações éticas e legais especificadas para experimentação animal do Manual aprovado pelo Colégio Brasileiro de Experimentação Animal- COBEA 1991 e às recomendações legais conforme Lei № 6.638, de 08/05/1979, publicada no Diário Oficial da União, sendo aprovado pela Comissão de Ética no Uso de Animais (CEUA) da Universidade de São Paulo- Faculdade de Odontologia do Campus de Ribeirão Preto (FORP-USP), sob o protocolo no 2014.1.173.58.0.

A presente pesquisa utilizou 144 ratos da linhagem Wistar (Rattusnorvegicus, albinus) machos com 90 dias de vida (jovens em desenvolvimento) pesando em média $150 \mathrm{~g}$. Para determinar o $\mathrm{n}$ da amostra, o poder do teste foi de $80 \%$, com nível de significância de $5 \%$, determinando um número amostral de 12 animais por grupo. Os ratos foram fornecidos pelo Biotério Central da Universidade de São Paulo - campus Ribeirão Preto e transferidos para o Biotério da Faculdade de Odontologia de Ribeirão Preto da Universidade de São Paulo (FORP-USP), onde foram mantidos por 7 dias para adaptação. Animais machos foram utilizados para eliminar qualquer variabilidade hormonal devido ao ciclo reprodutivo feminino.

Durante todo o período experimental os animais foram alimentados com dieta padrão, constituída por ração moída (Labina - Purina) e água ad libitum. E permaneceram em gaiolas plásticas específicas para esse fim, com dimensões de $41 \times 34 \times 16 \mathrm{~cm}$ e com locais apropriados para a colocação de água e alimento, forradas com raspas de madeira (maravalha de pinus), ou seja, material totalmente inofensivo, atóxico, livre de peças pontiagudas, absorvente, isolante térmico, sem pó e não comestível pelos animais. Cada gaiola tinha um número máximo de três animais. $\mathrm{O}$ foto período foi controlado com intervalos de dia-noite de 12 horas, para evitar alterações no ciclo metabólico e a temperatura da sala do biotério estava entre 
$21^{\circ} \mathrm{C}$ e $23^{\circ} \mathrm{C}$, ideal para o crescimento e desenvolvimento dos animais. $\mathrm{O}$ local foi mantido constantemente arejado e limpo.

\subsection{Delineamento Experimental}

Para cada período experimental após a extração dentária $\left(3^{\circ}, 7^{\circ}\right.$ e $14^{\circ}$ dias $)$ foram utilizados doze animais $(n=12)$, distribuídos aleatoriamente de acordo com a Tabela 1.

Tabela 1: Grupos experimentais, tempos, número de animais e procedimentos propostos.

\begin{tabular}{|c|c|c|c|c|c|c|c|}
\hline \multirow{3}{*}{ GRUPOS } & \multicolumn{7}{|c|}{ № DE ANIMAIS (unidades) } \\
\hline & \multicolumn{2}{|c|}{3 dias } & \multicolumn{2}{|r|}{7 dias } & \multicolumn{2}{|c|}{14 dias } & \multirow{2}{*}{$\begin{array}{c}\text { DESCRIÇÃO DOS GRUPOS } \\
\text { EXPERIMENTAIS }\end{array}$} \\
\hline & PCR & Histológico & PCR & Histológico & PCR & Histológico & \\
\hline $\begin{array}{c}\text { Grupo } \\
\text { Controle } \\
\text { (Extração) }\end{array}$ & 6 & 6 & 6 & 6 & 6 & 6 & $\begin{array}{l}\text { Extração do primeiro molar } \\
\text { superior direito }\end{array}$ \\
\hline $\begin{array}{l}\text { Grupo } \\
\text { Experim. I }\end{array}$ & 6 & 6 & 6 & 6 & 6 & 6 & $\begin{array}{l}\text { Extração do primeiro molar } \\
\text { superior direito e aplicação } \\
\text { local de laser de baixa } \\
\text { potência }\end{array}$ \\
\hline $\begin{array}{l}\text { Grupo } \\
\text { Experim. II }\end{array}$ & 6 & 6 & 6 & 6 & 6 & 6 & $\begin{array}{l}\text { Extração do primeiro molar } \\
\text { superior direito com fumaça } \\
\text { de cigarro }\end{array}$ \\
\hline $\begin{array}{c}\text { Grupo } \\
\text { Experim. III }\end{array}$ & 6 & 6 & 6 & 6 & 6 & 6 & $\begin{array}{l}\text { Extração do primeiro molar } \\
\text { superior direito com fumaça } \\
\text { de cigarro e aplicação local de } \\
\text { laser de baixa potência. }\end{array}$ \\
\hline TOTAL & & & & 4 animais & & & $\begin{array}{c}\text { Total de animais } \\
\text { distribuídos nos diferentes } \\
\text { grupos experimentais }\end{array}$ \\
\hline
\end{tabular}

\subsection{Manipulação da amostra}

\subsubsection{Anestesia dos animais}

Todos os procedimentos nos animais foram realizados sob anestesia e sedação utilizando solução de Cloridrato de Ketamina (anestésico Ketamina Agener ${ }^{\circledR}$ ) associado com a solução de Cloridrato de Xilazina (Dopaser ${ }^{\circledR}$ ) $(60 \mathrm{mg} / \mathrm{kg}+10 \mathrm{mg} / \mathrm{kg})$ por via intramuscular.

\subsubsection{Exodontia do Primeiro Molar Superior Direito}

Depois de sedados e anestesiados, os animais foram colocados em uma mesa operatória apropriada em decúbito dorsal e com o auxilio de 2 abridores de boca confeccionados manualmente, foi possível visualizar melhor o campo operatório. Para a realização da exodontia do primeiro molar superior direito, foi utilizado o extrator de tártaro $n^{\circ} 1$ (Duflex). Para tal procedimento, a ponta ativa 
desse instrumento foi inserida na região cervical do primeiro molar entre as raízes, e com movimento de luxação e extrusão o dente foi extraído (Figura 1). Após a extração dentária foi feita irrigação com soro fisiológico e hemostasia com auxílio de pelotas de algodão estéril (Cremer). Todos os procedimentos operatórios foram realizados na sala de Cirurgia Experimental do Biotério da FORP-USP sempre com os mesmos operadores.

Figura 1: (A) Figura mostrando o procedimento de extração do primeiro molar superior direito e (B) alvéolo após a extração dentária.

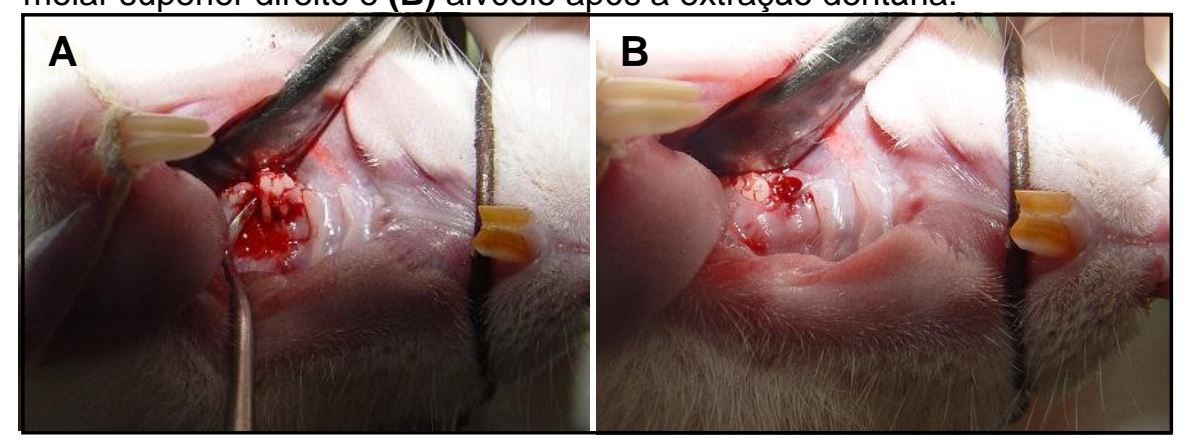

\subsubsection{Aplicação do Laser de Baixa Potência}

Nos animais dos Grupos Experimentais I e III logo após a exodontia, o alvéolo recebeu aplicação direta de radiação do laser de baixa potência semicondutor de Arseneto de Gálio e Alumínio (GaAIAs) (Photon Laser DMC® - São Carlos - SP), as aplicações foram realizadas durante três dias consecutivos, sendo a $1^{\circ}$ aplicação realizada imediatamente após a exodontia. Os parâmetros utilizados estão descritos na tabela 2.

Tabela 2: Grupos experimentais, tempos, número de animais e procedimentos propostos.

\begin{tabular}{ll}
\hline \multicolumn{1}{c}{ Parâmetros de irradiação } & \multicolumn{1}{c}{ Valores } \\
\hline Meio ativo & Diodo de Arseneto de Gálio e Alumínio (AsGaAl) \\
Densidade de energia (Fluência) & $54 \mathrm{~J} / \mathrm{cm}^{2}$ \\
Energia total & $162 \mathrm{~J} / \mathrm{cm}^{2}$ \\
Potência & $30 \mathrm{~mW}(0,003 \mathrm{~W})$ \\
Comprimento de onda & $830 \eta \mathrm{m}$ (infra-vermelho) \\
Cor & Invisível \\
Modo de emissãoo & Contínuo \\
Área de abrangência (área do spot) & $0,00785 \mathrm{~mm}^{2}$ \\
Distância da mucosa & Em contato/método pontual \\
Tempo de exposiçãoo pontual & $42 \mathrm{~s} /$ ponto único de aplicação \\
Número de aplicações & Aplicaçãoo única por 3 dias consecutivos \\
Diâmetro do feixe da ponteira & $6 \mathrm{~mm}$ \\
\hline
\end{tabular}


No caso do feixe de laser, a grandeza é a energia luminosa (medida em Joules) e a área é aquela abrangida pelo ângulo sólido formado pelo feixe sobre a superfície de aplicação (medida $\mathrm{em}^{\mathrm{cm}}{ }^{2}$ ), que nesse aparelho de aplicação pontual, é fixa $\left(0,00785 \mathrm{~mm}^{2}\right)$. Essa dosagem $\left(\mathrm{J} / \mathrm{cm}^{2}\right)$ foi aplicada calculando-se o tempo (s) necessário numa determinada potência $(\mathrm{mW})$ de $30 \mathrm{~mW}(0,003 \mathrm{~W})$, onde: $\mathrm{D}=\mathrm{PxT} / \mathrm{A}$. A ponta do laser é composta por uma fibra óptica $6 \mathrm{~mm}$ de diâmetro cuja área de irradiação corresponde a $0,00785 \mathrm{~mm}^{2}$, e a irradiação foi aplicada sob anestesia, colocando a extremidade da ponta da fibra óptica em contato com a mucosa palatal no local da extração dentária.

\subsubsection{Exposição à Fumaça de Cigarro}

A metodologia utilizada para a exposição dos animais à fumaça foi descrita inicialmente por Le Mesurier e colaboradores (1981) e readaptada por Nociti e colaboradores (2002). Trata-se de um recipiente de acrílico transparente, com dimensões de $45 \times 25 \times 20 \mathrm{~cm}^{3}$, composto por 2 câmaras interligadas por um orifício. Na primeira ficam armazenados os cigarros acesos. Nessa parte há também uma entrada por onde é bombeado ar, formando uma corrente que leva a fumaça para a segunda câmara, onde ficam os animais. Na segunda câmara há outro orifício que dá vazão ao ar bombeado (Figuras 2 e 3). A fumaça de cigarro oriunda do orifício da segunda câmara é direcionada para o ambiente externo através de uma mangueira conectada ao exaustor.

Figura 2: Desenho esquemático representando o mecanismo de exposição à fumaça. Observa-se a câmara 1 onde os cigarros foram posicionados e a câmara 2, onde os animais permaneceram durante a exposição à fumaça de cigarro.

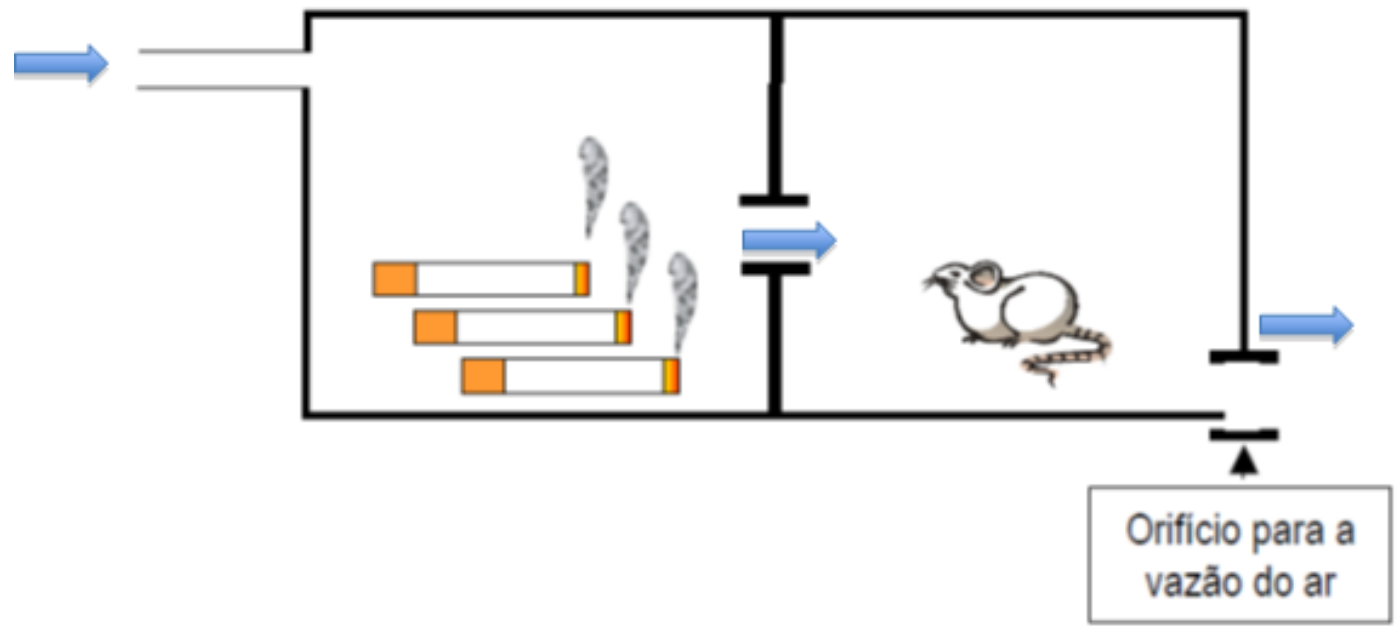


Figura 3: Câmara de exposição à fumaça de cigarro.

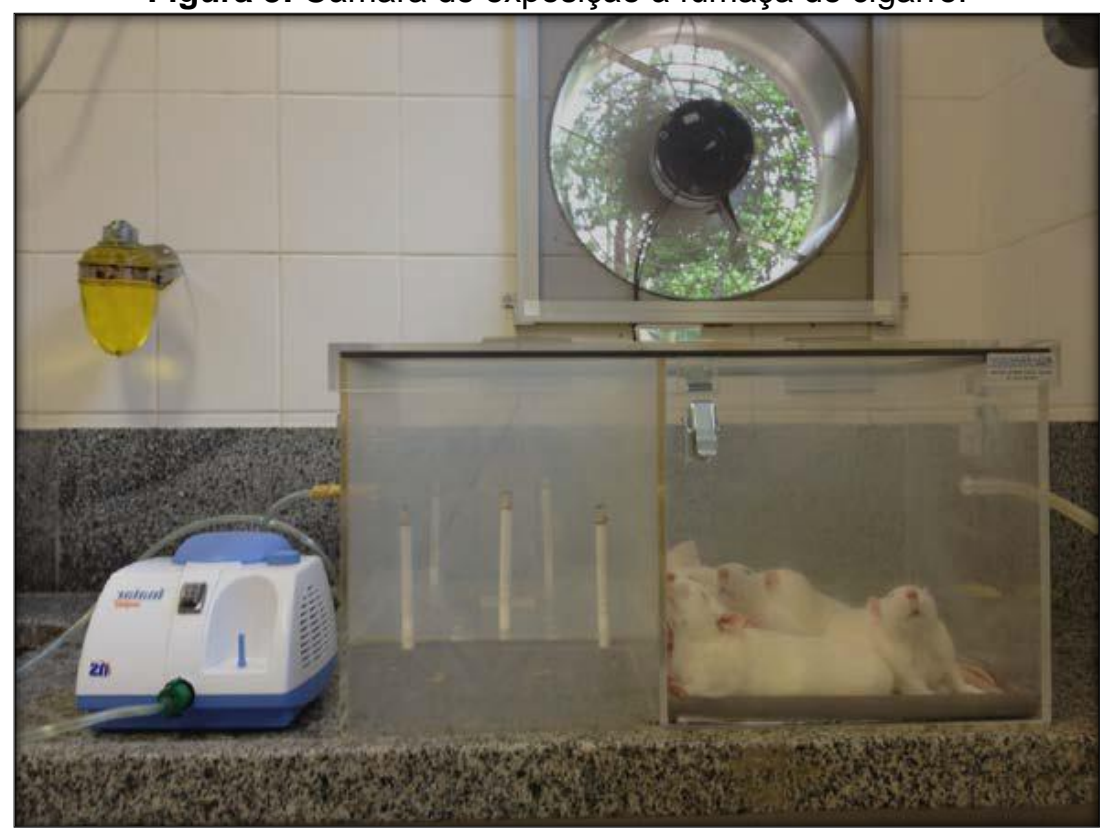

Os animais dos Grupos Experimentais II e III foram expostos à fumaça de 5 cigarros por dois períodos diários de 3 minutos cada, por um período de 21 dias antes de serem submetidos à extração dentária. Após a realização da exodontia, os animais continuaram a serem expostos à ação da fumaça de cigarro, de acordo como intervalo de dias preconizado para cada grupo experimental.

\subsubsection{Eutanásia dos animais e coleta dos Espécimes}

Os procedimentos operatórios foram realizados na sala de cirurgia experimental do Biotério I da FORP-USP, sob condições de limpeza, anti-sepsia e desinfecção, com instrumentos esterilizados em autoclave. Ao término dos períodos experimentais, os animais sofreram eutanásia por uma injeção de anestésico com Ketamina $(80 \mathrm{mg} / \mathrm{Kg})$ e Xilazina $(10 \mathrm{mg} / \mathrm{Kg})$, via intramuscular e, em seguida, os animais dos grupos destinados à avaliação por PCR foram decapitados e os animais dos grupos destinados à avaliação por análise histológica foram perfundidos por via intracardíaca utilizando bomba perfusora Masterflex LS (Cole-Parmer Instrumet Company, Vermon Hills, IL, USA). A perfusão foi realizada com 200ml de tampão fosfato salino a 10\%, pH 7,4 (PBS) a 38ㄷ $\mathrm{C}$ seguida de solução fixadora $(400 \mathrm{ml}) \mathrm{de}$ paraformaldeído (Sigma ChemicalCo., St. Louis, MO, USA) a 4\% em tampão fosfato de sódio (Sigma ChemicalCo.,St. Louis, MO, USA) a 0,1 M, pH 7,4 a 4ํㅡ. As maxilas foram então removidas e a hemi-maxila direita contendo o alvéolo em reparação foi 
separada da esquerda ao longo do plano sagital. Os espécimes dos grupos que foram analisados por PCR foram armazenados em tubos plásticos livres de RNAses (Eppendorf, São Paulo, Brasil), identificados e conservados em freezer a $-80^{\circ} \mathrm{C}$ para análise da expressão gênica. Os espécimes destinados para a análise histológica foram conservados em formol tamponado a $10 \%$ por 48 horas e posteriormente foi iniciado o processamento histológico.

\subsection{Preparo das peças para exame histológico}

Após a eutanásia, as peças foram fixadas em formol tamponado a $10 \%$ por 48 horas, em frascos individuais. Na sequência, os espécimes foram lavados em água corrente por 24 horas e colocados em solução desmineralizadora à base de EDTA a $10 \%$ (etileno-diaminotetra-acético), tamponado em pH neutro $(7,0-7,4)$, por um período de 4 semanas. Durante a descalcificação, as peças foram armazenadas individualmente, em frascos esterilizados, contendo quantidade de solução descalcificadora equivalente a vinte vezes o volume da peça. Esta solução foi renovada a cada 72 horas, com o intuito de preservar a matriz orgânica durante 0 processo de descalcificação. A confirmação da descalcificação das secções anatômicas foi realizada através de radiografias obtidas das peças anatômicas, durante o período de descalcificação, a fim de avaliar o grau de calcificação das peças.

Depois de submetidos à desmineralização, todos os espécimes foram imersos em sulfato de sódio a $5 \%$ por 24 horas à temperatura ambiente, com a finalidade de neutralizar a ação da solução descalcificadora. Os espécimes foram lavados em água corrente por 24h. Posteriormente, foi realizada desidratação em concentrações crescentes de álcoois, 70\%, 80\%, 90\% e 100\% (Reagen, PR, Brasil), sucessivamente, por 60 minutos à temperatura ambiente, a fim de evitar trocas osmóticas bruscas, o que poderia causar alterações nas estruturas teciduais. Concluída a desidratação, as peças foram diafanizadas em três banhos de xilol (Merck, RJ, Brasil). O xilol é miscível em álcool e em a parafina, isto é, remove todo o álcool das peças anatômicas e fornece ao tecido condições de ser impregnado pela parafina. O tempo de imersão em cada solução de xilol I, II e III dependeu da evolução da diafanização. De modo geral, as peças ficaram em torno de 60 minutos em cada solução. 
Após o xilol substituir todo o álcool nas peças, estas foram submetidas à parafinização lenta, promovida por seguidos banhos de xilol-parafina, nas proporções de 2:1, 2:2, e parafina pura (Reagen, PR, Brasil), sendo que as peças ficaram imersas uma hora em cada banho. Durante este procedimento as peças foram mantidas em estufa de temperatura constante regulada para $58^{\circ} \mathrm{C}$, até que o xilol fosse completamente substituído pela parafina fundida. Tão logo a infiltração se completou, as peças foram posicionadas no centro de formas de alumínio com dimensões aproximadas de 30 $\mathrm{mm}$ de extensão por $15 \mathrm{~mm}$ de largura e profundidade a qual foi preenchida com parafina fundida de baixa temperatura de fusão $\left(56-58^{\circ} \mathrm{C}\right.$, Reagen). Antes da solidificação, cada peça foi posicionada no centro da forma de alumínio com parafina, com o auxílio de uma pinça clínica (Duflex) aquecida, de tal modo que a superfície oclusal dos molares ficasse paralela ao sentido dos cortes desejados. Os blocos de parafina solidificados foram identificados e colocados em água gelada e, em seguida, no refrigerador, para evitar sua cristalização. Em seguida esses blocos foram removidos das formas de alumínio, reduzidos com navalhas apropriada, até permanecer $5 \mathrm{~mm}$ de parafina de cada lado da peça de interesse e alcançar paralelismo ideal para serem seccionados no micrótomo rotativo de precisão (Spencer, modelo 820).

Secções transversais semi-seriadas foram obtidas em micrótomo com $5 \mu \mathrm{m}$ de espessura. As fitas foram levadas ao cristalizador (Robertshaw, IL, EUA), onde foram distendidas e montadas em lâminas silanizadas para microscopia (Objektträger - Knittel Gläser, Bielefeld, Alemanha). Posteriormente, estas lâminas foram mantidas em estufa, em posição vertical, por 24 horas, a $40^{\circ} \mathrm{C}$, para favorecer a remoção da umidade e aderência do material à lâmina.

As lâminas foram divididas em dois grupos, sendo que o primeiro grupo foi corado pela técnica de Hematoxilina e Eosina $(H / E)$, para a análise morfológica e o segundo grupo com Tricrômico de Masson (TM), a fim de evidenciar a neoformação óssea e o colágeno existente no tecido conjuntivo mineralizado e não mineralizado.

\subsubsection{Coloração dos cortes para microscópio de luz}

Para que o corte pudesse ser submetido à coloração, foi realizada a desparafinização das lâminas. Para isso procedeu-se primeiro à eliminação da parafina dos cortes pelo xilol, mergulhando as lâminas em soluções de xilol I, II e III, com duração de 10 minutos em cada solução. Assim que foi constatada a eliminação 
da parafina dos cortes, foi iniciado o processo de hidratação, quando o xilol foi removido com banhos de álcool absoluto I, II e III, (Reagen) e, em seguida álcool $95 \%$, por 3 minutos em cada solução, até chegar à água destilada. Esse procedimento tem a finalidade de evitar fenômenos osmóticos bruscos, os quais produzem retrações e deslocamento do material da lâmina. Os cortes histológicos foram montados em série e corados com hematoxilina e eosina $(\mathrm{H} / \mathrm{E})$ e tricrômico de Masson (TM).

Para a coloração por $\mathrm{H} / \mathrm{E}$, os cortes hidratados foram submetidos à coloração pôr hematoxilina (Merck) por 3 minutos. Em seguida, realizou-se a lavagem das lâminas em água corrente até assumirem tom azulado, sendo então, mergulhadas rapidamente em solução de álcool acetificado (solução de ácido acético glacial diluído em álcool 95\%). Nova lavagem foi realizada em água corrente por 2 a 5 minutos e álcool a 95\%. A eosina foi utilizada (Merck) pôr 2,5 minutos, dando aos tecidos uma cor rosada. A seguir foi realizada nova desidratação através de três banhos de álcool absoluto I, II e III por 3 minutos cada, e três banhos de xilol (Merk) I, II e III também por 3 minutos cada. Finalmente, as lâminas foram cobertas com lamínulas montadas com Entellan (Merck).

Para a coloração por TM, os cortes hidratados foram submetidos à coloração pôr Alumen de ferro a $5 \%$, dentro da estufa $\left(38^{\circ} \mathrm{C}\right.$ a $\left.40^{\circ} \mathrm{C}\right)$ por $17 \mathrm{~min}$. Em seguida, realizou-se a lavagem das lâminas em água corrente, seguida por água destilada. Os cortes foram então submetidos à coloração pôr Hematoxilina de Regaud dentro da estufa $\left(38^{\circ} \mathrm{C}\right.$ a $\left.40^{\circ} \mathrm{C}\right)$ por 15 minutos. Em seguida realizou-se a lavagem em água destilada sendo então, mergulhadas rapidamente em solução de álcool 95\%, e em seguida mergulhadas também rapidamente em solução de álcool pícrico por 30 segundos. As lâminas foram então, submetidas à nova lavagem em água deslitada $\mathrm{e}$ a Mistura de Ponceau por 12 minutos. Os cortes foram mergulhados rapidamente em água acetificada a 1\% (solução de ácido acético glacial diluído em água destilada) e submetidos à solução de Ácido fosfomolibídico a 1\% por 15 minutos. Nova lavagem em água destilada foi realizada e os cortes foram submetidos à solução de Azul de anilina por 3 minutos, seguida por lavagem rápida em água acetificada à $1 \%$, submetidas à solução de Ácido fosfomolibídico por 2 minutos e nova lavagem rápida em água acetificada a $1 \%$. A seguir foi realizada nova desidratação através de três banhos de álcool absoluto I, II e III por 3 minutos em 
cada e três banhos de xilol I, II e III também por 3 minutos cada. Finalmente, as lâminas foram cobertas com lamínulas montadas com Entellan (Merck).

Terminada a montagem e secagem das lâminas, estas com os respectivos cortes corados foram rotuladas, onde os cortes foram identificados, e, posteriormente, foram acondicionadas em caixas apropriadas e armazenadas em ambiente seco e fresco, estando, finalmente, prontos para exame histológico ao microscópio de luz.

\subsection{Análise dos resultados}

\subsubsection{Descrição histológica}

O alvéolo foi didaticamente dividido em terço cervical, médio e apical para realizar a análise histológica e histométrica. Os eventos histológicos descritos foram observados em toda a extensão do alvéolo, ou seja, nos três terços. Para análise microscópica descritiva, foram selecionadas aleatoriamente dez lâminas, contendo três cortes corados em cada uma, totalizando 30 cortes para cada tempo experimental. Os cortes corados pela técnica de H/E e TM foram analisados, por um único avaliador calibrado e cego ao tratamento realizado, através da microscopia de luz com a descrição das características do processo de reparo ósseo, revascularização e neoformação óssea na região da exodontia. Para análise das fibras colágenas foi utilizada a coloração de TM.

A leitura das estruturas histológicas foi realizada com 0 auxilio do microscópio óptico HM-LUX (Wild Leitz, Periplan), com as seguintes resoluções: 10 NF X 3.2, para visualização panorâmica do preparo histológico; 10 NF x 20, para identificação e visualização das estruturas do osso neoformado e $10 \mathrm{NF} X$ 40, para identificação das células e demais estruturas.

Após a análise, as imagens histológicas em H/E e TM foram capturadas para análise, com o auxílio do microscópio Olympus BX-BX61 (Olympus, Tokio, Japão) acoplado a uma câmera de captação de imagem (Olympus, Tokio, Japão) conectada a um microcomputador DELL ${ }^{\circledR}$ (Dell Inc., Round Rock, USA), com software DP2$\mathrm{BSW}^{\circledR}$ (Olympus) para captura e análise de imagens digitalizadas.

O objetivo da análise histológica foi investigar os eventos morfológicos que ocorreram no interior do alvéolo dental, focando na presença de remodelação óssea. A vitalidade do tecido conjuntivo e ósseo foi observada por meio da análise microscópica com auxílio do microscópio de transmissão de luz e considerou-se 
como critério de avaliação qualitativa a observação de tecido conjuntivo com presença de camada de osteoblastos delimitando as bordas ósseas, com vasos sanguíneos, fibroblastos e outros tipos celulares na porção central desse tecido, áreas de fibras colágenas, presença ou não de processo inflamatório, formação e organização do tecido conjuntivo, ósseo e medular, e remodelação óssea.

Para a histometria a região do terço médio dos alvéolos mésio-vestibular e mésio-palatino foi escolhida. $O$ terço médio foi utilizado para a análise, pois, o processo de reparo alveolar ocorre de maneira mais homogênea nesta região (Okamoto e de Russo, 1973; Carvalho e Okamoto, 1987), em virtude da interferência do ato cirúrgico no terço cervical e apical, respectivamente, pelo uso do instrumental para a exodontia e sonda exploradora na curetagem alveolar.

\subsubsection{Critérios Morfológicos}

Os critérios morfológicos adotados para identificação dos tipos celulares avaliados foram os seguintes:

- Osteoblastos: células ósseas dispostas na superfície óssea, lado a lado, num arranjo que lembra o epitélio simples. Em intensa atividade sintética mostram-se cubóides e com citoplasma muito basófilo e em estado pouco ativo. São achatados e apresentam fraca basofilia citoplasmática.

- Osteócitos: células ósseas presentes nas lacunas no interior da matriz óssea.

- Osteoclastos: células ósseas multinucleadas responsáveis pela reabsorção da matriz óssea mineralizada e desmineralizada.

- Fibroblastos: são as células mais comuns do tecido conjuntivo, apresentam intensa atividade de síntese, sua função é formar a substância fundamental amorfa e são capazes de modular sua capacidade metabólica.

- Linfócitos: é um tipo de leucócito (glóbulo branco) presente no sangue e tem um papel importante na defesa do corpo.

- Histiócitos: são macrófagos inativos, fixos, com os pseudópodes retraídos e com aspecto ovóide.

- Neutrófilos: são leucócitos polimorfonucleados e estão envolvidos na defesa do organismo.

- Macrófagos: células de grandes dimensões do tecido conjuntivo, ricos em lisossomas, que fagocitam elementos estranhos ao corpo e intervêm na defesa do organismo contra infecções. 


\subsubsection{Análise histométrica}

Para a realização da análise histomorfométrica, foi utilizado o método "estereológico" ou "casualização de amostra" que consiste em determinar parâmetros quantitativos tridimensionais de estruturas anatômicas a partir de cortes histológicos, com intuito de eliminar a ocorrência de vício na amostragem. O referido método baseia-se no princípio geométrico-estatístico, derivados da probabilidade das imagens e dos perfis da estrutura no corte histológico, resultando num sistemateste efetivo. Portanto, realizaram-se os procedimentos de escolhas aleatórias para as seguintes fases do experimento: seleção dos animais, dos blocos histológicos, das lâminas histológicas, dos cortes e campos histológicos.

Todas as medidas foram realizadas por um mesmo pesquisador que desconhecia os grupos experimentais e os tratamentos realizados. O pesquisador foi submetido a um rigoroso processo de calibração pela repetição de mensurações, em um intervalo de 48 horas, utilizando $10 \%$ do total das imagens digitais, selecionadas aleatoriamente. A calibração foi aceita se a concordância existente entre as medidas iniciais e aquelas realizadas após 48 horas era maior ou igual a $90 \%$.

\subsubsection{Análise histométrica da formação óssea}

Para os cortes corados por H/E e TM foi realizada uma análise quantitativa do tecido ósseo neoformado no alvéolo em $\mu \mathrm{m}^{2}$ com o auxílio do Software IMAGE J) seguindo a metodologia de César-Neto et al., 2006. Após exclusão, da primeira e da última secção na qual a região de furca foi evidente (terço médio do alvéolo), cinco secções equidistantes de cada animal foram selecionadas para análise histométrica. Por meio de uma objetiva de aumento de 40x Olympus (Olympus BX-BX61, Tokio, Japão) as imagens foram capturadas, salvas em formato de figura (.tif) e transferidas para o software IMAGE J. Sempre usando os recursos do software IMAGE J, procedeu-se ao cálculo da Área Total (AT) e da área de Osso Neoformado (AON), transferindo os valores medidos para uma "Planilha de Cálculos".

Critérios baseados no estudo de Messora et al., 2008 foram usados para padronizar a análise histomorfométrica das imagens digitais. Para a análise histométrica, foi realizada a individualização e delimitação da área do alvéolo dentário. Esta área foi denominada de Área Total (AT) sendo que esse valor foi considerado como $100 \%$ da área total do alvéolo analisada. A seguir o cálculo da área de Osso Neoformado (AON), anteriormente delimitada, também foi obtido. Para 
isto, dentro da Área Total (AT), realizou-se a delimitação das várias áreas correspondentes ao osso neoformado (Figura 4). Este tecido ósseo presente no campo foi delimitado manualmente e foi obtido o "Cálculo de regiões" através da soma dessas várias áreas de formação óssea.

Figura 4: Foto ilustrativa de um corte histológico onde é calculado a área do alvéolo (limite amarelo) e a área de osso neoformado (limites vermelhos) utilizando o ImageJ.

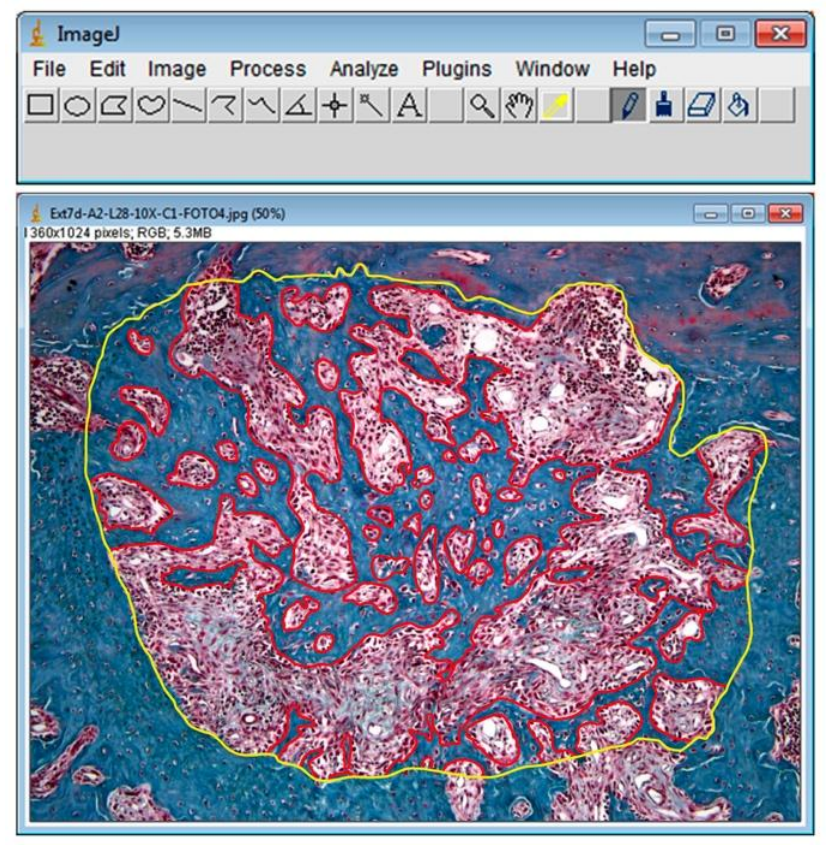

O valor de osso neoformado no interior de cada alvéolo (AON) foi calculado como uma percentagem de área total do alvéolo (AT), da seguinte forma:

Medida de AT $=100 \%$ da área analisada:

$$
\text { AON \% } \Rightarrow 100 \times \text { AON }
$$

Os seguintes critérios foram usados para padronizar a análise histométrica: 1) análise de apenas cinco lâminas (10 cortes histológicos) de cada animal; 2) delimitação de vinte campos (alvéolo mesio-vestibular e mésio-palatino) de tamanhos equivalentes no terço médio do alvéolo; 3) padronização no tamanho e posição dos campos; 4) a área total (AT) da interface foi delineada correspondendo à área total do defeito cirúrgico, que no caso corresponde ao espaço do alvéolo dentário após a exodontia, que foi delimitada manualmente contornando a parede 
interna do osso alveolar. A AT foi medida em $\mu^{2}{ }^{2}$ e considerada $100 \%$ da área a ser analisada; 5 ) as regiões correspondentes às áreas de osso neoformado (AON) foram delimitadas dentro da área total (AT) e esta área foi calculada pelo delineamento de cada unidade óssea separadamente em $\mu \mathrm{m}^{2}$, e então o somatório dessas unidades; 6) os valores de AON de cada animal foram usados para o cálculo das médias e dos desvios-padrões de cada grupo.

\subsection{Precisão da Metodologia (Calibração do examinador)}

Para a confiabilidade dos resultados desse trabalho, procurou-se minimizar os erros dos métodos de mensuração empregados. Calculou-se a precisão do investigador pelo erro sistemático intraexaminador. O erro sistemático reflete uma falta de padronização do método, uma vez que o examinador tende a sub ou superestimar os valores de suas medições de maneira inconsciente, de modo a direcionar os resultados de acordo com as expectativas em relação às conclusões do estudo. Para avaliar a calibração do examinador, nas mensurações de cada espécime, foi realizada, previamente às leituras finais, a correlação intraclasse. Vinte cortes foram aleatoriamente selecionados e suas contagens foram feitas e repetidas três semanas após a primeira medição pelo mesmo examinador. $O$ teste $t$ pareado foi usado para analisar o erro intraexaminador sistemático do método, por meio da comparação dos valores das duas análises distintas com intervalo de 30 dias. Valores de $p<0,05$ foram considerados para estimar a viabilidade de utilização do método proposto. Assim, observou-se que erros na verificação da precisão desse estudo foram admissíveis, promovendo resultados fidedignos.

\subsection{Análise da expressão gênica}

Os protocolos utilizados foram seguidos de acordo com Sambrook e Russel (2006) de uso comum na expressão gênica - Reação Quantitativa de Polimerase em Cadeia em Tempo Real (qRT-PCR), a fim de entender e explicar como o processo de remodelação óssea na região do alvéolo dentário estava sendo regulado geneticamente. Inicialmente os espécimes foram pesados para dar sequência às diversas etapas para posterior avaliação da expressão gênica. 


\section{a) Extração do RNA total}

As hemi-maxilas armazenadas em freezer a $-80^{\circ} \mathrm{C}$, para análise da expressão gênica, foram descongeladas à temperatura ambiente (25두), remanejadas com pinça universal no 317 para tubos de $2 \mathrm{ml}$ estéreis identificados por grupo e período experimental e pesadas. Para extração do RNA total do tecido ósseo do alvéolo dentário, foi adicionado $600 \mu \mathrm{l}$ de tampão de lise (Lysis Buffer, PureLink® RNA Mini Kit, Invitrogen, Estados Unidos), conforme protocolo do fabricante, seguida da trituração das amostras através de sonicador (Dispersor T10 Basic ULTRA-TURRAX®, IKA, Estados Unidos) em alta rotação, à temperatura ambiente $\left(25^{\circ} \mathrm{C}\right)$ e homogeneização em vortex. Em seguida, foi realizada a centrifugação a $12.000 \mathrm{G}$, por 5 minutos, a $4^{\circ} \mathrm{C}$. O sobrenadante foi coletado e transferido para um tubo novo, ao qual foi adicionado $300 \mu \mathrm{l}$ de álcool $70 \%$ e homogeneizado em vortex. A solução foi transferida para um tubo de coluna estéril contendo uma membrana central em sílica, este foi submetido á centrifugação novamente, a 12.000G, por 30 segundos, a $4^{\circ} \mathrm{C}$. O filtrado contendo proteínas foi coletado em um novo tubo estéril corretamente identificado, liofilizado e armazenado em freezer $-80^{\circ} \mathrm{C}$ para futuras análises.

À coluna, foi adicionado $700 \mu$ de tampão de lavagem I (Wash Buffer I, PureLink ${ }^{\circledR}$ RNA Mini Kit, Invitrogen, Estados Unidos), centrifugado a $12.000 \mathrm{G}$, por 30 segundos, à $4^{\circ} \mathrm{C}$, descartando-se o filtrado. Repetiu-se esta ultima etapa por 2 vezes, utilizando-se $500 \mu$ l de tampão de lavagem II (Wash Buffer II, PureLink ${ }^{\circledR}$ RNA Mini Kit, Invitrogen, Estados Unidos), descartando-se os filtrados.

A coluna contendo a membrana de sílica foi acoplada a um novo tubo coletor, submetido à centrifugação a $12.000 \mathrm{G}$, por 2 minutos, a $4^{\circ} \mathrm{C}$, para secagem da membrana de sílica. Foi adicionado $40 \mu \mathrm{l}$ de água livre de enzima RNA (RNase FreeWater, PureLink ${ }^{\circledR}$ RNA Mini Kit, Invitrogen, Estados Unidos) sobre a membrana de sílica, e então submetido à centrifugação a $12.000 \mathrm{G}$, por 2 minutos, a $4^{\circ} \mathrm{C}$, a coluna contendo a membrada foi entao descartada e o filtrado obtido no tubo coletor era o RNA total.

O RNA total foi avaliado quanto à concentração e a pureza do RNA, determinadas pela leitura da densidade óptica (absorbância) das soluções de RNA total em nanoespectrofotômetro (ND 100, Nanodrop Techonologies, Estados Unidos) nos comprimentos de onda de 230 a 280nm. A relação A230/A260nm foi considerada aceitável se estivesse acima de 2.0, e A260/A280 aceitável se estivesse 
entre 1.8 e 2.0, pois valores nesse intervalo indicam boa qualidade da amostra em relação à contaminação (Sambrook e Russel, 2006).

\section{b) Síntese do DNA complementar (cDNA)}

A síntese do cDNA foi obtida a partir do RNA total através da reação de transcrição reversa. As amostras armazenadas em freezer a $-80^{\circ} \mathrm{C}$ foram descongeladas e mantidas em gelo. Novos tubos eppendorfs de $0,1 \mathrm{ml}$ foram preparados com suas respectivas identificações para transcrição do cDNA.

O cDNA foi sintetizado utilizando-se $2 \mu$ de RNA total de cada amostra, por reação de transcrição reversa, utilizando o kit específico (High Capacity cDNA Reverse Transcription Kit, Applied BioSystems) de acordo com o protocolo descrito pelo fabricante. Adicionou-se às amostras a quantidade recomendada pelo fabricante de cada componente do kit para obtenção de um volume final de $20 \mu \mathrm{l}$, para a realização da reação de transcrição reversa.

A reação foi realizada em termociclador (Eppendorf Mastercycler Gradient, Eppendorf, Itália). As amostras foram colocadas em placas adaptadas para termociclador programado para atingir as condições de ciclagem recomendadas pelo fabricante, a 25ํ $\mathrm{C}$ por 10 minutos para ligação do primer ao RNA, seguida de incubação a $37^{\circ} \mathrm{C}$ por 120 minutos para transcrição reversa utilizando a enzima transcriptase reversa, e posterior incubação a $85^{\circ} \mathrm{C}$ por 5 minutos para inativação da enzima e finalização do processo.

Os cDNAs obtidos foram diluídos 10x em água livre de enzima RNA (RNase FreeWater, PureLink® RNA Mini Kit, Invitrogen, Estados Unidos), e posteriormente armazenados em freezer a $-20^{\circ} \mathrm{C}$ até a realização do qRT-PCR.

\section{c) PCR em tempo real (qRT-PCR)}

A reação da polimerase em cadeia tem por objetivo amplificar os cDNAs provenientes das diferentes amostras, obtendo amplicons (segmentos de DNAC gerado pelo processo de PCR) em escala exponencial.

Os cDNAs dos genes de interesse Tnfrsf11a (Rank), Tnfsf11 (Rankl), Tnfrsf11b (Opg), Bglap (Occ), Sparc (Onc), Bmp2 (Bmp-2), Ibsp (Bsp), Spp1 (Opn) e o gene de controle endógeno GAPDH (gliceraldeido-3-fosfato desidrogenase ) (Bustin, 2000), foram amplificados em aparelho para PCR em tempo real. As leituras de fluorescência foram realizadas pelo equipamento StepOne Plus (Applied 
Biosystems ${ }^{\circledR}$, Foster City, CA, EUA). As amplificações por PCR foram realizadas em duplicatas utilizando $2 \mu \mathrm{l}$ de cDNA por reação, e a água livre de enzime RNAase (RNase FreeWater, PureLink ${ }^{\circledR}$ RNA Mini Kit, Invitrogen, Estados Unidos) foi usada como controle negativo e o RNA de uma das amostras foi adicionado aos primers ao invés de cDNA, para confirmar ausência de DNA genômico para os experimentos da reação de qRT-PCR.

As reações foram preparadas com TaqMan ${ }^{\circledR}$ Universal PCR Master Mix (Applied Biosystem, Estados Unidos) adicionado aos primers contendo as sondas específicas para os genes alvos para obtenção de uma solução com volume final de $5 \mu \mathrm{l}$ por poço.

As condições de ciclagem térmica foram realizadas de acordo com as recomendações de tempo e temperatura propostas pelo fabricante (um ciclo inicial a $50^{\circ} \mathrm{C}$ por 2 minutos; ativação da enzima polimerase a $95^{\circ} \mathrm{C}$ por 20 segundos; e 40 repetições (ciclos de amplificação) para desnaturação a $95^{\circ} \mathrm{C}$ por 3 segundos e anelamento e extensão da fita de $\mathrm{CDNA}$ a $60^{\circ} \mathrm{C}$ por 30 segundos).

Os resultados foram analisados com base no valor do ciclo limiar (Ct, Cicle Threshold), sendo este o ponto correspondente ao número do ciclo obtido na fase de amplificação exponencial das amostras que permite a análise quantitativa da expressão do gene avaliado. Os resultados individuais expressos em valores de Ct foram a seguir transferidos para planilhas e agrupados de acordo com os diferentes grupos e tempos experimentais, para a realização da análise estatística.

O cálculo de expressão relativa dos genes foi normalizado pela expressão na condição controle, ou seja, pela diferença entre $\Delta \mathrm{Ct}$ das amostras (Ct do gene alvo - Ct do gene endógeno constitutivo) e a média obtida do $\Delta \mathrm{Ct}$ dos animais do grupo controle do periodo de 3 dias -calibrador-, resultando os valores de $\Delta \Delta \mathrm{Ct}$ de cada animal. Em seguida, foi realizado o cálculo da expressão de cada gene avaliado com base na equação (Livak e Schmittgen, 2001):

\section{Expressão relativa $=2^{-\Delta \Delta C t}$}

\subsection{Análise Estatística}

A hipótese de não haver diferença estatisticamente significante na taxa de formação óssea na região de alvéolos dentários em regeneração entre os diferentes períodos e tipo de tratamento (laser e fumaça de cigarro) entre os grupos foi testada. 
A análise estatística dos dados histométricos obtidos foi demonstrada através da significância das diferenças entre grupos em relação às porcentagens de tecido ósseo neoformado. A análise estatística foi realizado com o programa de estatística GraphPad Prism versão 5 (GraphPad Software Inc., San Diego, CA), tendo sido adotado o nível de significância de $5 \%(p<0,05)$ para que as diferenças fossem consideradas estatisticamente significativas, ou seja, para rejeitar a hipótese nula.

$\mathrm{Na}$ análise intra-grupo o teste paramétrico de análise de variância (OneWay ANOVA) foi utilizado e, quando detectada diferença estatisticamente significante foi utilizado o teste paramétrico de Tukey-Kramer, detectando assim a diferença significativa entre os grupos dentro do mesmo ensaio.

A análise intergrupo (efeito do tratamento) testou a hipótese de que a aplicação do laser de baixa potência e da fumaça de cigarro modifica a reparação óssea através da alteração dos parâmetros pesquisados, utilizando-se o teste paramétrico de análise de variância (Two-Way ANOVA). Quando detectada diferença estatisticamente significante o pos-teste Bonferroni foi utilizado.

Os resultados do qRT-PCR para cada gene foram agrupados de acordo com os diferentes grupos de estudo e de período experimental, e submetidos à analise de variância Anova (one-way e two-way) seguido pelo pós-teste de Tukey e Bonferroni. A diferença foi considerada estatisticamente significante quando $p<0.05$. 

4. Resultados 



\section{RESULTADOS}

A fim de permitir a comparação, as ocorrências verificadas nos grupos controle e experimentais foram apresentadas juntas seguindo-se os períodos cronológicos de sacrifício dos animais. Para facilitar a comparação dos resultados o alvéolo dental foi dividido em três terços: cervical, médio e apical, considerados a partir da margem gengival, em direção ao fundo do alvéolo. Os resultados obtidos foram descritos, após análise das seguintes estruturas: restos do ligamento periodontal, tecido conjuntivo, tecido ósseo néo-formado, cavidades medulares e parede alveolar.

\subsection{Descrição histológica qualitativa}

\subsubsection{Grupo Controle}

\subsubsection{Análise do subgrupo 3 dias}

O terço apical do alvéolo dental mostrou-se ainda preenchido por coágulo sanguíneo, exibindo numerosos macrófagos em seu interior, sendo que o processo inflamatório com células mononucleadasm estava evidente neste período. Junto à parede óssea nos terços médio, pôde-se observar o ligamento periodontal remanescente com moderado número de vasos sanguíneos e elevado número de fibroblastos. A grande proliferação de fibroblastos predominou neste período. Alguns delgados tabiques ósseos foram observados, principalmente o terço médio do alvéolo. A crista óssea alveolar em alguns casos apresentou discreta reabsorção com presença de osteoclastos, principalmente no interior das cavidades medulares (Figura 5).

\subsubsection{Análise do subgrupo 7 dias}

A análise das cavidades de extração dentária, no tempo pós-operatório de sete dias evidenciou presença de áreas ainda bem delimitadas, onde os limites de trabéculas ósseas periféricas exibiam acentuado número de células multinucleadas 
da linhagem osteoclásticas. O epitélio da mucosa gengival recobria totalmente 0 alvéolo dental, e o tecido conjuntivo subjacente mostrou-se bem desenvolvido. Em toda a extensão do alvéolo dental, observou-se tecido ósseo neoformado, porém com características distintas em cada terço. Assim, junto ao terço cervical, a ossificação foi bastante discreta, observando-se tecido ósseo pouco diferenciado caracterizado pela presença de trabéculas ósseas esparsas e imaturas, porém com intensa atividade osteoblástica em suas bordas sem, contudo definir espaços medulares em contiguidade ao tecido de granulação celularizado presente no centro do alvéolo. Foi evidenciada ainda, grande quantidade de tecido conjuntivo sem diferenciação óssea, refazendo a morfologia do alvéolo dental, muito embora esteja evidente uma redução da dimensão do alvéolo no sentido vestíbulo-lingual nesta porção alveolar. Ocasionalmente, notou-se pequena porção de coágulo sanguíneo remanescente sem organização nesta região. Os terços médio e apical encontramse preenchidos por trabéculas ósseas espessas e bem definidas com osteoblastos na periferia constituindo o início de deposição óssea no reparo tecidual, com reduzido espaço intertrabecular próximo às corticais, definindo alguns espaços medulares, enquanto que nas áreas centrais, o tecido ósseo trabecular encontra-se ainda delgado. $O$ espaço intertrabecular encontrou-se reduzido e ocupado por tecido conjuntivo bem vascularizado e rico em fibroblastos nas áreas próximas às corticais, porém, nas áreas centrais, o tecido ósseo era menos compacto e apresentou-se com espaços intertrabeculares mais amplos. A crista óssea, tanto por vestibular quanto por palatina, apresentou tecido ósseo neoformado, preenchendo parcialmente áreas reabsorvidas, demonstrando atividade de remodelação óssea (Figura 5).

\subsubsection{Análise do subgrupo 14 dias}

Observou-se neoformação óssea não só restrita às proximidades das margens originais do alvéolo, mas por toda região alveolar, preenchendo quase 2/3 do alvéolo. Todos os espécimes apresentaram osso neoformado, circundado por matriz osteóide, rica em osteoblastos. A espessura do tecido conjuntivo que ocupava a parte central do defeito era menor que a do tecido ósseo original. $O$ tecido conjuntivo era bem vascularizado e rico em fibroblastos, com fibras colágenas orientadas. Não foram observadas células inflamatórias agudas (Figura 5). 
Figura 5: Fotomicrografias do Grupo Controle de 3, 7 e 14 dias pós extração dentária: TO - tecido ósseo, LP - ligamento periodontal, TC - tecido conjuntivo, FC - fibras colágenas, * (branco) - áreas hemorrágicas, * (preto) tecido inflamatório, V - vaso sanguíneo, setas - osteoclastos. Coloração de HE e Masson

\section{CONTROLE}

3 DIAS
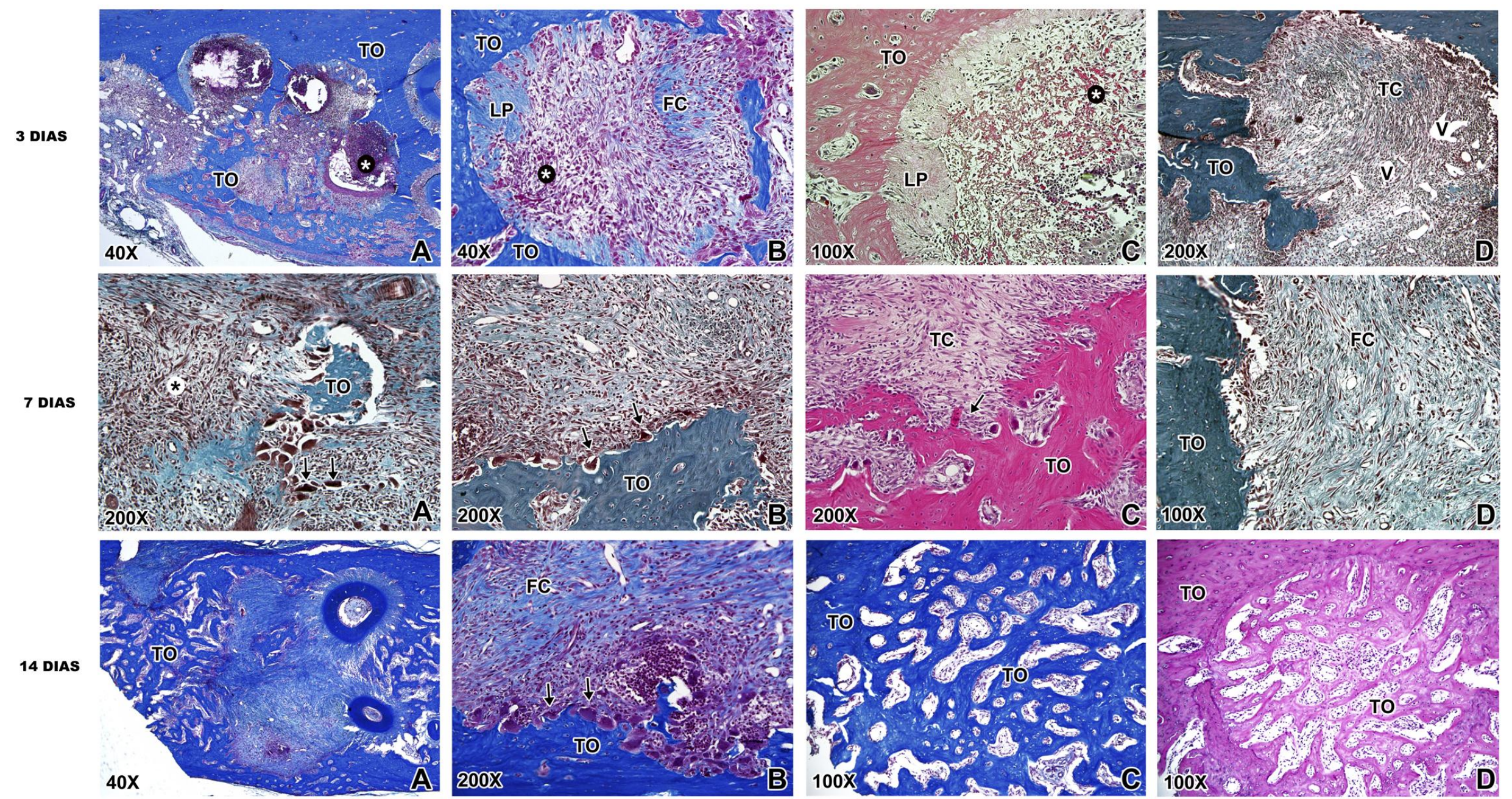



\subsubsection{Grupo Experimental I}

\subsubsection{Análise do subgrupo 3 dias}

Na região apical do alvéolo ainda havia resquício de processo inflamatório, porém a análise das cavidades das exodontias no terço médio evidenciou preenchimento por tecido conjuntivo altamente celularizado e vascularizado, com algumas áreas remanescentes de coágulo sanguíneo exibindo macrófagos, fibrina e hemácias em degeneração. A disposição do tecido conjuntivo mostrou variados graus de colagenização. $O$ ligamento periodontal remanescente aderido à parede óssea apresentou neovascularização e elevado número de fibroblastos jovens, principalmente junto ao terço médio alveolar, onde também foi observado grande quantidade de histiócitos e alguns linfócitos ao longo dos três terços alveolares. Nos terços médio e apical puderam ser observadas delgadas trabéculas ósseas neoformadas, com numerosos osteoblastos em suas bordas. A crista óssea alveolar apresentou remodelação óssea com a presença de osteoclastos, assim como no interior das cavidades medulares, em maior quantidade que o Grupo Controle (Figura 6).

\subsubsection{Análise do subgrupo 7 dias}

O epitélio da mucosa gengival recobria totalmente a região do alvéolo, e o tecido conjuntivo subjacente mostrou pequeno número de linfócitos e macrófagos. A formação vascular encontrou-se mais desenvolvida do que no Grupo Controle. Ao longo dos três terços, o alvéolo dental encontrou-se parcialmente preenchido por tecido conjuntivo neoformado bem vascularizado e altamente celularizado, rico em fibroblastos, pequenos vasos sanguíneos neoformados e raras células inflamatórias mononucleadas, ocupando áreas mais extensas quando comparado ao Grupo Controle. Os espécimes do grupo Experimental I exibiu um padrão de neoformação óssea, que contribui para o fechamento quase completo do alvéolo. Nos terços médio e apical, observou-se finas trabéculas ósseas com numerosos osteoblastos em suas bordas em quantidade superior ao Grupo Controle. Junto ao terço cervical, a neoformação óssea mostrou-se menos intensa, com trabéculas ósseas mais delgadas. A crista óssea alveolar teve as mesmas características observadas no grupo anterior (Figura 6). 


\subsubsection{Análise do subgrupo 14 dias}

O epitélio da mucosa gengival recobria o alvéolo dental em sua totalidade, estando o tecido conjuntivo subjacente bem desenvolvido, apresentando-se mais denso e mais vascularizado que no Grupo Controle. O alvéolo dental encontrou-se praticamente preenchido por tecido ósseo neoformado. Nos terços médio e apical evidenciou presença de grande quantidade de trabéculas ósseas neoformadas, espessas, defenidas e regulares com osteócitos preenchendo grandes lacunas no interior da matriz orgânica óssea e muitos osteoblastos na periferia. Partes das trabéculas neoformadas já esboçavam espaços medulares definidos, contendo em seu interior tecido conjuntivo vascularizado. Estas trabéculas estavam cercadas por tecido conjuntivo bem vascularizado, caracterizado por grande número de fibroblastos em diferenciação em meio à grande quantidade de vasos sanguíneos. A neoformação óssea foi vista, principalmente próximo às corticais alveolares (Figura $6)$. 
Figura 6: Fotomicrografias do Grupo Exp I de 3, 7 e 14 dias pós extração dentária: TO - tecido ósseo, LP - ligamento periodontal, TC - tecido conjuntivo, FC - fibras colágenas, ${ }^{*}$ (branco) - áreas hemorrágicas, ${ }^{*}$ (preto) tecido inflamatório, V - vaso sanguíneo, setas - osteoclastos. Coloração de HE e Masson

\section{EXPERIMENTAL I}

3 DIAS
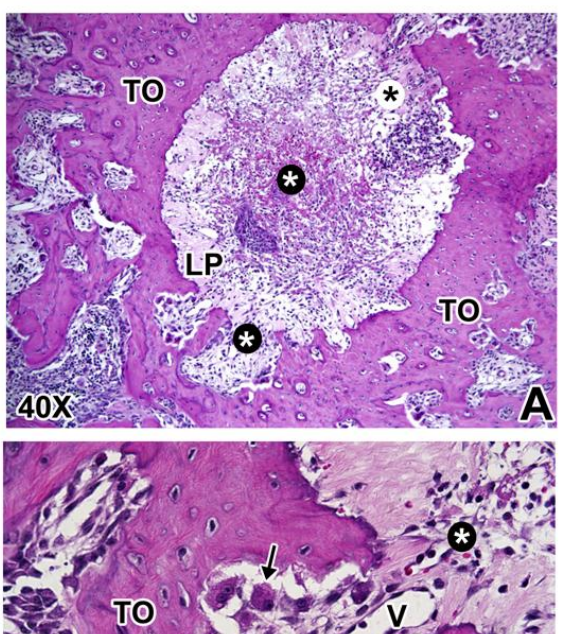

7 DIAS
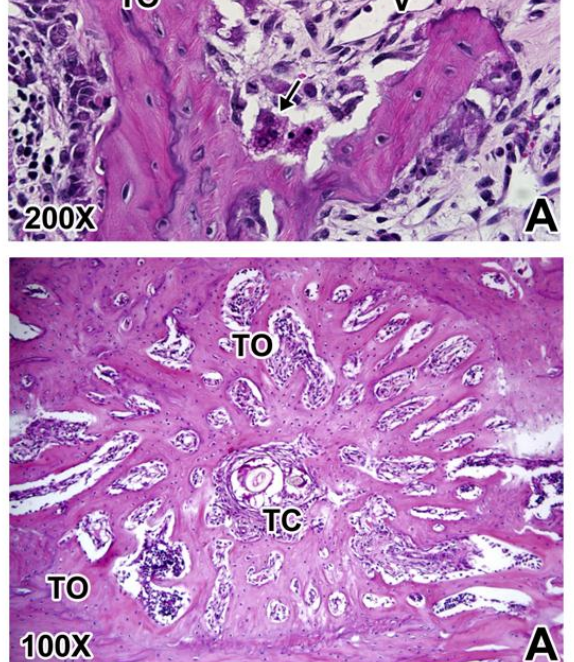
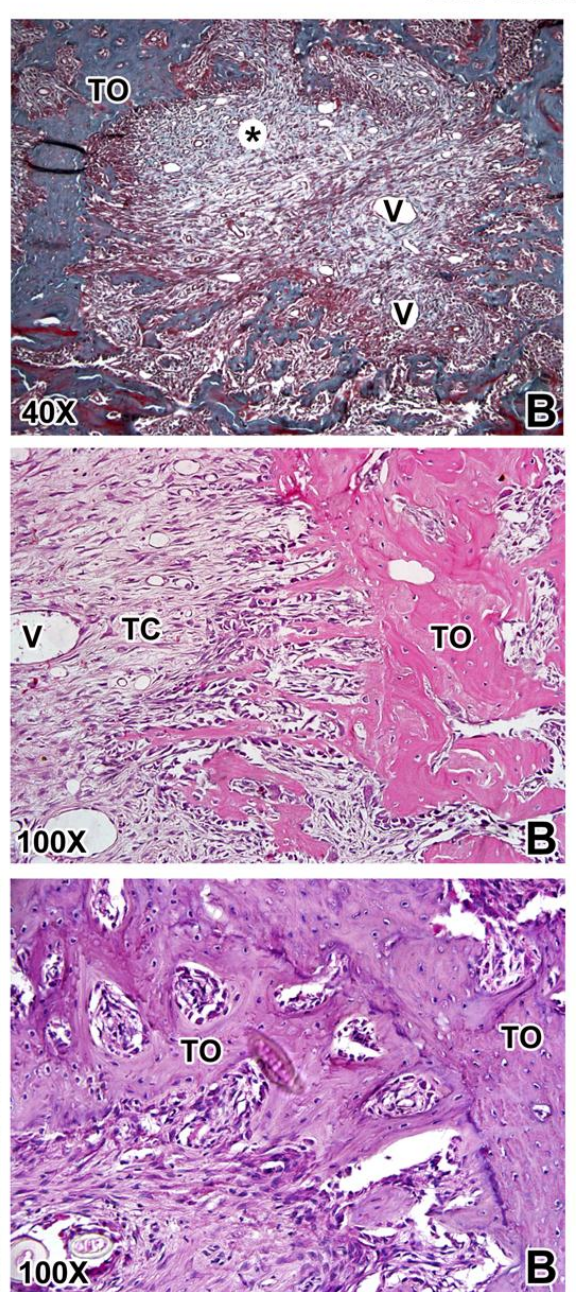
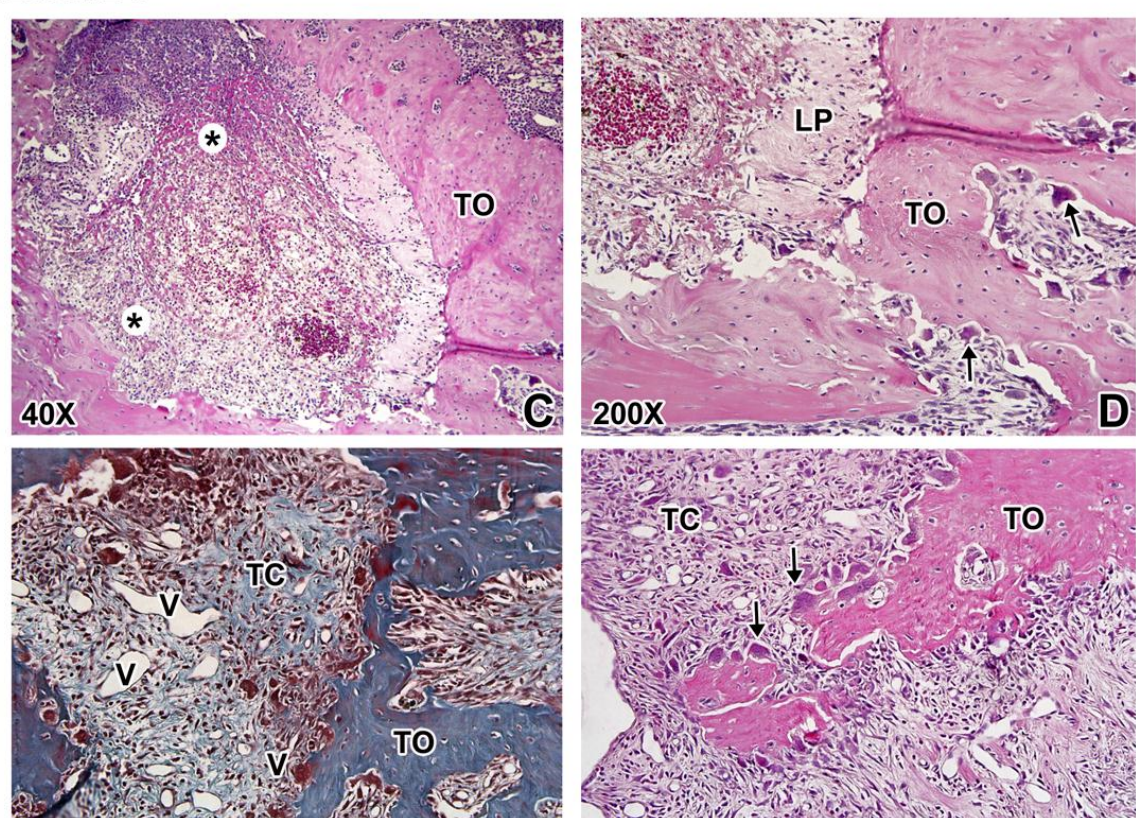

C 200x - a
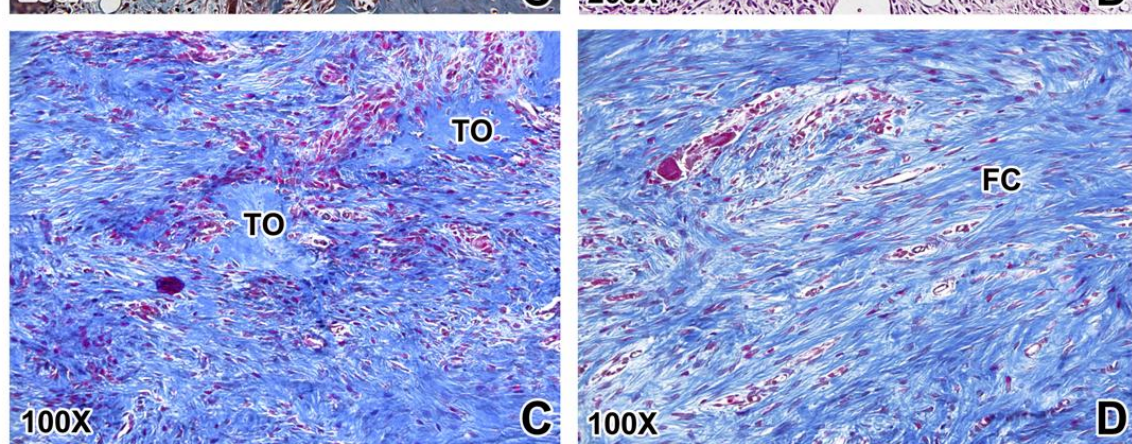

$100 \mathrm{X}-\mathrm{t}-\mathrm{s}$ 



\subsubsection{Grupo Experimental II}

\subsubsection{Análise do subgrupo 3 dias}

No epitélio da mucosa gengival ainda foi evidenciada discreta solução de continuidade. O tecido conjuntivo neoformado estava altamente celularizado com inúmeras células mononucleadas preenchendo a cavidade óssea, e alguns fibroblastos, principalmente nas proximidades da parede óssea alveolar, com algumas pequenas áreas de coágulo sanguíneo e pequenos vasos. Junto ao terço cervical e áreas mais afastadas da parede óssea, permaneceu um pequeno coágulo sanguíneo ainda sem organização reacional, exibiu numerosos macrófagos em seu interior. Osteoclastos ainda foram visualizados na parede alveolar. O terço cervical, junto à parede óssea alveolar, mostrou a presença de tecido conjuntivo sem diferenciação óssea (Figura 7).

\subsubsection{Análise do subgrupo 7 dias}

O epitélio da mucosa gengival ainda não recobria totalmente a região do alvéolo, e o tecido conjuntivo subjacente mostrou ainda alguns linfócitos e macrófagos, caracterizando um processo inflamatório. Uma neoformação óssea progrediu das bordas da ferida em direção à região central do alvéolo, porém, alguns focos de reabsorção óssea ativa foram observados demonstrando a intensa remodelação óssea na região. O tecido conjuntivo que ocupava as superfícies do defeito ósseo apresentava-se moderadamente denso, rico em vasos sanguíneos e provido de moderada quantidade de fibroblastos e discreto infiltrado inflamatório. (Figura 7).

\subsubsection{Análise do subgrupo 14 dias}

Observou-se tecido ósseo neoformado, circundado por matriz osteóide, restrito principalmente às margens originais do alvéolo dentário. As trabéculas neoformadas estavam circundadas por tecido conjuntivo denso, com fibras colágenas orientadas e elevado número de fibroblastos (Figura 7). 

Figura 7: Fotomicrografias do Grupo Exp II de 3, 7 e 14 dias pós-extração dentária: TO - tecido ósseo, LP - ligamento periodontal, TC - tecido conjuntivo, FC - fibras colágenas, * (branco) - áreas hemorrágicas, * (preto) tecido inflamatório, V - vaso sanguíneo, setas - osteoclastos. Coloração de HE e Masson.
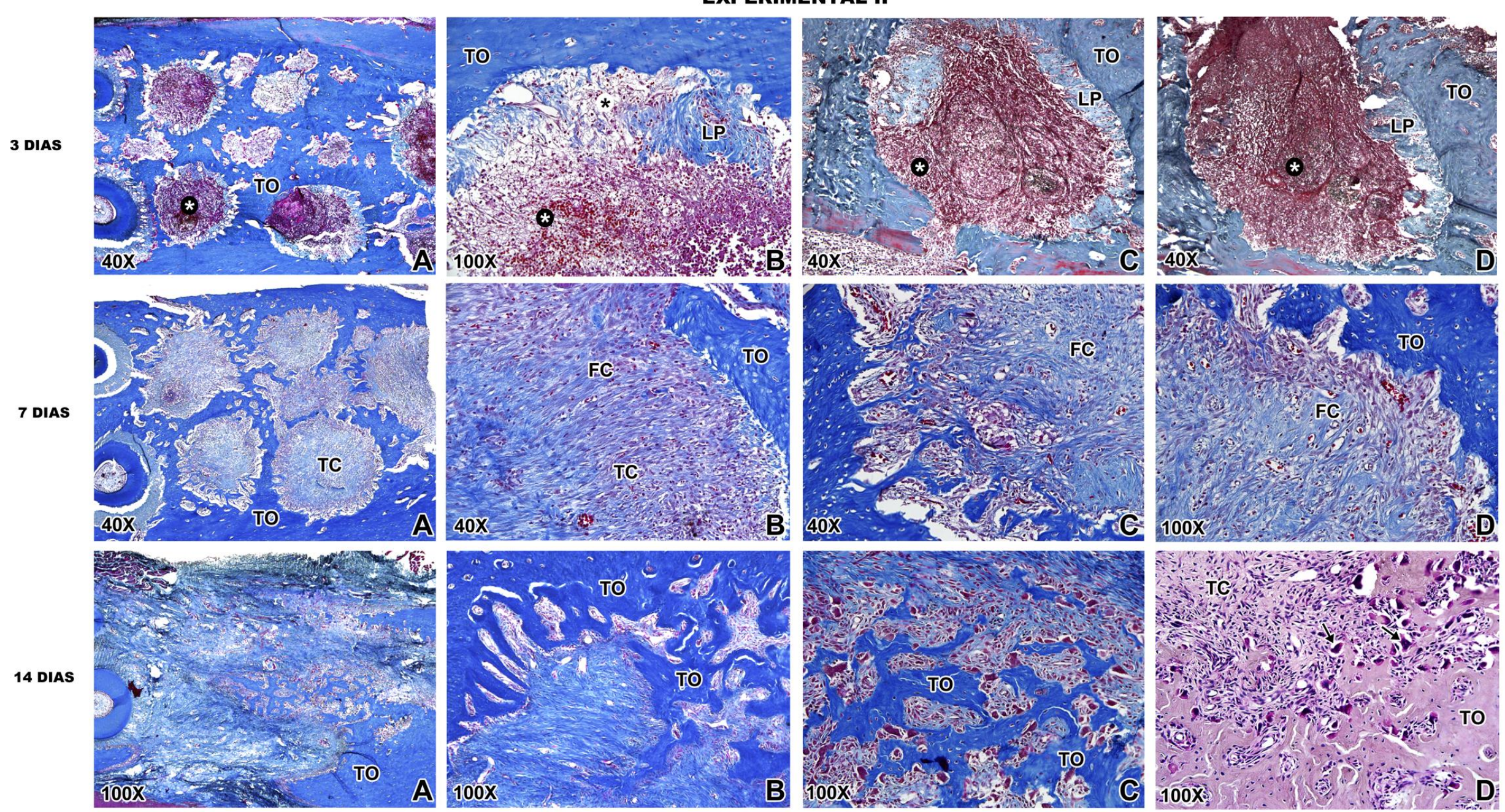



\subsubsection{Grupo Experimental III}

\subsubsection{Análise do subgrupo 3 dias}

Nos espécimes do Grupo Experimental III, observou-se uma estreita faixa de tecido ósseo neoformado confinada exclusivamente às bordas da ferida cirúrgica, principalmente no terço médio do alvéolo. Os alvéolos dentários, deste grupo, mostravam-se preenchidos em sua quase totalidade por tecido conjuntivo denso. Neste tecido, uma grande quantidade de fibras colágenas, orientadas paralelamente à superfície da ferida, abrigava raras células inflamatórias, grande quantidade de fibroblastos e alguns vasos sanguíneos. Finas e escassas trabéculas ósseas projetavam da parede alveolar em direção ao centro do alvéolo (Figura 8).

\subsubsection{Análise do subgrupo 7 dias}

Em inúmeros locais, evidenciou-se coágulo sanguíneo em organização com presença de macrófagos em seu interior. A neoformação óssea progrediu das bordas da ferida em direção ao seu centro, porém a quantidade e espessuras das trabéculas ósseas eram menores que o grupo Controle. O tecido ósseo neoformado propiciou o fechamento de mais de $1 / 3$ do alvéolo, sendo que no restante do alvéolo mostrava-se ocupado por tecido conjuntivo denso. Este tecido mostrava-se composto por grande quantidade de fibras colágenas, entre as quais se observava moderada quantidade de fibroblastos e vasos sanguíneos (Figura 8).

\subsubsection{Análise do subgrupo 14 dias}

Não foram observadas células inflamatórias agudas. As trabéculas neoformadas projetavam-se em direção a parte central do alvéolo, preenchendo aproximadamente $3 / 4$ da área. O tecido ósseo estava circundado por tecido conjuntivo denso, com fibras colágenas orientadas e elevado número de fibroblastos (Figura 8). 

Figura 8: Fotomicrografias do Grupo Exp III de 3, 7 e 14 dias pós extração dentária: TO - tecido ósseo, LP - ligamento periodontal, TC - tecido conjuntivo, FC - fibras colágenas, * (branco) - áreas hemorrágicas, * (preto) tecido inflamatório, V - vaso sanguíneo, setas - osteoclastos. Coloração de HE e Masson.

\section{EXPERIMENTAL III}

3 DIAS
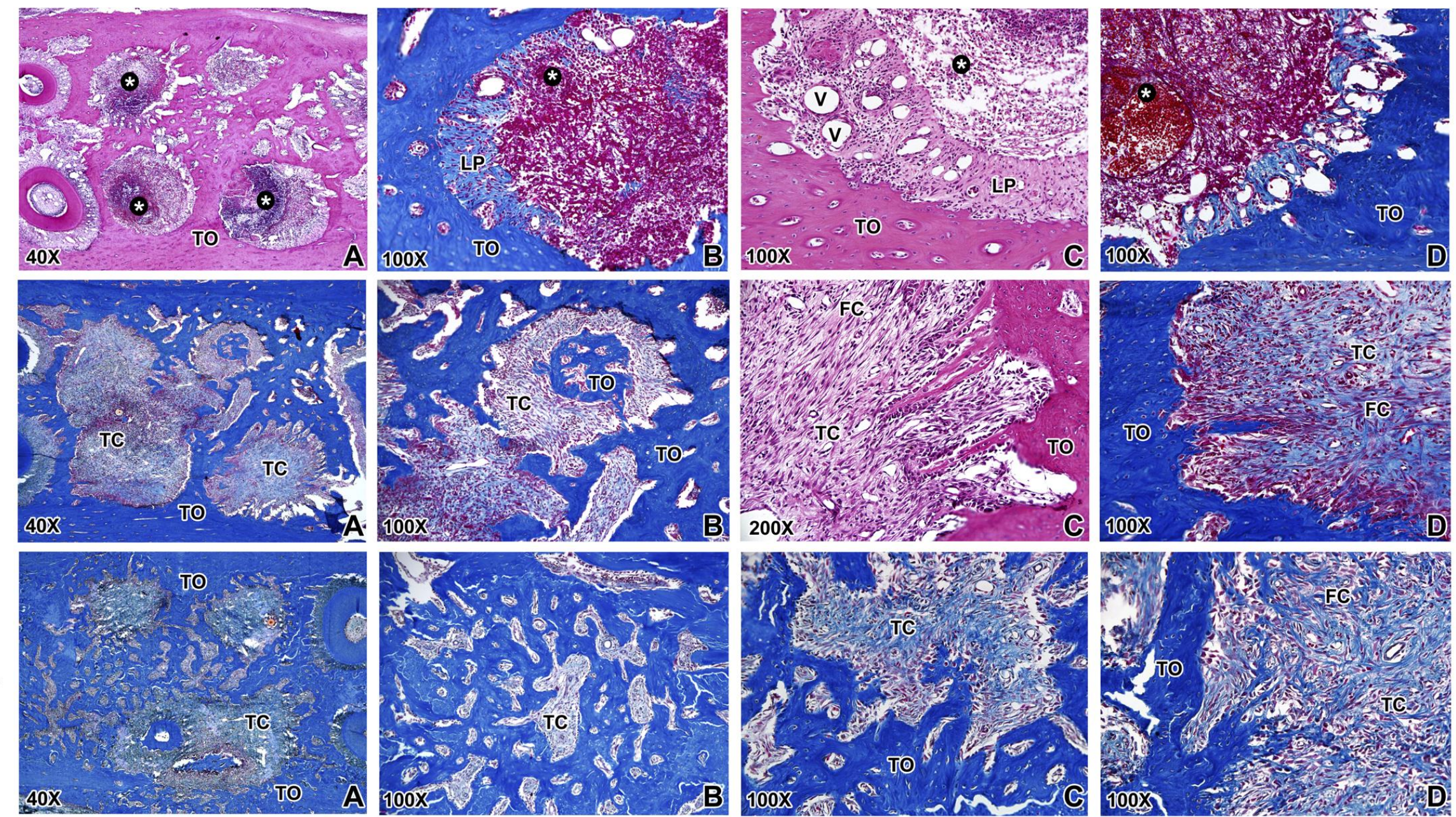



\subsection{Resultados Histométricos}

As médias e os desvios-padrão de osso neo-formado para cada grupo, bem como os resultados da comparação entre eles, estão apresentados na Figura 9 e 10, Quadro 1 e Tabela 3.

\section{Formação óssea:}

O teste Kappa indicou alto nível de concordância nas medidas de neoformação ósse de $94 \%$. A quantidade de formação óssea foi obtida a partir da porcentagem de osso neoformado em relação à área total do alvéolo. Aos 3 dias a análise histométrica da neoformação óssea na área do alvéolo foi significativamente maior no grupo experimental I $(p<0,01)$ em relação ao Grupo Controle, sendo que nos grupos Exp II e III não houve diferença estatística neste período (GC 9,29\% \pm

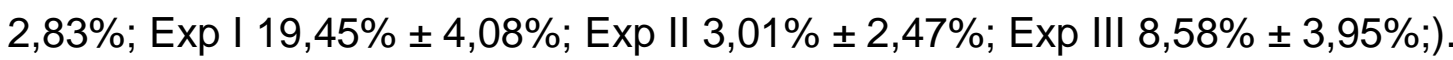

Aos 7 dias o comportamento da neo-formação foi semelhante aos 3 dias, porém no Grupo Exp I o aumento foi significativo $(p<0,001)$ e no Exp II a redução em relação ao controle também foi significativo $(p<0,01)$. A remodelação óssea média nestes grupos foram GC 22,48\% $\pm 9,41$; Exp । 58,87\% \pm 8,07\%; Exp || 7,07\% \pm $3,36 \%$ e Exp III 16,08\% $\pm 6,79 \%$.

Aos 14 dias houve aumento significativo entre o Grupo Controle e Exp I $(p<0,01)$ (GC 61,13\% $\pm 3,70 \%$ versus Exp I 86,96\% $\pm 13,97 \%$ ), e entre o Grupo Controle e Exp II houve uma redução significativa $(p<0,01)(G C 61,13 \% \pm 3,70 \%$ versus Exp II 25,77\% $\pm 17,43$.

Figura 9: Expressão da percentagem média e desvio padrão da formação óssea no Grupo Controle e Experimentais. Os dados correspondem a 14 dias de experimento. ${ }^{*} \mathrm{p}<0,05 ;{ }^{* *} \mathrm{p}<0,01$; ${ }^{* \star *} p<0,001 ; p>0,05=$ não significativo.

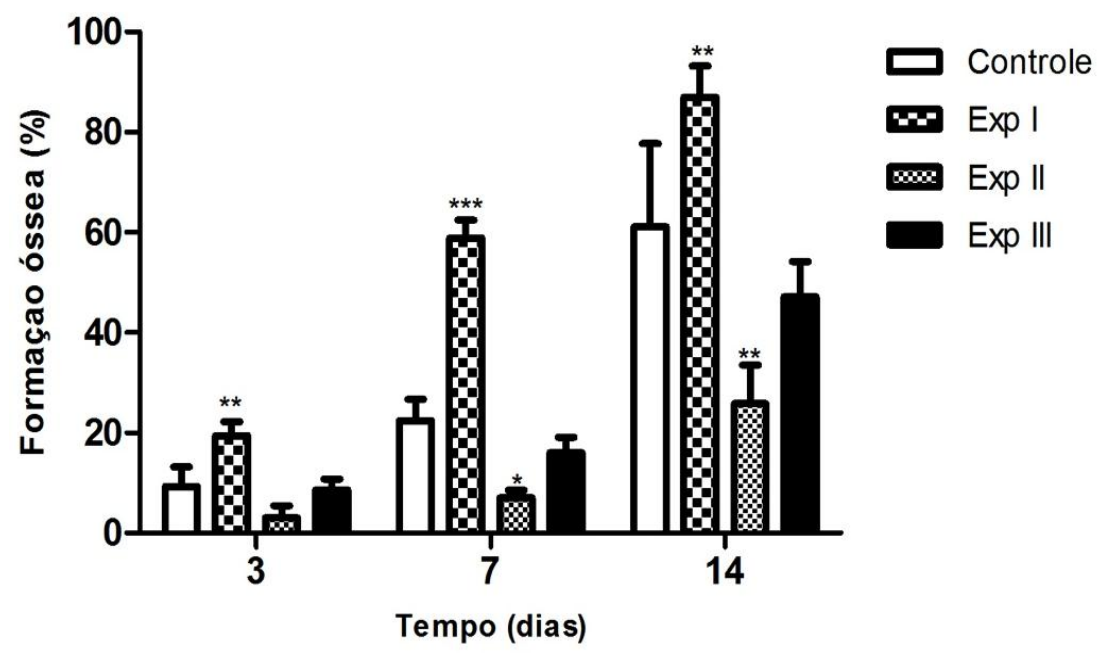


Quadro 1: Análise de variância (ANOVA) e teste de TUKEY dos resultados histomorfométricos, referentes à percentagem de trabéculas ósseas formadas entre o Grupo Controle, Laser de baixa potência (LBP) e Fumaça de cigarro (FC). Nível de significância estatística $(p<0,05)$.

\begin{tabular}{|c|c|c|c|}
\hline \multirow{2}{*}{ Grupos } & \multicolumn{3}{|c|}{ NíVEL DE SIGNIFICÂNCIA ESTATÍSTICA (P) } \\
\cline { 2 - 4 } & 3 dias & 7 dias & 14 dias \\
\hline $\begin{array}{c}\text { Controle } \\
\mathbf{X} \\
\text { Exp I }\end{array}$ & $p<0,01$ & $p<0,001$ & $p<0,01$ \\
\hline $\begin{array}{c}\text { Controle } \\
\mathbf{X} \\
\text { Exp II }\end{array}$ & $p>0,05$ & $p<0,01$ & $p<0,01$ \\
\hline $\begin{array}{c}\text { Controle } \\
\mathbf{X} \\
\text { Exp III }\end{array}$ & $p>0,05$ & $p>0,05$ & $p>0,05$ \\
\hline
\end{tabular}

Figura 10: Expressão da percentagem média e desvio padrão da formação óssea nos Grupos Controle e Experimentais. Os dados correspondem a 14 dias de experimento. ${ }^{*} \mathrm{p}<0,05 ;{ }^{* *} \mathrm{p}<0,01 ;{ }^{* * *} \mathrm{p}<0,001$; $p>0,05=$ não significativo.

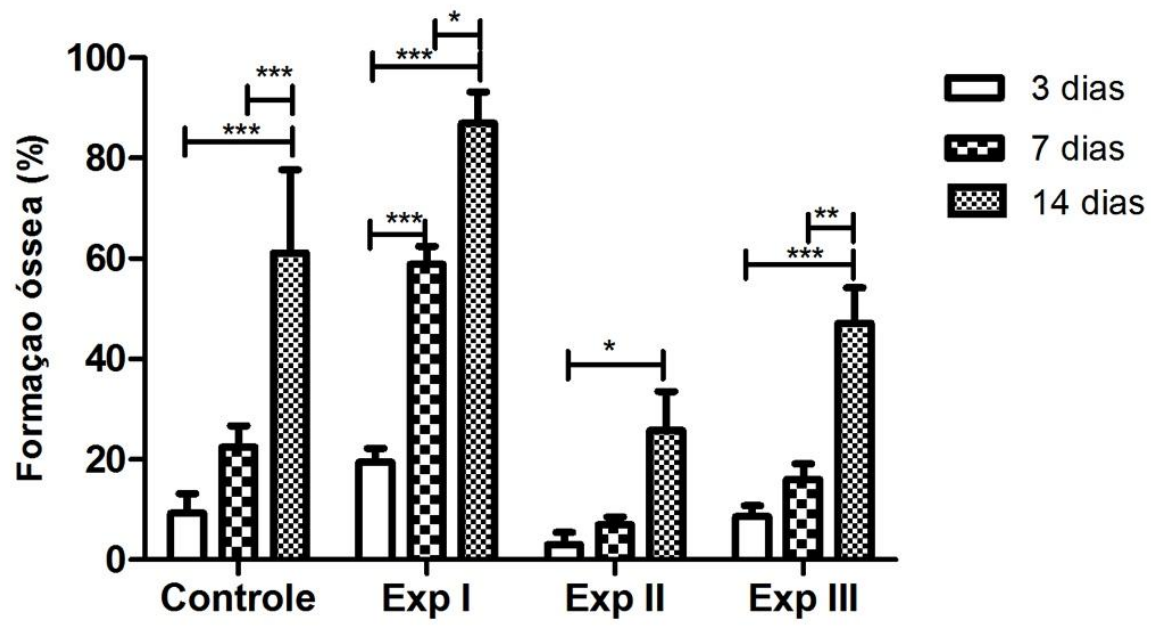

Tabela 3: Porcentagem média da Área de Osso Neoformado (ONF) na área do alvéolo, com comparação entre os grupos.

\begin{tabular}{cccccccc}
\hline Grupo & $\mathbf{n}$ & $\begin{array}{c}\text { Médias } \\
\text { de ONF (\%) } \\
\mathbf{3} \text { dias }\end{array}$ & $\begin{array}{c}\text { DP } \\
\mathbf{3} \text { dias }\end{array}$ & $\begin{array}{c}\text { Médias } \\
\text { de ONF (\%) } \\
\mathbf{7} \text { dias }\end{array}$ & $\begin{array}{c}\text { DP } \\
\mathbf{7} \text { dias }\end{array}$ & $\begin{array}{c}\text { Médias } \\
\text { de ONF (\%) } \\
\mathbf{1 4} \text { dias }\end{array}$ & $\begin{array}{c}\text { DP padrão } \\
\mathbf{1 4} \text { dias }\end{array}$ \\
\hline Controle & 6 & 9,29 & $\pm 8,83$ & 22,48 & $\pm 9,41$ & 61,13 & $\pm 27,02$ \\
\hline Exp I & 6 & 19,45 & $\pm 6,08$ & 58,87 & $\pm 8,07$ & 86,96 & $\pm 13,97$ \\
\hline Exp II & 6 & 3,01 & $\pm 5,04$ & 7,07 & $\pm 3,36$ & 25,77 & $\pm 17,43$ \\
\hline Exp III & 6 & 8,48 & $\pm 4,93$ & 16,08 & $\pm 6,70$ & 47,09 & $\pm 12,94$ \\
\hline
\end{tabular}




\section{3.qRT-PCR}

Observou-se diferença estatisticamente significante em relação ao tempo e tratamento quando foi analisada a expressão relativa dos RNAm dos genes Bmp-2 (Bmp2), Bsp (Ibsp), Opn (Spp1), Onc (Sparc), Occ (Bglap), Rank (Tnfrsf11a), RankI (Tnfsf11) e Opg (Tnfrsf11b), durante os diferentes tempos e grupos (tratamento) de avaliação $(p<0,05)$. Os resultados para cada gene de interesse envolvidos no processo de remodelação óssea estão representados nas Figuras de 11 (página 100) a 18 (página 107). 


\section{a) Expressão de RNAm de Bmp2}

$\mathrm{Na}$ análise da expressão gênica nos diferentes grupos de estudo, notou-se que no período de 3 dias, houve diferença estatística na expressão do gene $B m p-2$, sendo que no Exp I houve um aumento significativo e no Exp II uma redução significativa $(p<0,01)$ e, no Exp III não houve diferença estatística, quando comparado ao Grupo Controle. O mesmo comportamento foi verificado no período de 7 dias. Aos 14 dias, houve diferença estatística na expressão do gene Bmp-2, sendo que no Exp I houve um aumento significativo e no Exp II uma redução significativa $(p<0,05)$ e, no Exp III não houve diferença estatística, quando comparado ao Grupo Controle (Figura 11A).

Quando comparou-se os Grupos Experimentais entre si, houve uma redução na expressão relativa do RNAm do gene Bmp-2 no grupo Exp II e Exp III comparado ao grupo Exp I $(p<0,001)$ (Figura 11A).

Ao se analisar os tempos de estudos, pode-se observar que houve uma maior expressão de Bmp-2 no grupo Exp I em todos os períodos. O pico de maior expressão de Bmp-2 foi no grupo Exp I aos 3 dias, seguido do período de 7 dias (Figura 11B ).

Figura 11: (A) Expressão do RNAm do gene Bmp2 nos diferentes grupos em relação ao Grupo Controle e (B) Expressão do RNAm do gene Bmp2 nos diferentes grupos experimentais. Os gráficos mostram a média, desvio padrão e ${ }^{*} p<0,05 ;{ }^{* *} p<0,01 ;{ }^{* * *} p<0,001$.
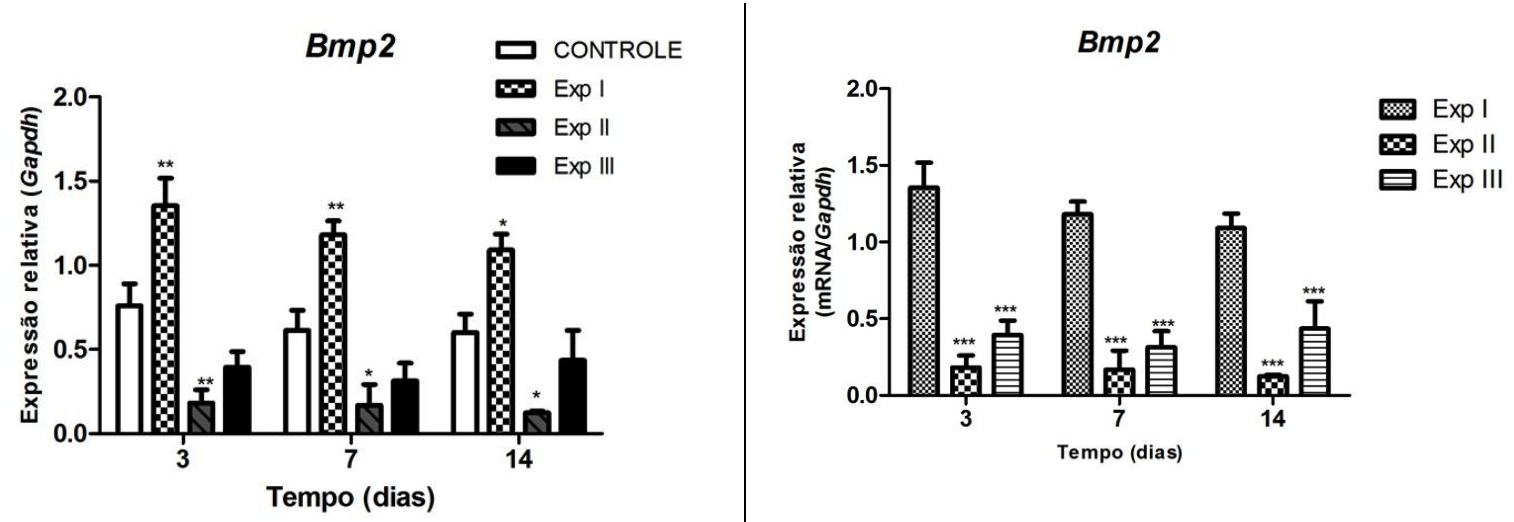


\section{b) Expressão de RNAm de Bsp (Ibsp)}

$\mathrm{Na}$ análise da expressão gênica, o grupo Exp I apresentou estímulo na expressão de mRNA para o gene lbsp (Bsp) quando comparado ao grupo Controle no período de $3(p<0,01), 7(p<0,001)$ e $14(p<0,05)$ dias. No Grupo Exp II houve uma redução significativa aos 3 e $14(p<0,05)$ dias comparado ao Grupo Controle. No Grupo Exp III houve uma diminuição da expressão gênica de Bsp em todos os períodos em relação ao Controle, porém não significativa (Figura 12A).

Quando comparou-se os Grupos Experimentais entre si, houve uma redução na expressão relativa do RNAm do gene Bsp no grupo Exp II e Exp III comparado ao grupo Exp I ( $p<0,001)$ (Figura 12A).

Ao se analisar os tempos de estudo, pode-se observar um estímulo pico na expressão de lbsp no grupo Exp I aos 3 dias $(p<0,01)$, seguido ao 7 dias $(p<0,001)$, e a menor expressão aos 14 dias $(p<0,05)$ (Figura 12B).

Figura 12: (A) Expressão do RNAm do gene Bsp nos diferentes grupos em relação ao Grupo Controle e (B) Expressão do RNAm do gene Bsp nos diferentes grupos experimentais. Os gráficos mostram a média, desvio padrão e ${ }^{*} p<0,05 ;{ }^{* *} p<0,01 ;{ }^{* *} p<0,001$.
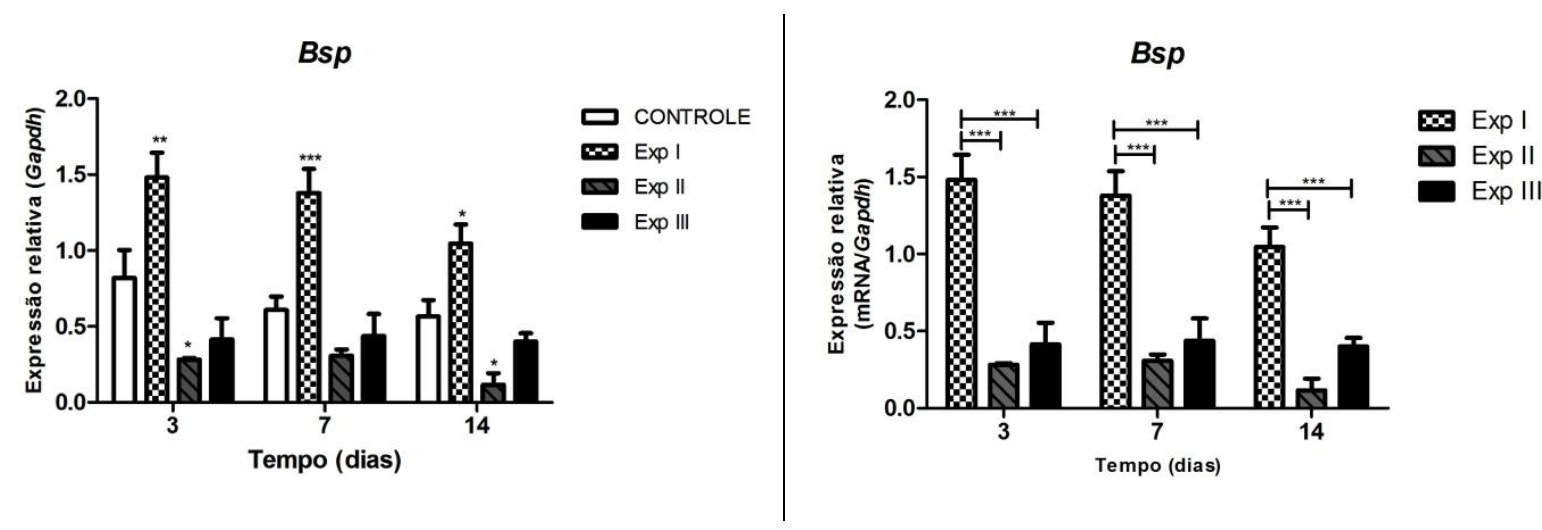


\section{c) Expressão de RNAm de Opn (Spp1)}

Ao se analisar o Grupo Exp I com o Controle nos diferentes tempos de experimento, pode-se notar que não houve diferença estatística entre esses dois grupos. No Grupo Exp II houve uma diminuição estatisticamente diferente entre esse grupo e o Controle em todos os períodos, mostrando que a fumaça de cigarro interferiu na expressão desse gene. O mesmo aconteceu no Grupo Exp III, onde a expressão do gene sofreu influência da fumaça de cigarro em todos os tempos de observação. (Figura 13A).

Ao se analisar os tempos de estudos, pode-se observar que houve uma maior expressão de Opn no grupo Controle e Exp I em todos os períodos, sem diferença estatística entre esses dois grupos. O pico de maior expressão de Opn foi aos 3 dias do experimento (Figura 13A).

Quando comparou-se os Grupos Experimentais entre si, houve uma redução significativa na expressão relativa do RNAm do gene Opn no grupo Exp II e Exp III comparado ao grupo Exp I ( $p<0,001)$. (Figura 13B).

Figura 13: (A) Expressão do RNAm do gene Opn nos diferentes grupos em relação ao Grupo Controle e (B) Expressão do RNAm do gene Opn nos diferentes grupos experimentais. Os gráficos mostram a média, desvio padrão $e^{*} p<0,05 ;{ }^{* *} p<0,01 ;{ }^{* * *} p<0,001$.
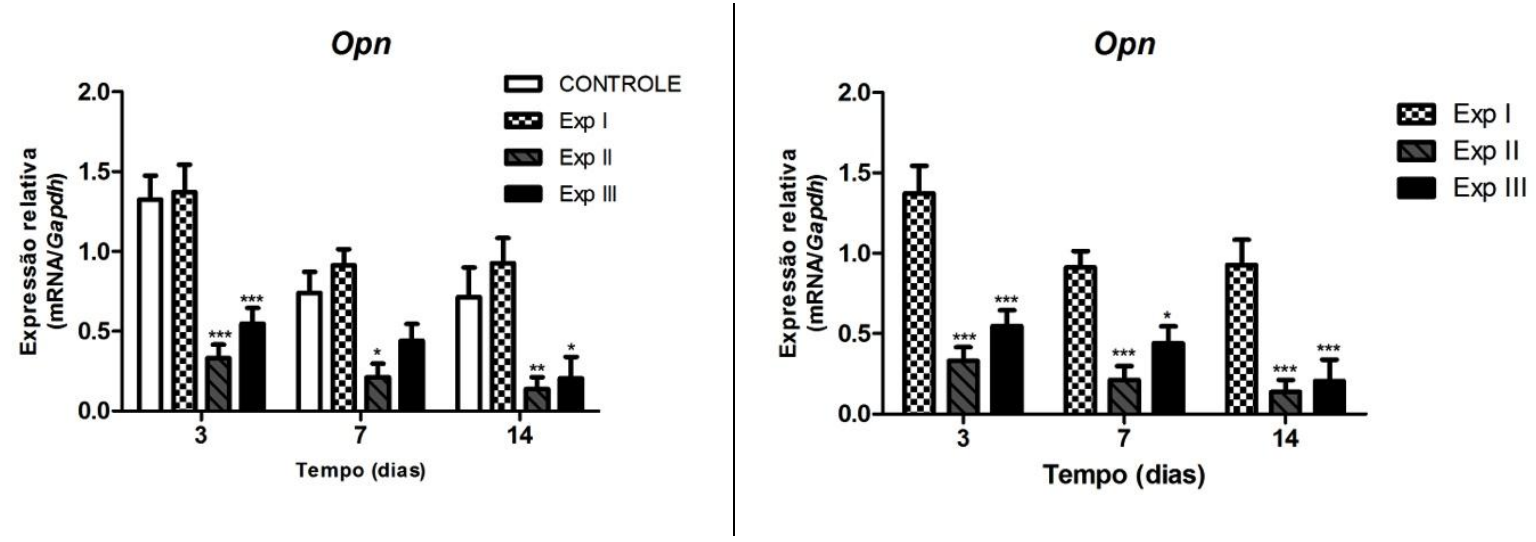


\section{d) Expressão de RNAm de Onc (Sparc)}

$\mathrm{Na}$ análise gênica no período de 3 e 7 dias de remodelação óssea, o grupo Exp I apresentou maior expressão de mRNA para o gene Onc quando comparado ao Controle $(p<0,01)$, porém o Grupo Exp II e III apresentaram uma diminuição significativa comparado ao grupo Controle neste períodos iniciais $(p<0,05)$. No período de 14 dias observou-se o mesmo padrão inicial porém sem significância estatística $(p>0,05)$, isto é, houve uma menor expressão relativa do gene de interesse nesses grupos comparado ao grupo Controle. Avaliando-se o período mais tardio do processo de remodelação óssea, pode-se observar que houve uma maior expressão do gene de interesse no grupo Exp I comparado ao grupo Controle, porém não houve diferença estatística (Figura 14A).

Quando comparou-se os Grupos Experimentais entre si, houve uma redução na expressão relativa do RNAm do gene Onc no grupo Exp II e Exp III comparado ao grupo Exp I $(p<0,001)$ (Figura 14B).

Ainda na análise gênica, quando avaliou-se o tempo, pode-se observar que o grupo Exp I apresentou estímulo do gene de intresse aos 3 e 7 dias quando comparado ao tempo de 14 dias de avaliação $(p<0,05)$. Por outro lado, os grupos Exp II e III apresentaram uma inibição gênica em todos os tempos analisados $(p<0,05)$ (Figura 14B).

Figura 14: (A) Expressão do RNAm do gene Onc nos diferentes grupos em relação ao Grupo Controle e (B) Expressão do RNAm do gene Onc nos diferentes grupos experimentais. Os gráficos mostram a média, desvio padrão ${ }^{*} p<0,05 ;{ }^{* *} p<0,01 ;{ }^{* *} p<0,001$.
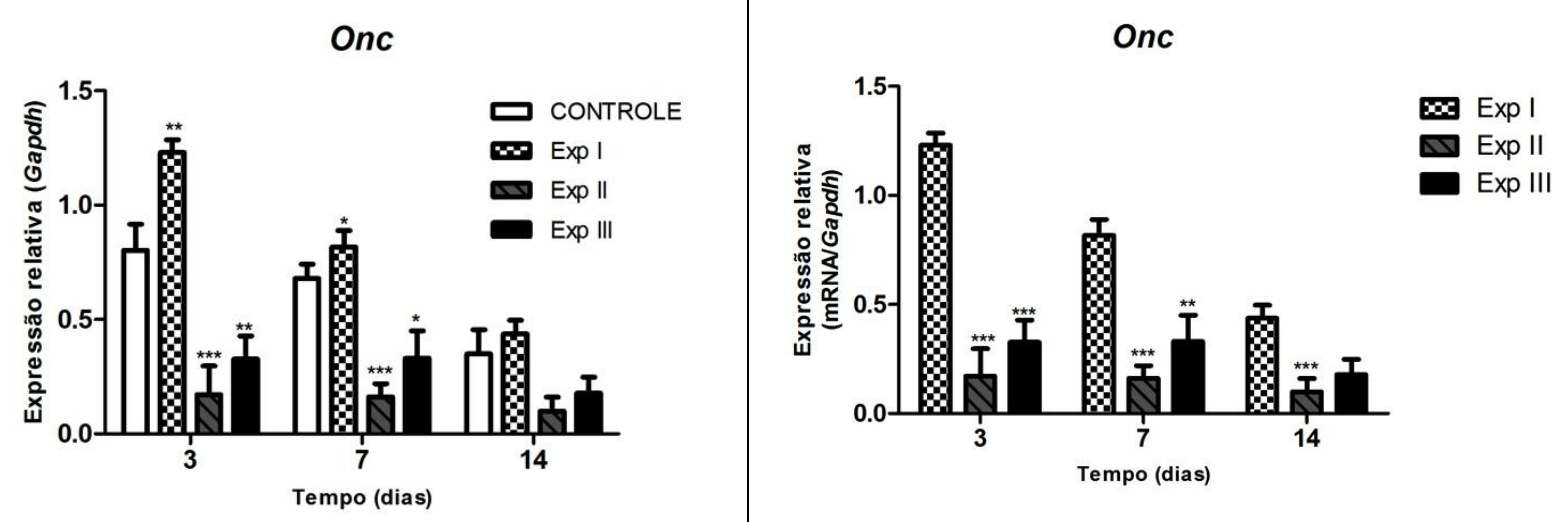


\section{e) Expressão de RNAm de Occ (Bglap)}

$\mathrm{Na}$ análise gênica, no período de 3, 7 e 14 dias o grupo Exp I apresentou a maior expressão de mRNA para o gene Occ quando comparado aos demais grupos, sendo estatísticamente significativo em relação a eles. $(p<0,05)$. No Grupo Exp II observou-se uma menor expressão do gene de interesse em todos os períodos comparando-se ao grupo Controle $(p<0,05)$. No Grupo Exp III, observou-se uma redução na expressão do gene de interesse em todos os períodos comparado ao grupo Controle, porém, essa redução só foi significativa aos 3 dias $(p<0,05)$ (Figura $15 A)$.

Quando avaliou-se o tempo, pode-se observar que o grupo Exp I apresentou estímulo do gene de intresse aos 3 e 7 dias quando comparado ao tempo de 14 dias de avaliação $(p<0,05)$. Por outro lado, os grupos Exp II e III apresentaram uma inibição gênica em todos os tempo analisados $(p<0,05)$ (Figura $15 A)$.

Quando comparou-se os Grupos Experimentais entre si, houve uma redução na expressão relativa do RNAm do gene Onc no grupo Exp II e Exp III comparado ao grupo Exp I em todos os períodos ( $p<0,001)$ (Figura 15B).

Figura 15: (A) Expressão do RNAm do gene Occ nos diferentes grupos em relação ao Grupo Controle e (B) Expressão do RNAm do gene Occ nos diferentes grupos experimentais. Os gráficos mostram a média, desvio padrão e ${ }^{*} p<0,05 ;{ }^{* *} p<0,01 ;{ }^{* * *} p<0,001$.
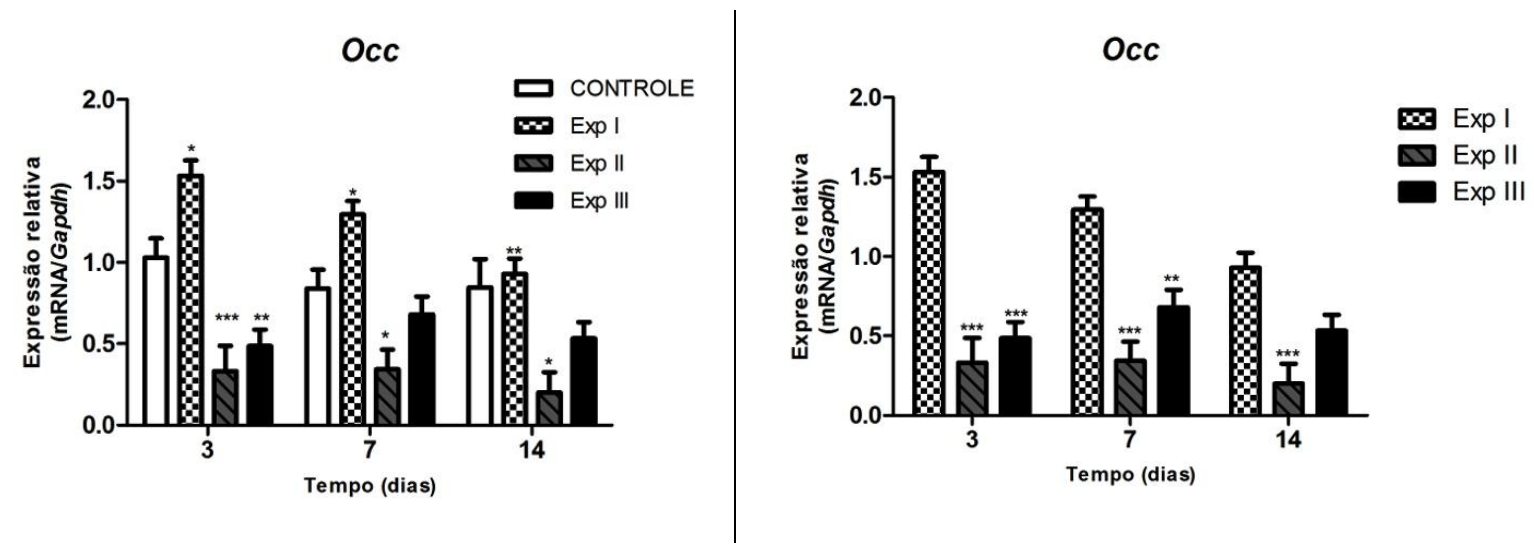


\section{f) Expressão de RNAm de Rank (Tnfrsf11a)}

No período de 3 dias o grupo Exp I apresentou maior expressão de mRNA para o gene Rank quando comparado ao grupo Controle $(p<0,001)$. Nos demais tempos não houve diferença entre esses dois grupos $(p>0,05)$ (Figura 16A).

Ao se avaliar o tempo para os diferentes grupos, observou-se para o grupo Exp I maior expressão gênica aos 3 dias comparado aos tempos de 7 e 14 dias $(p<0,05)$. Para os grupos Exp II e Exp III, notou-se uma redução significativa em relação ao Grupo Controle $(p<0,05)$ (Figura 16A).

Quando comparou-se os Grupos Experimentais entre si, houve uma redução na expressão relativa do RNAm do gene Rank nos grupos Exp II e Exp III comparado ao grupo Exp I em todos os períodos, sendo esta redução significativa aos 3 e 7 dias $(p<0,001)$ (Figura 16B).

Figura 16: (A) Expressão do RNAm do gene Rank nos diferentes grupos em relação ao Grupo Controle e (B) Expressão do RNAm do gene Rank nos diferentes grupos experimentais. Os gráficos mostram a média, desvio padrão e ${ }^{*} p<0,05 ;{ }^{* *} p<0,01 ;{ }^{* * *} p<0,001$.
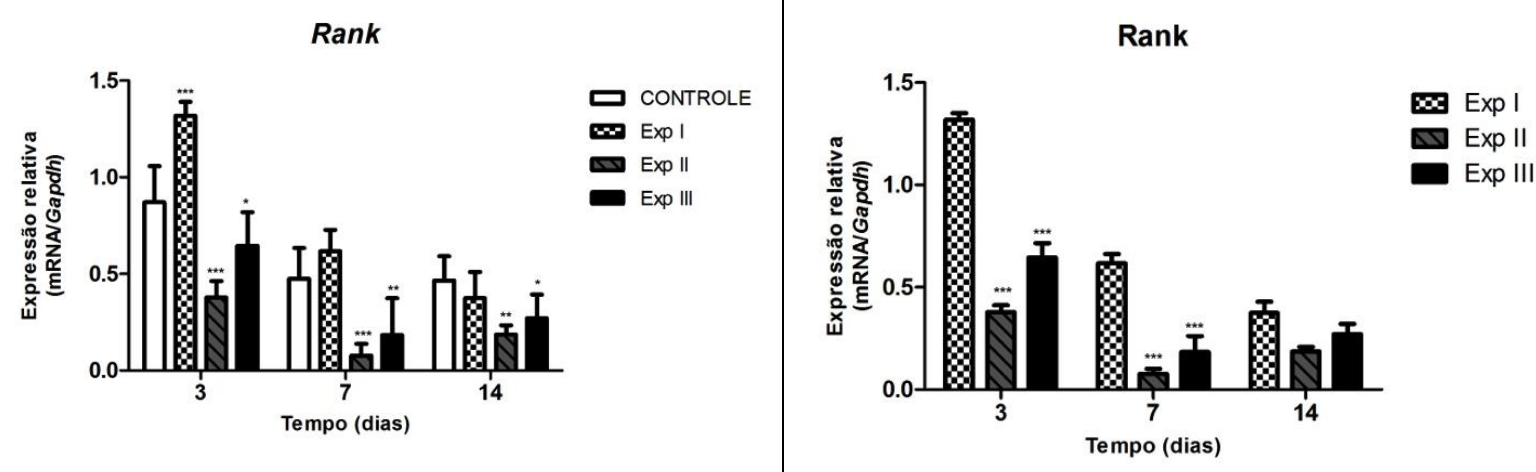


\section{g) Expressão de RNAm de Rankl (Tnfsf11)}

$\mathrm{Na}$ análise gênica, o grupo Exp I apresentou maior expressão de mRNA para o gene Rankl quando comparado ao grupo Controle, sendo este aumento significativo apenas aos 7 dias $(p<0,05)$. Os grupos Exp II e Exp III tiveram uma redução expressiva e significativa estatísticamente em todos os períodos analisados em relação ao grupo Controle $(p<0,001)$ (Figura 17A).

Ao se avaliar o tempo para os diferentes grupos, observou-se para o grupo Exp I maior expressão gênica aos 3 e 7 dias dias comparado ao tempo de 14 dias $(p<0,05)$. Para o grupo Exp II, notou-se uma menor expressão em todos os períodos analisados $(p<0,001)$ (Figura 17A).

Quando comparou-se os Grupos Experimentais entre si, houve uma redução na expressão relativa do RNAm do gene Rank nos grupos Exp II e Exp III comparado ao grupo Exp I em todos os períodos, sendo esta redução significativa aos 3 e 7 dias $(p<0,001)$ (Figura 17B).

Figura 17: (A) Expressão do RNAm do gene Rankl nos diferentes grupos em relação ao Grupo Controle e (B) Expressão do RNAm do gene Rankl nos diferentes grupos experimentais. Os gráficos mostram a média, desvio padrão e ${ }^{*} p<0,05 ;{ }^{* *} p<0,01 ;{ }^{* * *} p<0,001$.
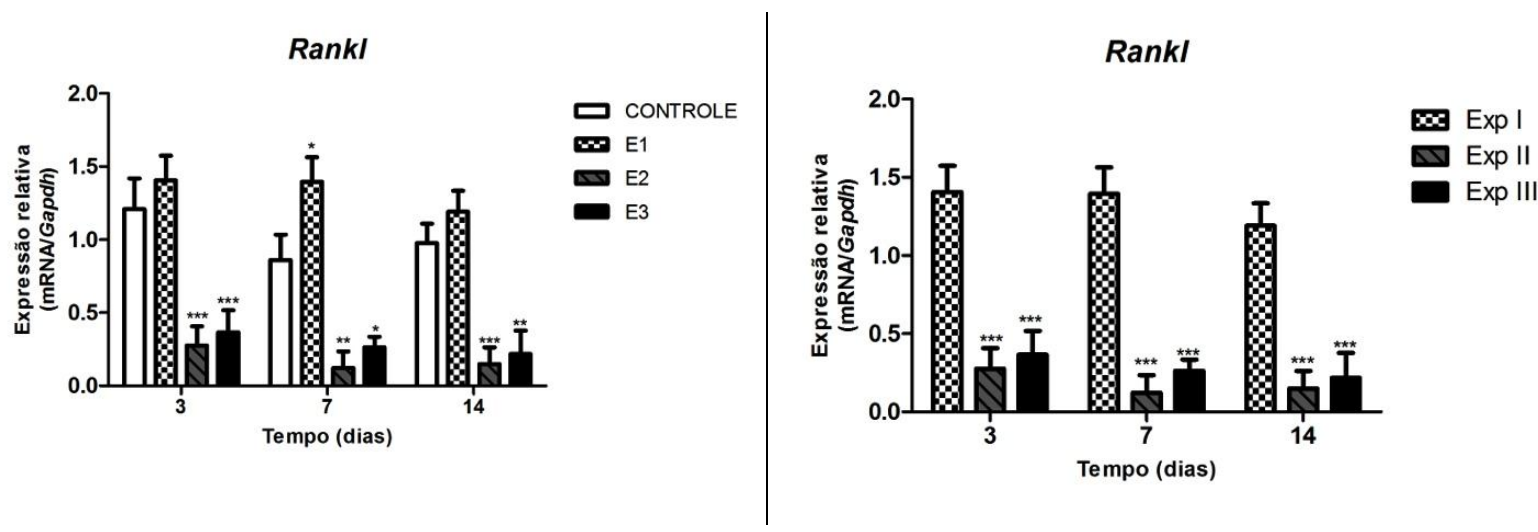


\section{h) Expressão de RNAm de Opg (Tnfrsf11b)}

$\mathrm{Na}$ análise gênica, o grupo Exp I apresentou um estímulo na expressão de mRNA para o gene Opg quando comparado ao grupo Controle em todos os períodos analisados $(p<0,05)$. O Grupo Exp II foi o que apresentou a menor expressão gênica, estatisticamente significativa em relação ao Controle. No Grupo Exp III, a expressão gênica também foi menor, porém esta diminuição só foi estatisticamente significativa no período de 3 dias $(p<0,001)$ (Figura 18A).

Avaliando-se o tempo para os diferentes grupos, pode-se notar que o grupo Exp I apresentou maior estímulo proteico para Opg em todos os períodos (Figura $18 A)$.

Quando comparou-se os Grupos Experimentais entre si, houve uma redução significativa na expressão relativa do RNAm do gene Opg nos grupos Exp II e Exp III comparado ao grupo Exp I em todos os períodos $(p<0,001)$ (Figura 18B).

Figura 18: (A) Expressão do RNAm do gene Opg nos diferentes grupos em relação ao Grupo Controle e (B) Expressão do RNAm do gene Opg nos diferentes grupos experimentais. Os gráficos mostram a média, desvio padrão e ${ }^{*} p<0,05 ;{ }^{* *} p<0,01 ;{ }^{* * *} p<0,001$
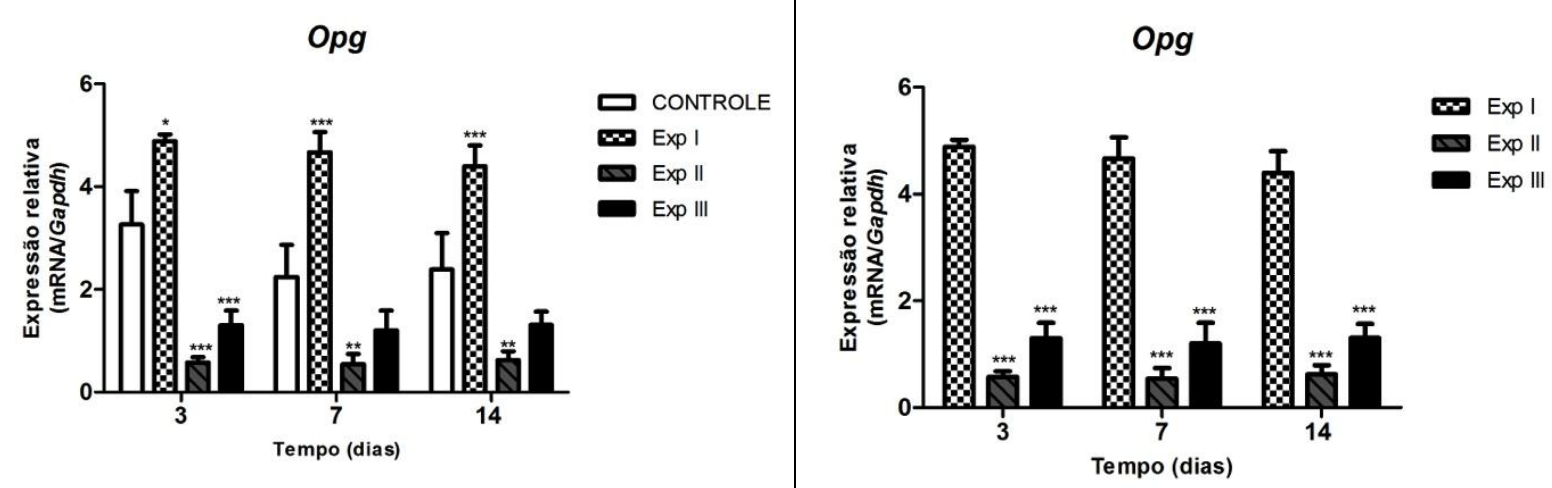

5. Discussão 



\section{DISCUSSÃO}

Embora o índice de fumantes passivos no Brasil tenha caído 42,5\% em oito anos, de 12,7\% em 2009 para 7,3\% em 2016 (Ministério da Saúde), o tabagismo passivo foi considerado pela Organização Mundial de Saúde (OMS), em 2013, a 3 maior causa de morte evitável no mundo, perdendo apenas para o tabagismo ativo e para o consumo excessivo de álcool. Em 2015, o Ministério da Saúde registrou 17.972 óbitos associados ao fumo passivo. Estudos comprovam que os efeitos imediatos da poluição ambiental pela fumaça do cigarro não são apenas de curto prazo, mas também está relacionada ao aumento do risco de câncer de pulmão e de infarto, além de prejudicar o sistema imunológico (Wong et al., 2007; Stampli e Anderson, 2009).

A fumaça de cigarro é considerada nociva devido aos 50 componentes conhecidamente carcinogênicos que a constituem (Oberg et al., 2011), sendo a nicotina, o monóxido de carbono e o cianeto de hidrogênio os mais comuns relacionados com um pior processo de reparo (Silverstein, 1992; Haverstoch \& Mandrachia, 1998) e outros componentes como a acroleína e o acetaldeído que têm mostrado in vitro um efeito prejudicial na proliferação e adesão de fibroblastos, células importantes para o processo de cicatrização (Cattaneo et al., 2000; Rota et al., 2001; Poggi et al., 2002). Alem disso diversos estudos in vivo e in vitro demonstraram que a nicotina e outras substâncias tóxicas encontradas na fumaça de cigarros (Jones \& Triplett, 1992; Ward \& Klesges, 2001; Nociti et al., 2002a; Nociti et al., 2002b; César-Neto et al., 2003; Henemyre et al., 2003;César-Neto et al., 2005a; César-Neto et al., 2005b; Kanis et al., 2005; César- Neto et al., 2006) podem inibir a revascularização (Daftari et al., 1994), tem um efeito negativo no reparo ósseo (Hollinger et al., 1999), promove inibição do reparo ósseo após regeneração óssea guiada (Saldanha et al., 2004) e inibe a expressão de muitas citocinas incluindo aquelas associadas com a neovascularização (Theiss et al., 2000; Henemyre et al., 2003; César-Neto et al., 2006) e diferenciação osteoblástica (Theiss 
et al., 2000; Zheng et al., 2008). Tendo em vista todas essas alterações no reparo ósseo quando da inalação da fumaça de cigarro e considerando que a extração dentária é um dos procedimentos mais frequentes na clinica odontológica, devido à destruição por lesões de cárie, tratamento ortodôntico, exfoliação fisiológica, traumatismos e pela perda óssea, a qual compromete a estabilidade e função do elemento dentário, utilizamos na presente pesquisa o LBP para tentar amenizar tais efeitos negativos relacionados à fumaça de cigarro.

Os efeitos bioestimulatórios da radiação laser de baixa potência (LBP) têm sido estudados por diversos autores que afirmam que a mesma acelera o processo de cicatrização de feridas (Prado et al.2000; Pinfildi et al., 2009), aumenta o fluxo sanguíneo (Prado et al., 2000, Kipshidze et al., 2001; Prado et al.,2006; Prado et al.,2009; Prado et al., 2010; das Neves et al., 2011) e promove a liberação e secreção do fator de crescimento vascular relacionado à angiogênese (Prado et al.2000), permitindo um suprimento mais adequado de oxigênio e nutrientes para atender às necessidades da fase proliferativa no processo de cicatrização (Kipshidze et al., 2001). Tem sido mostrado que o LBP tem efeitos positivos na reparação óssea após extração dentária (Fukuoka et al., 2011; Korany et al., 2012; Ribeiro, 2013; Park et al., 2015).

Dessa maneira, foi realizada neste estudo a avaliação dos principais mediadores moleculares envolvidos no processo de reparo ósseo após exodontia em ratos submetidos à inalação de fumaça de cigarro e à terapia com laser de baixa potência. A utilização de ratos como animais de estudo oferece a oportunidade de avaliar o processo de remodelação óssea intramembranosa em diversas condições patológicas, além de proporcionar menos interferências de fatores de confusão, que podem estar presentes em humanos. A escolha do rato, como modelo animal experimental da remodelação óssea também pode ser explicado pelo fato das respostas dos tecidos ósseos destes mamíferos às injúrias serem semelhantes às encontradas em humanos (Klausen, 1991). O modelo de remodelação óssea utilizado neste estudo, associado à extração dentária in vivo, foi previamente descrito na literatura (Takeda, 1988; Calixto, 2001; Korany et al., 2012; Ozkan et al., 2014; Park et al., 2015) e demonstrou ser um sistema efetivo para mostrar a remodelação óssea de alvéolos dentários, por isso foi utilizado para avaliar os efeitos da fumaça de cigarro e da radiação do laser de baixa potência sobre a remodelação e neoformação óssea. $O$ tempo de 3 semanas de exposição prévia à 
fumaça a que os animais foram submetidos, anterior à realização da extração dentária, foi definido com o objetivo de avaliar os efeitos crônicos da fumaça no metabolismo ósseo (Pinto et al., 2002; Santiago et al., 2017), tendo em vista que o turnover ósseo dos roedores varia em torno de 21 dias para ocorrer.

As informações genéticas são expressas pelas células eucarióticas baseadas no princípio central da biologia molecular. Este princípio consiste no fato de que uma sequência de nucleotídeos de uma região específica da molécula de DNA em um cromossomo é inicialmente copiada sob a forma de RNA durante o processo de transcrição. As cópias de RNA, chamadas de moléculas de RNAm, provenientes de segmentos de DNA, são utilizadas como moldes para a síntese proteica durante o processo de tradução. A transcrição do DNA em RNAm dos eucariotos é realizada pela enzima RNA polimerase II. Os RNAms processados dentro do núcleo são transportados para o citoplasma celular e, após maturação, são traduzidos em proteínas pelos ribossomos. A transcrição e a tradução são os meios pelos quais se estuda a expressão gênica das diferentes células (Alberts et al., 2008).

O padrão de expressão gênica celular pode ser alterado em resposta a mudanças em seu meio ambiente. Uma célula pode regular a expressão de cada um de seus genes de acordo com a sua necessidade, através do controle da produção de seus RNAs ou pela capacidade de alterar seus níveis proteicos (Alberts et al., 2010). Contudo, é necessário esclarecer que o RNAm de genes estimulados ou inibidos nem sempre correspondem ao mesmo perfil proteico. A expressão gênica pode ser regulada em diferentes etapas no caminho que vai do DNA ao RNA até a produção de proteínas. A expressão de diferentes genes e proteínas nas células pode ser modulada por uma complexidade de eventos existentes. Desta maneira, torna-se importante enfatizar que existem diversos mecanismos para regulação da expressão gênica, tais como (1) controle transcricional (controlando quando e como um determinado gene pode ser transcrito), (2) controle pós-transcricional, isto é, controle do processamento de RNA, transporte de RNA e controle da sua localização no citoplasma, (3) controle traducional, (4) controle da degradação do RNAm e (5) controle da atividade proteica (Alberts et al., 2008).

Desta maneira, os processos de regulação gênica e tradução proteica não necessariamente são o reflexo um do outro. No modelo utilizado no presente estudo, o padrão de formação ou reabsorção óssea observados histologicamente deve ser 
interpretado juntamente com os resultados obtidos em nível molecular. Isto porque a expressão gênica reflete o status da atividade celular, ao passo que os dados histológicos refletem a execução de uma cascata de eventos sinalizados pela atividade gênica e expressos no tecido ao longo do tempo.

Visto que existem diferentes mecanismos complexos que controlam a expressão gênica e celular, a seguir foram discutidos os resultados obtidos no presente estudo.

Num primeiro momento foi realizada análise comparativa dos Grupos Experimentais- Exp I (LBP), Exp II (FC) e Exp III (LBP + FC) em relação ao Grupo Controle $(C)$ avaliando a porcentagem de formação óssea- análise histométrica- e valores de expressão gênica. Em segunda análise, os valores de expressão gênica e a porcentagem de formação óssea do grupo Exp I foram comparados aos dos grupos Exp II e Exp III.

Aos 3 dias a análise histométrica da neoformação óssea na área do alvéolo foi significativamente maior no grupo experimental I (LBP) $(p<0,01)$ em relação ao Grupo Controle (C), sendo que nos grupos Exp II (FC) e III (LBP+FC) não houve diferença estatística neste período. Aos 7 dias no Grupo Exp I (LBP) o aumento foi significativo $(p<0,001)$ e no Exp II $(F C)$ a redução em relação ao controle também foi significativo $(p<0,01)$, sendo que no grupo Exp III $(L B P+F C)$ não houve diferença estatística neste período. Aos 14 dias houve aumento significativo entre o Grupo Controle e Exp I (LBP) $(p<0,01)$ e entre o Grupo Controle e Exp II (FC) houve uma redução significativa $(p<0,01)$, no grupo $\operatorname{Exp}$ III $(L B P+F C)$ não houve diferença estatística neste período. Podemos observar que o grupo exposto à $\mathrm{FC}$ teve o pior reparo ósseo, o que vai de encontro com os resultados de Giorgetti et al., 2012 que avaliaram a influencia da FC em ratos após extração dentária no período de 3,7 e 14 dias. Assim como no nosso estudo, no período de 3 dias não houve diferença estatisticamente significante entre $\circ$ grupo com $F C$ e $\circ$ grupo $C$, isso pode ter ocorrido devido ao fato de que no período de 3 dias ainda havia pequenas áreas de coágulo sanguíneo, numerosos macrófagos e presença de tecido conjuntivo sem diferenciação óssea, não havendo uma neoformação óssea ainda. Já no período de 7 dias a FC afetou negativamente $(p<0,05)$ a formação óssea em relação ao grupo $C$, assim como no nosso estudo. Neste período foi observado histologicamente, em nosso estudo, que o epitélio da mucosa gengival ainda não recobria totalmente a região do alvéolo, ao contrário do que foi observado no grupo controle, onde o 
epitélio recobria totalmente a região do alvéolo, isso pode ter interferido nos resultados, uma vez que havia contato do tecido conjuntivo ao meio externo. No grupo Exp II (FC) havia presença de discreto infiltrado inflamatório, o que neste período já não era mais observado no grupo $\mathrm{C}$, demonstrando o atraso na regeneração óssea. No período de 14 dias Giorgetti et al., 2012 não encontraram diferenças estatisticamente significativas $(p>0,05)$ do grupo com FC em relação ao grupo C, o que não vai de encontro com nossos resultados. Observamos neste período uma redução significativa $(p<0,01)$ de neoformação óssea no grupo exposto à $\mathrm{FC}$ quando comparado ao grupo $\mathrm{C}$. Essa diferença entre os resultados no período de 14 dias encontrados por Giorgetti e colaboradores e nossa pesquisa, pode ser devido ao numero de dias em que os animais receberam a FC, pois os referidos autores aplicaram a fumaça somente 3 dias antes da extração dentária, , o que seria compatível com efeito agudo dos agentes constituintes da fumaça de cigarro sobre o processo de reparo ósseo e em nosso estudo os animais receberam a FC 21 dias antes da extração dentária e durante todo o período após a extração até o dia da eutanásia, , o que caracteriza exposição crônica aos efeitos nocivos desses agentes sobre o processo de reparo ósseo. Acreditamos que no período de 14 dias, no trabalho de Giorgetti, a FC já não se encontrava mais influenciando a reparação do alvéolo.

Em contrapartida, a análise histométrica do grupo submetido à aplicação do LBP apresentou o melhor reparo do alvéolo dentário quando comparado ao grupo C e aos outros grupos experimentais, o que corrobora com outros estudos: Korany et al., 2012 mostraram que a aplicação do LBP acelerou a maturação do novo tecido ósseo e aumentou a quantidade de deposição óssea em alvéolos de ratos após exodontia. Sella et al., 2015 observaram que a aplicação de LBP, em fraturas femorais de ratos, aumentou o volume ósseo, a superfície dos osteoblastos e as taxas de aposição mineral, sugerindo que LBP aumentou a atividade em células ósseas. Hamad et al., 2016 encontraram que a aplicação do LBP, em alvéolos de coelho após exodontia, tornou a neoformação óssea mais rápida, além de aumentar a densidade e o volume do osso trabecular.

$\mathrm{Na}$ análise histométrica da neoformação óssea na área do alvéolo no grupo Exp III (LBP+FC) foi observado um aumento quando comparado ao grupo Exp II (FC), e uma diminuição quando comparado ao grupo $\mathrm{C}$, no entanto não houve diferença estatisticamente significante em nenhum dos períodos. Apesar do LBP ter 
melhorado o reparo ósseo, não foi suficiente para compensar os efeitos maléficos da fumaça de cigarro. Talvez isso possa ser explicado pelo fato de que o LBP foi aplicado somente nos 3 dias iniciais do experimento e a FC foi aplicada por todo o período experimental. Não há na literatura nenhum trabalho que avaliou os efeitos do LBP associado à exposição à FC na remodelação óssea em alvéolos de ratos após extração. Encontramos trabalhos como o de Peron et al., 2015 que avaliaram a eficácia da terapia celular com o uso de células estromais mesenquimal (MSCs) associada ao LBP, na doença pulmonar obstrutiva crônica induzida pela fumaça de cigarro. Moraes, 2010 analisou a influência do LBP sobre o processo de reparo de enxertos ósseos autógenos em bloco na mandíbula de ratos modificados sistemicamente pela nicotina. E das Neves et al., 2011 que estudaram o efeito do LBP sobre a viabilidade de retalho cutâneo em ratos submetidos aos efeitos deletérios da nicotina injetada. Os três observaram efeito positivo do laser, entretanto não há como compararmos nossos resultados com os pesquisadores citados, pois os mesmos avaliaram tecido, tipo de reparo e aplicação dos componentes do cigarro, diferentes dos avaliados por nós.

$\mathrm{Na}$ presente pesquisa o LBP melhorou o reparo ósseo, porem não conseguiu compensar os efeitos prejudiciais da FC. Isso pode ter ocorrido porque 0 laser foi aplicado somente por 3 dias, enquanto a fumaça de cigarro foi mantida por todo período experimental, e esta observação é importante de ser frisada.. Visto que a reparação óssea alveolar total em ratos ocorre aproximadamente aos 21 dias pósoperatório (Takeda, 1988; Garcia, 1992; Garcia et al., 1995b; Garcia et al., 1996, Limeira Junior, 2001), talvez se aplicássemos o laser por todo o período experimental, este estimularia as células e ativaria os genes a ponto de ser superior ao efeito inibitório da FC, portanto mais pesquisar são indispensáveis para se identificar quantos dias são necessários de aplicação da irradiação laser para acelerar ainda mais o reparo na presença da FC.

O receptor ativador do Fator Nuclear Kappa B (RANK), o ligante de RANK (RANKL) e a osteoprotegerina (OPG) fornecem a base celular e molecular para 0 cross-talk entre osteoblasto e osteoclasto, células cruciais no processo de remodelação óssea (Horowitz et al., 2001). O RANK, que pertence à superfamília do fator de necrose tumoral (TNF), está presente na superfície dos precursores de osteoclastos e é ativado pelo RANKL. Esta interação induz a diferenciação de monócitos em osteoclastos, assim iniciando o processo de reabsorção. O sistema 
RANK/RANKL/OPG controlam o processo de remodelação e fazem parte do metabolismo ósseo. O RANKL é um agonista que regula aspectos importantes dos osteoclastos como diferenciação, fusão, sobrevivência, ativação e apoptose. Uma vez que ativação de RANK por RANKL inicia o processo de reabsorção óssea, este mediador solúvel pode ser considerado um marcador de reabsorção óssea. Por outro lado, a OPG, também membro da superfamília do TNF, é um receptor solúvel secretado, que é um antagonista do RANKL, uma vez que interrompe esta ativação pela ligação direta ao RANKL evitando o processo de reabsorção óssea, isto é, a OPG regula negativamente o processo de osteoclastogênese (Horowitz et al., 2001).

A expressão gênica da tríade Rank/Rankl/Opg, foi significativamente menor para os grupos Exp II (FC) e Exp III (LBP+FC) em todos os períodos avaliados quando comparados ao grupo $\mathrm{C}$, exceto para a expressão gênica de Opg no grupo Exp III (LBP+FC) nos períodos de 7 e 14 dias que foi menor porém sem significância estatística, enquanto para o grupo Exp I (LBP) houve um aumento significativo da expressão de Rank apenas no período de 3 dias, um aumento significativo da expressão de Rankl apenas no período de 7 dias e um aumento significativo na expressão de Opg em todos os períodos experimentais.

Observa-se por meio destes dados que o estímulo gênico para reabsorção óssea foi notado apenas nos grupos Exp II (FC) e Exp III (LBP+FC) em todos os períodos e no grupo Exp I (LBP) nos períodos mais iniciais (3 e 7 dias) do processo de reparo, sendo este estimulo prejudicado na presença da FC, enquanto que o estímulo gênico para evitar reabsorção óssea ocorre durante todo o período de reparo e é mais expressivo no grupo de animais que recebeu a aplicação do LBP, fatos também comprovados com os cortes histológicos, onde observamos um aumento no grau de deposição óssea. A relação gênica de Rankl e Opg (razão Rankl/Opg) tem o intuito de mostrar se o metabolismo ósseo estava mais direcionado para a formação ou reabsorção óssea. Os dados do presente estudo demonstraram um aumento na razão Rankl/Opg nos períodos iniciais de reparo para o grupo Exp II (FC) quando comparado ao grupo C, o que pode sinalizar o predomínio de atividade osteoclástica nesta fase precoce de reparo e inflamação.

Lee e colaboradores em 2009 avaliaram a expressão gênica de mediadores relacionados à reabsorção óssea em células do ligamento periodontal humano tratadas com nicotina e demonstraram redução na expressão de Opg e aumento na expressão de Rankl, o que sugere estímulo para o processo de reabsorção óssea no 
padrão de atividade destas células. Li-Zheng e colaboradores em 2013 coletaram e cultivaram em meio de cultura células de ligamento periodontal de 3 pacientes

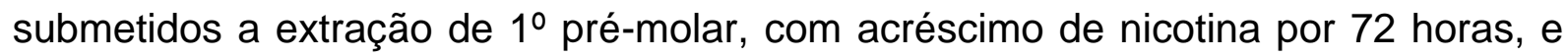
constataram por meio da metodologia de PCR real-time maiores níveis de expressão gênica para Rankl após exposição destas células à nicotina, enquanto que houve inibição da expressão de Opg, resultando numa razão Rankl/Opg direcionada para a reabsorção óssea.

Esses achados da literatura concordam em parte com o presente estudo, pois houve efeito inibitório na expressão de Opg no grupo de animais submetido à FC. Porém, nestes mesmos animais, não foi observado aumento na expressão de Rankl em consequência da exposição à fumaça de cigarro. A comparação do grupo $\mathrm{C}$ com o grupo Exp II (FC) e Exp III ( $\mathrm{LBP}+\mathrm{FC})$ demonstrou que a exposição à fumaça de cigarro inibiu a expressão de Rankl. Considerando-se que o presente estudo foi realizado in vivo, é provável que a modulação da atividade desses genes esteja submetida a um complexo sistema regulador, enquanto que avaliações in vitro caracterizam respostas de células isoladas, que não estão sob a influência de outros fatores regulatórios inerentes a um organismo em funcionamento. Além disso, a expressão gênica celular nesses estudos in vitro foi avaliada com relação ao efeito da nicotina, que é o componente majoritário da fumaça de cigarro, mas não exclusivo. No presente trabalho, os animais foram expostos à fumaça de cigarro e todas as substâncias nocivas que a constituem, o que poderia justificar a diferença de resposta na expressão gênica observada.

Shin e colaboradores em 2016 avaliaram a expressão gênica de Rankl/Opg em osteoblastos tratados com bisfosfonato (alendronato) e com LBP. Observam que o LBP aumentou as expressões de RANKL em relação às células tratadas com alendronato, resultando em efeitos positivos na osteoclastogênese. Sendo que as expressões de Opg foram menores quando comparadas ao grupo controle, porém não foram estatisticamente significantes. Saito e colaboradores em 2011 avaliaram o efeito do LBP no processo de cicatrização de dentes reimplantados de ratos após diferentes períodos extra-orais quanto á expressão gênica de Rank/ Rankl/ Opg. Mostrando que a expressão dos referidos genes não apresentaram diferença estatisticamente significante quando comparado ao grupo controle. Esses resultados podem ser decorrentes dos padrões do laser escolhido. Talvez a quantidade de 
aplicações do laser, ou seus parâmetros utilizados no estudo não foram suficientes para afetar a expressão gênica.

A expressão gênica de Bmp2, Bsp e Occ foi significativamente maior para o grupo Exp I (LBP) comparado ao grupo C, nos tempos de 3, 7 e 14 dias. No grupo Exp II (FC), quando comparado ao grupo $\mathrm{C}$, houve uma diminuição estatisticamente significante da expressão gênica de Bmp2 e Occ em todos os períodos experimentais e uma diminuição da expressão gênica de Bsp estatisticamente significante somente nos períodos de 3 e 14 dias, quando comparado ao grupo C. Quando analisamos o grupo Exp III (LBP+FC) a expressão gênica de Bmp2 e Bsp não foram estatisticamente significantes quando comparado ao grupo $\mathrm{C}$ em nenhum dos períodos analisados, já a expressão gênica de Occ apresentou uma diminuição estatisticamente significante somente no período de 3 dias, quando comparado ao grupo C. O que demonstra que o LBP interferiu positivamente na expressão destes genes e a FC negativamente.

A Bmp2 é uma proteína importante no processo de desenvolvimento ósseo e cartilaginoso. Ela está envolvida com a diferenciação de células mesenquimais em osteoblastos e condroblastos, na via de sinalização do TGF- $\beta$ (fator de transformação do crescimento) e na interação de receptores de citocina (Chen et al., 2004). Os resultados do presente estudo demonstraram um aumento significativo na expressão gênica de Bmp2 para o grupo Exp I (LBP) nos períodos de 3, 7 e 14 dias quando comparado ao grupo C. Esta sinalização expressiva parece estar relacionada com o processo de maturação óssea. Nossos resultados vão de encontro com os resultados obtidos por Tim e colaboradores (2015) que avaliaram os efeitos do LBP na expressão gênica de Bmp em defeito ósseo na tíbia de ratos e observaram que o LBP produziu um aumento significativo na expressão de Bmp que poderia estimular a proliferação e diferenciação de osteoblastos, o que pode estar relacionado à melhoria da deposição de osso recém formado no local da lesão.

O trabalho de Giorgetti et al., 2010 avaliou a expressão gênica de Bmp2 no reparo ósseo alveolar de ratos submetidos à fumaça de cigarro. A análise intergrupos demonstrou que FC reduziu significativamente os níveis de mRNA de Bmp2 no período de 10 dias (período tardio), o que concorda em partes com nossos resultados, pois encontramos uma redução significativa dos níveis de Bmp2 em todos os períodos experimentais nos animais expostos à FC. Talvez essa diferença 
seja devido ao período curto de exposição à FC (3 dias) realizada pelo trabalho citado.

A BSP é uma proteína não colágena envolvida no processo de formação óssea e secretada por osteoblastos. A expressão do RNAm de lbsp foi avaliada por Stein et al., 2005 que investigaram o efeito da irradiação laser de baixa potência na proliferação e diferenciação de uma linha celular de osteoblasto humano e observaram um aumento duas vezes maior na expressão de BSP nas células irradiadas em comparação com os osteoblastos não irradiados. Estes resultados concordam com o da presente pesquisa, onde pode-se observar que o grupo Exp I (LBP) apresentou uma maior expressão gênica de BSP em todos os períodos experimentais quando comparado ao grupo C, o que demonstra uma sinalização para o processo de formação óssea não só no período inicial, como também intermediário e tardio pós extração.

Quando avaliamos a expressão gênica de BSP no grupo Exp II (FC) observamos uma diminuição expressiva nos períodos de 3 e 14 dias, quando comparado ao grupo C. Nossos resultados corroboram em partes com os resultados de Yamano et al., 2010 que avaliaram os efeitos da administração de nicotina sobre a expressão gênica de BSP na osseointegração de implantes de titânio em fêmures de ratos. Ao contrario do nosso estudo os referidos autores observaram níveis de expressão de mRNA de BSP maiores no grupo que recebeu nicotina quando comparados ao grupo C, no período inicial do trabalho ( 2 semanas). No presente trabalho foi observado uma diminuição destes níveis no período inicial (3 dias). Já no período tardio de 4 semanas do trabalho de Yamano e colaboradores a expressão gênica de BSP no grupo com nicotina significativamente diminuiu em comparação com o grupo controle, igualmente em nosso trabalho onde observamos uma diminuição da expressão de BSP no período de 14 dias (período tardio para nosso tipo de reparação óssea). A expressão do gene relacionado à matriz óssea pareceu ser regulada negativamente em um animal influenciado pela nicotina no estágio tardio (Yamano et al., 2010).

A Occ é mais uma proteína não colágena da matriz de tecidos mineralizados, sintetizada pelos osteoblastos, odontoblastos e condrócitos hipertrofiados. O gene Occ é considerado um marcador da atividade e função dos osteoblastos, um marcador tardio de osteoblastos diferenciados ou maduros (Tanaka et al., 2007), 
marcador de formação óssea (Motyl et al., 2009), além de participar no processo de reabsorção óssea e mineralização (Roach, 1994).

No presente trabalho foi observado um estímulo gênico de Occ no período de 3, 7 e 14 dias para o grupo Exp I (LBP) quando comparado ao grupo C. E mais uma vez a fumaça de cigarro parece prejudicar o processo de remodelação óssea, considerando-se que houve uma diminuição nos valores de expressão gênica para Occ no grupo Exp II (FC) e Exp III (LBP+FC) quando comparados ao grupo C, em todos os períodos experimentais com exceção dos períodos de 7 e 14 dias no grupo Exp III (LBP+FC) que não foram estatisticamente significantes. Os achados de Ramp e colaboradores (1988) confirmam este efeito prejudicial da fumaça na expressão deste gene em um estudo analisando o efeito da nicotina sobre as culturas de células do tipo osteoblasto. Os resultados mostraram que a nicotina inibiu a atividade da fosfatase alcalina e a síntese de colágeno num padrão dosedependente, o que denota alteração no padrão normocelular destas células.

O resultado positivo que o LBP gerou na expressão do referido gene na presente pesquisa também é encontrado na pesquisa de Park et al., 2015 que avaliaram o efeito de diferentes tempos (3 e 7 dias) de aplicação de LBP em alvéolos de ratos após exodontia na expressão de Occ, observando um aumento das expressões de Occ no grupo irradiado com o LBP em todos os períodos experimentais, quando comparado ao grupo controle. Sendo este aumento duas vezes maior no grupo irradiado por 7 dias quando comparado ao grupo irradiado por 3 dias. Analisando estes resultados, talvez a expressão de Occ em nosso estudo seria maior ainda se tivéssemos aplicado o laser por mais dias, como feito por Park e colaboradores. Em conclusão, o LBP teve efeitos positivos na cicatrização óssea dos alvéolos dentários de ratos.

A Onc está envolvida na regulação do turnover da matriz, na migração e proliferação celular (Jandeleit-Dahm et al., 2000; Kos e Wilding, 2010), e devido a estas propriedades, esta proteína tem participação no processo de reparo, angiogênese e inflamação (Brekklen e Sage, 2001). Esses dados justificam o aumento na expressão gênica de Onc observado neste estudo para o grupo Exp I (LBP), nos tempos iniciais (3 e 7 dias), sendo que no período de 14 dias não houve diferença estatisticamente significante. Nossos resultados corroboram com os de Sella e colaboradores (2015), que avaliaram a influência do LBP na expressão dos genes Onc e Opn no reparo de fraturas femorais de ratos, nos períodos de 8, 13 e 
18 e observaram uma maior expressão de osteonectina (Onc) nos ratos do grupo com LBP quando comparados com os ratos do grupo controle no período de 13 dias e nenhuma diferença significativa foi observada entre os dois grupos no período de 18 dias. Estes resultados comprovam que a modulação na expressão deste gene é importante e ocorre nas fases iniciais e intermediária de reparo. Sella et al.,2015 mostraram também que a osteopontina (Opn) apresentou o comportamento esperado, ou seja, um aumento nos dias 8 e 18 e uma diminuição no dia 13 em ambos os grupos, sendo a diferença entre o grupo LBP e o grupo controle significativa apenas no dia $8(p=0,033)$. Em nosso trabalho este resultado não foi encontrado. O grupo Exp I (LBP) apresentou um aumento na expressão deste gene, quando comparado ao grupo $\mathrm{C}$, porém em nenhum dos períodos analisados $\mathrm{O}$ aumento foi estatisticamente significante.

Diversos estudos tem demonstrado que a Opn parece ter um papel importante na regulação da resposta celular em diferentes condições de estresse químico, físico e mecânico (Denhart e Noda, 1998; Terai et al., 1999; Nomura et al., 2000). Sabe-se que o estresse mecânico deforma a matriz óssea e gera um estímulo que leva ao processo de remodelação óssea. A Opn que está presente na matriz óssea é requerida para participar neste processo, uma vez que é necessária para a função (Terai et al., 1999; Fujihara et al., 2006; Chung et al., 2008) e aumento da sobrevivência dos osteoclastos (Tanabe et al., 2011), além de também reduzir a diferenciação, proliferação e quimiotaxia de osteoblastos e osteoclastos (Terai et al., 1999, Ishima et al., 2001; Ishima et al., 2007). No presente estudo foi observado uma diminuição na expressão gênica de Opn nos grupos Exp II (FC) e Exp III $(\mathrm{LBP}+\mathrm{FC})$, em todos os tempos avaliados, mostrando que a fumaça de cigarro parece influenciar negativamente a atividade deste mediador em situação de reparo ósseo após exodontia.

A exposição à fumaça de cigarro parece prejudicar o processo de reparo quando se analisa a expressão gênica de Onc (Osteonectina), uma vez que os valores dessa expressão nos grupos Exp II (FC) e Exp III (LBP+FC) foram menores quando comparados ao grupo controle no período de 3 e 7 dias, sendo 14 dias sem significância estatística. Nossos dados foram opostos aos resultados de Marinucci et al., 2014 que examinaram os efeitos da exposição a uma única ou múltiplas concentrações sub-tóxicas de nicotina em osteoblastos humanos e observaram aumento na expressão de Onc em osteoblastos tratados com nicotina quando 
comparados ás células não tratadas. No trabalho de Marinucci e colaboradores foram avaliados apenas os efeitos da nicotina em osteoblastos, ou seja, um tipo de célula in vitro que oferece respostas isoladas. Na presente pesquisa foi avaliada a influência da FC, que além da nicotina inclui outros componentes tóxicos, em um animal vivo caracterizando a complexidade de um organismo em funcionamento, o que poderia justificar a diferença de resposta na expressão gênica observada.

Considerando a metodologia empregada e os resultados obtidos neste estudo, a aplicação do laser de baixa potência favoreceu o processo de remodelação óssea, e estimulou a expressão gênica dos mediadores ósseos avaliados (Bmp-2, Bsp, Opn, Onc, Occ, Rank, Rankl e Opg). E a exposição à fumaça de cigarro causou prejuízo consistente na expressão gênica de todos os mediadores ósseos avaliados neste estudo, além do reparo mais lento e desorganizados observados histologicamente. No entanto, futuras investigações são necessárias para elucidar os mecanismos moleculares pelos quais o laser e a fumaça de cigarro atuam no organismo, bem como as vias de sinalização envolvidas no processo de remodelação óssea sob tais circunstâncias. 

6. Conclusão 



\section{CONCLUSÃO}

A partir do presente estudo pode-se concluir que:

1. A ação do laser de baixa potência, favoreceu o processo de remodelação óssea após a extração dentária em ratos, principalmente nos períodos de 3 e 7 dias, sendo que no período final do experimento não houve diferença no reparo ósseo entre o grupo irradiado e o não irradiado. Quanto aos genes envolvidos no processo de remodelação óssea (Bmp-2, Bsp, Opn, Onc, Occ, Rank, Rankl e Opg) apresentaram estimulo na expressão gênica durante os períodos experimentais, após a aplicação do laser de baixa potência.

2. A fumaça de cigarro interferiu na formação óssea em todos os períodos experimentais, atrasando este processo. Os genes envolvidos no processo de remodelação óssea (Bmp-2, Bsp, Opn, Onc, Occ, Rank, Rankl e Opg) sofreram influência negativa; reduzindo seus valores durante o todo o período experimental.

3. O grupo submetido à fumaça de cigarro foi o que demonstrou o maior atraso na remodelação óssea e na expressão gênica dos genes avaliados. Quando este grupo recebeu a aplicação do laser de baixa potência houve uma melhora nas respostas histológicas e gênicas, porém ainda assim foram menores que o grupo que recebeu apenas o laser de baixa potência. 

Referências 



\section{REFERÊNCIAS}

Alberts B, Johnson A, Lewis J, Raff M, Roberts K, Walter P. Molecular biology of the cell. 5a ed. Nova York: Garland Science, 2008.

Amler $\mathrm{MH}$. The time sequence of tissue regeneration in human extraction wounds. Oral Surg Oral Med Oral Pathol 1969 Mar;27(3):309-18.

Boyle WJ, Simonet WS, Lacey DL. Osteoclast differentiation and activation. Nature 15: 33742, 2003.

Brekken RA, Sage EH. SPARC, a matricellular protein: at the crossroads of cell-matrix communication. Matrix Biol. 2001; 19:816-27.

Brugnera JA, Zanin F. Tratamento da hipersensibilidade dentinária. In: Lasers na Odontologia Moderna, Brugnera J.A. Pinheiro ALB.-São Paulo: Pancast. 1998, cap.19, p.297-306.

Bustin SA. Absolute quantification of mRNA using real-time reverse transcription polymerase chain reaction assays. J Mol Endocrinol, v. 25, n. 2, p. 169-93, Oct 2000. ISSN 0952-5041

Calixto RFE. Implante de um Foliculado de Resina Derivado do Óleo de Mamona (Ricinus comunnis) em Alveolo de Rato Imediatamente após a Extração Dental. Avaliações Histológicas e Histométricas da Biocompatibilidade e da Cronologia do Reparo Ósseo. 2001. 72 p. Dissertação (Mestrado em Odontologia-Área).

Carvalho ACP, Okamoto T. Cirurgia bucal: fundamentos experimentais aplicados a clínica. São Paulo: Panamericana; 1987.

Cattaneo V, Celta G, Rota C, Vezzoni F, Gallanti A. Volatile components of cigarette smoke: effect of acrolein and acetaldehyde on human gingival fibroblasts in vitro. J Periodontol. 2000; 71(3):425-32.

César-Neto JB, Benatti BB, Manzi FR, Sallum EA, Sallum AW, Nociti FH. The influence of cigarette smoke inhalation on bone density. A radiographic study in rats. Pesqui Odontol Bras. 2005; 19(1):47-51.

César-Neto JB, Benatti BB, Neto FH, Sallum AW, Sallum EA, Nociti FH. Smoking cessation may present a positive impact on mandibular bone quality and periodontitis-related bone loss: a study in rats. J Periodontol. 2005; 76(4):520-525.

César-Neto JB, Benatti BB, Sallum EA, Casati, Nociti FH Jr. The influence of cigarette smoke inhalation and its cessation on the tooth-supporting alveolar bone: a histometric study in rats. J Periodontal Res. 2006; 41(2):118-123.

César-Neto JB, Duarte PM, Sallum EA, Barbieri D, Moreno H Jr, Nociti FH Jr. A comparative study on the effect of nicotine administration and cigarette smoke inhalation on bone healing around titanium implants. J Periodontol. 2003; 74(10):1454-1459.

Chen D, Zhao M, Mundy GR. Bone morphogenetic proteins. Growth Factors. 2004; 22(4):233-41. 
Chomette G, Auriol M, Zeitoun R, Mousques T. [Effect of the soft laser on gingival connective tissue. I--Effect on fibroblasts. Histoenzymology and electron microscopy study]. J Biol Buccale 1987 Mar; 15(1):45-9.

Chomette G, Auriol M, Zeitoun R, Mousques T. [Effect of the soft laser on gingival connective tissue. Il--Effect on wound healing. Optical microscopy, histoenzymology and electron microscopy studies]. J Biol Buccale 1987 Mar;15(1):51-7.

Chung JW, Kim MS, Piao ZH, Jeong M, Yoon SR, Shin N, Kim SY, Hwang ES, Yang Y, Lee $\mathrm{SH}$, Kim YS, Choi I. Osteopontin promotes the development of natural killer cells from hematopoietic stem cells. Stem cells. 2008; 26:2114-23.

Colls J. La terapia laser actual. Barcelona: Centro de Documentación Laser-Medtec, 1984.

Daftari TK, Whitesides TE Jr, Heller JG, et al.; Nicotine on the revascularization of bone grafts. Spine 1994: 19:904.

das Neves LM1, Marcolino AM, Prado RP, Ribeiro Tde S, Pinfildi CE, Thomazini JA. Lowlevel laser therapy on the viability of skin flap in rats subjected to deleterious effect of nicotine. Photomed Laser Surg. 2011 Aug;29(8):581-7.

Denhardt DT, Noda M. Osteopontin expression and function: role in bone remodeling. $J$ Cell Biochem. 1998; (30-31):92-102.

Euler H. Die Heilung von extractions wounden. Detsch. Manat. Ank. 1923; v. 41, pp. 685689.

Freitas AC, Pinheiro AL, Miranda P, Thiers FA, Vieira AL. Assessment of anti-inflammatory effect of 830nm laser light using C-reactive protein levels. Braz Dent J 2001;12(3):187-90.

Fujihara S, Yokozeki M, Oba Y, Higashibata Y, Nomura S, Moriyama K. Function and regulation of osteopontin in response to mechanical stress. J Bone Mineral Res. 2006; $21: 956-64$.

Fukuoka H, Daigo $\mathrm{Y}$, Enoki N, Taniguchi $\mathrm{K}$, Sato $\mathrm{H}$. Influence of carbon dioxide laser irradiation on the healing process of extraction sockets. Acta Odontol Scand. 2011 Jan;69(1):33-40.

Garcia VG, Carvalho PS, Oliveira JA. Ação da radiação laser na reparação de feridas de extração dental infectadas: Estudo Histológico em Ratos. Rev. RGO.1995b; v. 4, n. 43, p. 191-194.

Garcia VG, Okamoto T, kina JR, Fonseca RG, Theodoro LH. Reparação de feridas de extração dental submetidas ao tratamento com raio laser: estudo histológico em ratos. Rev. Fac. Odont. Lins, 1996; vol.9-no1, pags.32-42 jan/jun.

Garcia VG. Comportamento de feridas cutâneas submetidas à ação do Raio Laser. Estudo clinico, biométrico e histológico em ratos. 1992. Tese/Livre-Docência. Faculdade de Odontologia, UNESP, Araçatuba-SP. healing in the hand. Hand 1977 Jun;9(2):97-101.

Giorgetti AP1, César Neto JB, Casati MZ, Sallum EA, Nociti Júnior FH. Cigarette smoke inhalation influences bone healing of post-extraction tooth socket: a histometric study in rats. Braz Dent J. 2012;23(3):228-34.

Giorgetti AP, César Neto JB, Ruiz KG, Casati MZ, Sallum EA, Nociti FH Jr. Cigarette smoke inhalation modulates gene expression in sites of bone healing: a study in rats. Oral Surg Oral Med Oral Pathol Oral Radiol Endod. 2010 Oct;110(4):447-52. 
Hamad SA, Naif JS, Abdullah MA. Effect of Diode Laser on Healing of Tooth Extraction Socket: An Experimental Study in Rabbits. J Maxillofac Oral Surg. 2016 Sep;15(3):308-314. Epub 2015 Sep 25.

Haverstoch BD, Mandracchia VJ. Cigarrete smoking and bone healing: implications in foot and ankle surgery. J Foot Ankle Surg. 1998; 37(1):69-74.

Henemyre CL, Scales DK, Hokett SD, Cuenin MF, Peacock ME, Parker MH, Brewer PD, Chuang $\mathrm{AH}$. Nicotine stimulates osteoclast resorption in a porcine marrow cell model. J Periodontol. 2003; 74(10):1440-6.

Hollinger JO, Schmitt JM, Hwang K, et al.; Impact of nicotine on bone healing. J Biomed Mater Res 1999:45:294.

Horowitz MC, Xi Y, Wilson K, Kacena MA. Control of osteoclastogenesis and bone resorption by members of the TNF family of receptors and ligands. Cytokine Growth Factor Rev. 2001; 12:9-18.

Ishijima M, Rittling SR, Yamashita T, Tsuji K, Kurosawa H, Nifuji A, et al. Enhancement of osteoclastic bone resorption and suppression of osteoblastic bone formation in response to reduced mechanical stress do not occur in the absence of osteopontin. J Exp Med. 2001; 193:399-404.

Ishijima M, Tsuji K, Rittling SR, Yamashita T, Kurosawa H, Denhardt DT, et al. Osteopontin is required for mechanical stress-dependent signals to bone marrow cells. J Endocrinol. 2007; 193:235-43.

Jandeleit-Dahm K, Rumble J, Cox AJ, Kelly DJ, Dziadek M, Cooper ME, Gilbert RE. SPARC gene expression is increased in diabetes-related mesenteric vascular hypertrophy. Microvasc Res. 2000; 59(1):61-71.

Jones JK, Triplett RG. The relationship of cigarette smoking to impaired intraoral wound healing: A review of evidence and implications for patient care. J Oral Maxillofac Surg. 1992; 50(3):237-40

Kana JS, Hutschenreiter G, Haina D, Waidelich W. Effect of low-power density laser radiation on healing of open skin wounds in rats. Arch. Surg., Chicago. Mar.1981; v. 116, n. 3, p. 293-296.

Kanis JA, Johnell O, Oden A, Johansson H, De Laet C, Eisman JA, Fujiwara S, Kroger $H$, McCloskey EV, Mellstrom D, Melton LJ, Pols H, Reeve J, Silman A, Tenenhouse A. Smoking and fracture risk: a meta-analysis. Osteoporos Int. 2005; 16(2):155-62.

Kawasaki K, Shimizu N. Effects of low-energy laser irradiation on bone remodeling during experimental tooth movement in rats. Lasers Surg Med 2000; 26(3):282-91.

Khadra M, Kasem N, Haanaes HR, Ellingsen JE, Lyngstadaas SP. Enhancement of bone formation in rat calvarial bone defects using low-level laser therapy. Oral Surg Oral Med Oral Pathol Oral RadiolEndod 2004 Jun; 97(6): 693-700.

Khadra M, Ronold HJ, Lyngstadaas SP, Ellingsen JE, Haanaes HR. Low-level laser therapy stimulates bone-implant interaction: an experimental study in rabbits. Clin Oral Implants Res 2004 Jun;15(3):325-32.

Kipshidze, N., Nikolaychik, V., Keelan, M.H., et al. (2001). Low-power helium-neon laser irradiation enhances production of vascular endothelial growth factor and promotes growth of endothelial cells in vitro. Lasers Surg. Med. 28, 355-364. 
Klausen B. Microbiological and immunological aspects of experimental periodontal disease in rats: a review article. J Periodontol 62, 1991; 59-73.

Korany NS1, Mehanni SS, Hakam HM, El-Maghraby EM. Evaluation of socket healing in irradiated rats after diode laser exposure (histological and morphometric studies). Arch Oral Biol. 2012 Jul;57(7):884-91.

Kos K, Wilding JP. SPARC: a key player in the pathologies associated with obesity and diabetes. Nat Rev Endocrinol. 2010; 6:225-35.

Le Mesurier SM, Stewart BW, Lykke AW. Injury to type-2 pneumocytes in rats exposed to cigarette smoke. Environ Res. 1981 Feb;24(1):207-17.

Lee HJ, Pi SH, Kim Y, Kim HS, Kim SJ, Kim YS, Lee SK, Kim EC. Effects of nicotine on antioxidant defense enzymes and RANKL expression in human periodontal ligament cells. $J$ Periodontol. 2009; 80(8):1281-8.

Limeira Júnior FA. Avaliação do processo de reparo ósseo com o uso de osso anorgânico e membrana reabsorvível após irradiação com laser diodo 830nm. 2001. Dissertação (Mestrado em Odontologia). Faculdade de Odontologia da Universidade Federal da Bahia. Salvador-Bahia.

Liu X, Lyon R, Meier HT, Thometz J, Haworth ST. Effect of lower-level laser therapy on rabbit tibial fracture. Photomed Laser Surg 2007 Dec; 25(6):487-94.

Livak, J. K.; Schmittgen, T. D. Analysis of relative gene expression data using real time quantitative PCR and the $22^{-\Delta \Delta \mathrm{Ct}}$ method. Methods - Applied Biosystems: Elsevier Science. 25: 402-408 p. 2001.

Li-Zheng W, Duo-Mo D, Ying-Feng L, Xin G, Zhi-Fei Z, Xiao-Jing W. Nicotine favors osteoclastogenesis in human periodontal ligament cells co-cultured with CD4+T cells by upregulating IL-1ß. Int J Molec Med. 2013; 31:938-42.

Marinucci L, Bodo M, Balloni S, Locci P, Baroni T. Sub-toxic nicotine concentrations affect extracellular matrix and growth factor signaling gene expressions in human osteoblasts. $J$ Cell Physiol. 2014; 229(12):2038-48

Meechan JG, Macgregor ID, Rogers SN, Hobson RS, Bate JP, Dennison M. The effect of smoking on immediate post-extraction socket filling with blood and on the incidence of painful socket. Br J Oral Maxillofac Surg 1988 Oct;26(5):402-9.

Messora MR et al. Bone healing in critical-size defects treated with platelet-rich plasma: a histologic and histometric study in rat calvaria. J Periodontal Res. 2008;43:217-223.

Mester E, Nagylucskay S, Tisza S, Mester A. Stimulation of wound healing by means of laser rays. Part III--Investigation of the effect on immune competent cells. Acta Chir Acad Sci Hung 1978;19(2):163-70.

Ministério da Saúde. Secretaria de Assistência à Saúde. Instituto Nacional de Câncer INCA. Estimativas da Incidência e Mortalidade por Câncer. Rio de Janeiro: INCA, 2002.

Moraes, RC. Influência do Laser em Baixa Intensidade no Processo de Reparo de Enxerto Ósseo Autógeno Implantado em Bloco na Mandíbula de Ratos Modificados Sistemicamente com Nicotina. 2010. 124p. Dissertação de Mestrado. Faculdade de Odontologia da Universidade Estadual Paulista "Júlio de Mesquita Filho" 
Mosely LH, Finseth F. Cigarette smoking: impairment of digital blood flow and wound healing in the hand. Hand. 1977 Jun;9(2):97-101.

Motyl KJ, Botolin S, IrwinR, et al. Bone inflammation and altered gene expression. With type I diabetes early onset. J Cell Physiol. 2009; 218:575-83.

Nadler JL, Velasco JS, Horton R. Cigarette smoking inhibits prostacyclin formation. Lancet 1983;4:1248-1250.

Nakagawa N, Kinosaki M, Yamaguchi K, Shima N, Yasuda H, Yano K, Morinaga T, Higashio K. RANK is the essential signaling receptor for osteoclast differentiation factor in osteoclastogenesis. BiochemBiophys Res Commun 1998 Dec 18; 253(2): 395-400.

Nicola RA, Jorgetti Y, Rigau J, Pacheco MT, dos Reis LM, Zangaro RA. Effect of low-power GaAIAs laser $(660 \mathrm{~nm})$ on bone structure and cell activity: an experimental animal study. Lasers Med Sci 2003;18:89-94.

Nicolau, R.A. Efeito do Laser de Baixa Potência (As-Ga-Al) em tecido ósseo de rato submetido à lesão, analisado por histomorfometria óssea. Universidade do Vale do Paraíba. 2001. 100 p. Dissertação (Mestrado EM Engenharia Biomédica)- Universidade do Vale do Paraíba - São José dos Campos, SP. Orientadores: Prof. Dr. Renato Amaro Zângaro

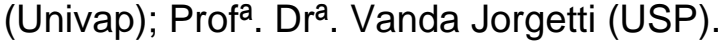

Nociti FH Jr, Cesar Neto JB, Carvalho MD, Sallum EA. Bone density around titanium implants may be influenced by intermittent cigarette smoke inhalation: a histometric study in rats. Int J Oral Maxillofac Implants. 2002; 17(3):347-52.

Nociti Junior FH, Cesar Neto JB, Carvalho MD, Sallum EA, Sallum AW. Intermittent cigarette smoke inhalation may affect bone volume around titanium implants in rats. J Periodontol. 2002; 73(9):982-987.

Nolan J, Jenkins RA, Kurihara K, et al. The acute effects of cigarette smoke exposure on experimental skin flaps. Plast Reconstr Surg 1985;75:544-551.

Nomura S, Takano-Yamamoto T. Molecular events caused by mechanical stress in bone. Matrix Biol. 2000; 19:91-6.

Öberg M, Jaakkola MS, Woodward A, Peruga A, Prüss-ustün A. Worldwide burden of disease from exposure to second-hand smoke: A retrospective analysis of data from 192 countries. Lancet. 2011; 377(9760):139-46.

Okamoto T, de Russo MC. Wound healing following tooth extraction. Histochemical study in rats. Rev Fac Odontol Aracatuba 1973;2(2):153-69.

Okamoto T, Fialho ACV. Estudo histologico comparativo entre dois métodos de obtencao de cortes de alveolos de ratos. Rev Odont UNESP 1990;19:63-74.

Ozkan A, Bayar GR, Altug HA, Sencimen M, Dogan N, Gunaydin Y, Ergodan E. The effect of cigarette smoking on the healing of extraction sockets: an immunohistochemical study. J Craniofac Surg. 2014 Jul;25(4):e397-402.

Park JB1, Ahn SJ, Kang YG, Kim EC, Heo JS, Kang KL. Effects of increased low-level diode laser irradiation time on extraction socket healing in rats. Lasers Med Sci. 2015 Feb;30(2):719-26.

Peron JP, de Brito AA, Pelatti M, Brandão WN, Vitoretti LB, Greiffo FR, da Silveira EC, 
Oliveira-Junior MC, Maluf M, Evangelista L, Halpern S, Nisenbaum MG, Perin P, Czeresnia CE, Câmara NO, Aimbire F, de Paula Vieira R, Zatz M, de Oliveira AP. Correction: Human Tubal-Derived Mesenchymal Stromal Cells Associated with Low Level Laser Therapy Significantly Reduces Cigarette Smoke-Induced COPD in C57BL/6 mice. PLoS One. 2015 Sep 25;10(9):e0139294.

Pinfildi, C.E., Liebano, R.E., Hochman, B.S., et al. (2009). Effect of low-level laser therapy on mast cells in viability of the transverse rectus abdominis musculocutaneous flap. Photomed. Laser Surg. 27, 337-343.]

Pinheiro ALB. Evolução Histórica e Classificação dos Lasers. In: Brugnera Júnior A, Pinheiro ALB. Lasers na Odontologia Moderna, São Paulo: Pancast, 1998 p.19-26.

Pinto JR, Bosco AF, Okamoto T, Guerra JD, Piza IG. Effects of nicotine on the healing of extraction sockets in rats. A histological study. Br Dent J. 2002; 13(1):3-9.

Poggi $\mathrm{P}$, Rota MT, Boratto $\mathrm{R}$. The volatile fraction of cigarette smoke induces alterations in the human gingival fibroblast cytoskeleton. J Periodon Res 2002; 37: 230-235.

Prado, R., Neves, L., Marcolino, A., et al. (2010). Effect of low-level laser therapy on malondialdehyde concentration in random cutaneous flap viability. Photomed. Laser Surg. 28, 379-384.

Prado, R.P., Liebano, R.E., Hochman, B.S., Pinfildi, C.E., and Ferreira, L.M. (2006). Experimetal model for level laser therapy on ischemic random skin flap in rats. Acta Cir. Bras. 21, 258-262.

Prado, R.P., Pinfildi, C.E., Liebano, R.E., Rochman, B.S., and Ferreira, L.M. (2009). Effect of application site of low-level laser therapy in random cutaneous flap viability in rats. Photomed. Laser Surg. 27, 411-416.

Ramp WK, Lenz LG, Galvin RJ. Nicotine inhibits collagen synthesis and alkaline phosphatase activity, but simulates DNA synthesis in osteoblast-like cells. Proc Soc Exp Biol Med. 1988; 197(1):36 -43.

Ribeiro LNS. Avaliação da Remodelação Óssea em alvéolos dentários, após a aplicação do Laser de Baixa Potência. 2013. 120 p. Dissertação de Mestrado, Faculdade de Odontologia de Ribeirão Preto/USP.

Roach HI. Why does bone matrix contain non-collagenous proteins? The possible roles of osteocalcin, osteonectin, osteopontin and bone sialoprotein in boné mineralisation and resorption. Cell Biol Int. 1994 18:617-28.

Rota MT, Poggi P, Boratto R. Human gingival fibroblast cytoskeleton is a target for volatile smoke components. J Periodontol 2001; 72: 709-713.

Rothem DE, Rothem L, Dahan A, Eliakim R, Soudry M. Nicotinic modulation of gene expression in osteoblast cells, MG-63. Bone 2011;48(4):903-9.

Saito S, Shimizu N. Stimulatory effects of low-power laser irradiation on bone regeneration in midpalatal suture during expansion in the rat. Am J Orthod Dentofacial Orthop 1997 May;111(5):525-32.

Saito CT, Gulinelli JL, Panzarini SR, Garcia VG, Okamoto R, Okamoto T, Sonoda CK, Poi WR. Effect of low-level laser therapy on the healing process after tooth replantation: a 
histomorphometrical and immunohistochemical analysis. Dent Traumatol. 2011 Feb;27(1):30-9.

Saldanha JB, Pimentel SP, Casati MZ, et al.; Guided bone regeneration may be negatively influenced by nicotine administration: A histologic study in dogs. J Periodontol 2004: 75: 565.

Sambrook J, Russell DW. Quantitative PCR. CSH Protoc. 2006; 2006(1): pii: pdb.prot3842.

Sambrook, J.; Russell, D. W. Molecular Cloning: A Laboratory Manual. 3rd. New York, United States of America: Cold Spring Harbor Laboratory Press, 2001.

Santiago HA, Zamarioli A, Sousa Neto MD, Volpon JB. Exposure to secondhand smoke impairs fracture healing in rats. Clin Orthop Relat Res. 2017; 475(3):894-902.

Sella VR1, do Bomfim FR, Machado PC, da Silva Morsoleto MJ, Chohfi M, Plapler H. Effect of low-level laser therapy on bone repair: a randomized controlled experimental study. Lasers Med Sci. 2015 Apr;30(3):1061-8.

Sherwin MA, Gastwirth CM. Detrimental effects of cigarette smoking on lower extremity wound healing. J Foot Surg 1990 Jan;29(1):84-7.

Shin SH , Kim KH , Choi NR, Kim IR , Park BS, Kim YD , Kim UK , Kim CH Efeito da terapia a laser de baixo nível em osteoblastos tratados com bisfosfonato. Maxillofac Plast Reconstr Surg. 201625 de novembro; 38 (1): 48.

Silverstein P. Smoking and wound healing. Am J Med 1992;93:22-24.

Stampli MR, Anderson GP. How cigarette smoke skews immune responses to promote infection, lung disease and cancer. Nat Rev Immunol. 2009; 9:377-84.

Stein A, Benayahu D, Maltz L, Oron U. Low-level laser irradiation promotes proliferation and differentiation of human osteoblasts in vitro. Photomed Laser Surg. 2005 Apr;23(2):161-6.

Takeda Y. Irradiation effect of low-energy laser on alveolar bone after tooth extraction. Experimental study in rats. Int J Oral Maxillofac Surg 1988 Dec;17(6):388-91.

Tanabe N, Wheal BD, Kwon J, Chen HH, Shugg RP, Sims SM, Goldberg HA, Dixon SJ. Osteopontin signals through calcium and nuclear factor of activated T cells (NFAT) in osteoclasts: a novel RGD-dependent pathway promoting cell survival. J Biol Chem. 2011; 286(46):39871-81.

Tanaka H, Tanabe N, Suzuki N, Shoji M, Torigoe H, Sugaya A. Nicotine affects mineralized nodule formation by the human osteosarcoma cell line Saos-2. Life Sci 2005;77:2273-84.

Tanaka S, Matsuzaka K, Sato D, Inoue T. Characteristics of newly formed bone during guided bone regeneration: analysis of cbfa-1, osteocalcin, and VEGF expression. $J$ Oral Implantol. 2007; 33:321-6.

Terai K, Takano-Yamamoto T, Ohba Y, Hiura K, Sugimoto M, Sato M, Kawahata H, Inaguma $\mathrm{N}$, Kitamura Y, Nomura S. Role of osteopontin in bone remodeling caused by mechanical stress. J Bone Miner Res. 1999; 14:839-49.

Tim CR, Bossini PS, Kido HW, Malavazi I, von Zeska Kress MR, Carazzolle MF, Parizotto NA, Rennó AC. Effects of low-level laser therapy on the expression of osteogenic genes during the initial stages of bone healing in rats: a microarray analysis. Lasers Med Sci. 2015 Dec;30(9):2325-33. 
Theiss SM, Boden SD, Hair G, Titus L, Morone MA, Ugbo J. The effect of nicotine on gene expression during spine fusion. Spine 2000;25(20):2588-94.

Tipton DA, Dabbous MK. Effects of nicotine on proliferation and extracellular matrix production of human gingival fibroblasts in vitro. J. Periodontol. 66 (12): 1056-64, 1995.

Torricelli P, Giavaresi G, Fini M, Guzzardella GA, Morrone G, Carpi A, Giardino R. Laser biostimulation of cartilage: in vitro evaluation. Biomed Pharmacother 2001 Mar; 55(2): $117-$ 20.

Trelles MA, Mayayo E. Bone fracture consolidates faster with low-power laser. Lasers Surg Med 1987; 7(1): 36-45.

Ueda Y, Shimizu N. Effects of pulse frequency of low-level laser therapy (LLLT) on bone nodule formation in rat calvarial cells. J Clin Laser Med Surg 2003 Oct;21(5):271-7.

Ward KD, Klesges RC. A meta-analysis of the effects of cigarette smoking on bone mineral density. Calcif Tissue Int. 2001; 68(5):259-70.

Wong PK, Christie JJ, Wark JD. The effects of smoking on bone health. Clin Sci. 2007; 113:233-41.

Yamano S1, Berley JA, Kuo WP, Gallucci GO, Weber HP, Sukotjo C. Effects of nicotine on gene expression and osseointegration in rats. Clin Oral Implants Res. 2010 Dec;21(12):1353-9.

Zheng LW, Ma L, Cheung LK. Changes in blood perfusion and bone healing induced by nicotine during distraction osteogenesis. Bone (2008).04.002. 
$\mathcal{A}_{\text {nexo }}$ 



\section{ANEXO 1 - COMITÊ DE ETICA EM PESQUISA}

UNIVERSIDADE DE SÁ PAULO
ONDE OE OOONTOLOOIA DE RIBERTO PRETO

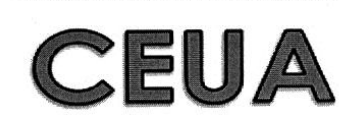

Comissão de Ética no Uso de Animais

\author{
Universidade de São Paulo \\ Faculdade de Odontologia de Ribeirão Preto \\ COMISSÃO dE ÉTICA NO USO DE ANIMAIS
}

\section{Certificado CeUA - FORP/USP}

Certificamos que o Protocolo $n^{\circ} 2013.1 .970 .58 .6$ sobre a pesquisa intitulada "Influência da inalação da fumaça de cigarro sobre remodelação óssea após a disjunção palatina em ratos", sob a responsabilidade da Profa. Dra. Maria Bernardete Sasso Stuani, está de acordo com os Princípios Éticos na Experimentação Animal adotados pela Comissão de Ética no Uso de Animais da Faculdade de Odontologia de Ribeirão Preto, USP, APROVADO em reunião da CEUA de 16/10/2013 (60 animais), com alterações aprovadas em reunião da CEUA de 29/04/2015 (totalizando 85 animais).

We hereby certify that the protocol $n^{\circ} 2013.1 .970 .58 .6$ regarding the research entitled "Effects of cigarrete smoking in the bone healing after rapid maxillary expansion, in rats", under the responsibility of Profa. Dra. Maria Bernardete Sasso Stuani, is in accordance with the Ethical principles in animal research adopted by the Animal Research Ethics Committee of the School of Dentistry of Ribeirão Preto, University of São Paulo, Brazil, was approved in 16/10/2013 (60 animals), with changes approved in 29/04/2015 (totalizing 85 animals).

Ribeirão Preto, 29 de abril de 2015.

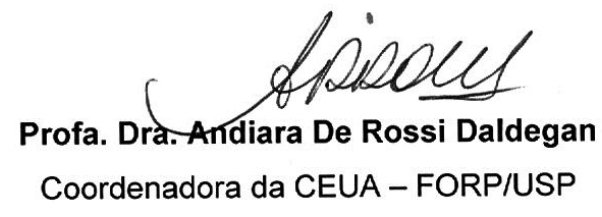

